\author{
UNIVERSIDADE DE SÃO PAULO \\ ESCOLA DE ENGENHARIA DE SÃO CARLOS
}

CYNTHIA AKEMI ANNO FRANCO

Participação pública na Avaliação de Impacto Ambiental de projetos no estado de São Paulo

São Carlos

2021 


\section{Participação pública na Avaliação de Impacto Ambiental de projetos no} estado de São Paulo

\section{Versão Corrigida}

Dissertação apresentada à Escola de Engenharia de São Carlos da Universidade de São Paulo, como requisito para a obtenção do Título de Mestre em Ciências da Engenharia ambiental.

Área de Concentração: Engenharia Ambiental

Orientador: Prof. ${ }^{\text {a }}$ Dr. ${ }^{\text {a }}$ Maria Rita Raimundo e Almeida 
AUTORIZO A REPRODUÇÃO TOTAL OU PARCIAL DESTE TRABALHO, POR QUALQUER MEIO ÇONVENCIONAL OU ELETRÔNICO, PARA FINS DE ESTUDO E PESQUISA, DESDE QUE CITADA A FONTE.

Ficha catalográfica elaborada pela Biblioteca Prof. Dr. Sérgio Rodrigues Fontes da EESC/USP com os dados inseridos pelo(a) autor(a).

Franco, Cynthia Akemi Anno
F825p Participação pública na avaliação de impacto ambiental de projetos no estado de São Paulo / Cynthia Akemi Anno Franco; orientadora Maria Rita Raimundo e Almeida. São Carlos, 2021.

Dissertação (Mestrado) - Programa de Pós-Graduação e Área de Concentração em Ciências da Engenharia Ambiental -- Escola de Engenharia de São Carlos da Universidade de São Paulo, 2021.

1. AIA. 2. Audiência pública. 3. Licenciamento ambiental. 4. Processo participativo. 5. Rodoanel. I. Título.

Eduardo Graziosi Silva - CRB - 8/8907 


\section{FOLHA DE JULOAMENTO}

Candidata: Bacharela CYNTHIA AKEMI ANNO FANCO.

Título da dissertação: "Participação pública no avaliação de impacto ambiental de projetos no estado de São Paulo".

Data da defesa: 10/02/2021.

Comissāo Julgadora

Profa. Dra. Maria Rita Raimundo e Almeica

(Orientadora)

(Universidade Federal de Itajubá/UNIFEI)

Prof. Dr. Severino Soares Agra Filho

(Universidade Federal da Bahia/UFBA)

Prof. Dr. Paulo Santos de Almeida

(Escola de Artes, Ciências e Humanidades/EACH-USP)

\section{Resultado}
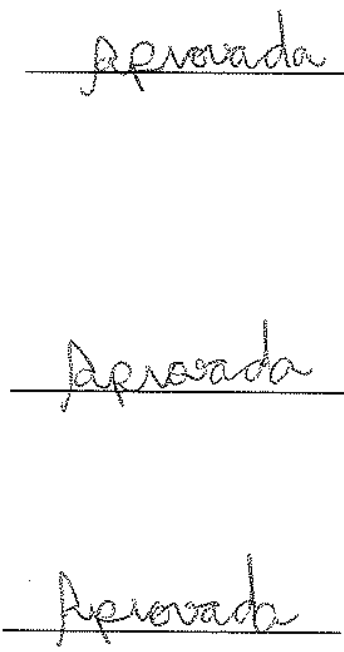

Coordenador do Programa de Pós-Graduação em Ciências da

Engenharia Ambiental:

Prof. Associado Frederico Fabio Maudo

Presidente da Comissão de Pós-Graduação:

Prof. Titular Murilo Araujo Romero 
À minha filha Luiza. 


\section{AGRADECIMENTOS}

À Professora Maria Rita, por me guiar neste percurso acadêmico, por todo o suporte no desenvolvimento deste trabalho e também por todo apoio emocional. Sua orientação e toda a experiência envolvida nesta pesquisa me transformaram como profissional e como pessoa.

À minha mãe Ivete, seu amor infinito e seus cuidados tornaram este sonho realidade.

Ao meu pai Celio, por sempre me mostrar o valor dos estudos e da ciência.

À minha irmã Larissa, por sua paciência e acolhimento nos momentos em que tudo parecia estar perdido, seu incansável apoio durante esta trajetória foi essencial para que eu chegasse até aqui.

Ao meu companheiro de vida Guilherme, por ser o alicerce da nossa família, por sempre me fazer rir e por sempre me lembrar da força que existe dentro de mim.

À minha filha Luiza, com todo o amor deste mundo, por ter sido sempre tão companheira e tão compreensiva comigo durante a elaboração deste trabalho.

À minha madrinha Regina, por me ajudar tanto e por estar sempre presente desde o meu primeiro dia de vida.

Às minhas amigas, Letícia, Rafaela, Camila, Jéssica e Helena, irmãs de alma, por sempre acreditarem em mim e por me encorajarem a seguir em frente, sempre.

Aos amigos que a participação pública uniu e que levarei por toda vida, agradeço por todas as conversas, discussões, trocas e pelo ombro amigo nos momentos mais difíceis.

Aos colegas do NEPA, por todo conhecimento compartilhado que ajudaram a ampliar minha visão sobre as políticas públicas ambientais.

A todos os profissionais que contribuíram para o desenvolvimento deste trabalho, aos que se dedicaram a responder minha pesquisa preliminar, aos técnicos da CETESB que me auxiliaram na coleta de dados dos processos e àqueles que cederam seu tempo e expertise para realização das entrevistas.

Ao Nelson e ao José da secretaria do PPGSEA-USP, por todo o suporte oferecido nestes anos que estive no mestrado.

À Coordenação de Aperfeiçoamento de Pessoal de Nível Superior (CAPES), por viabilizar o apoio financeiro a este trabalho. 
“O futuro apresenta-se quase sempre diverso daquilo que pensávamos. O passado também era diferente, de modo que, no todo, ambos têm menor importância do que parecem. Pois a distância, que diminui os objetos para o olho, engrandece-os para o pensamento. Só o presente é verdadeiro e real; ele é o tempo realmente preenchido e é nele que repousa exclusivamente a nossa existência”. 


\section{RESUMO}

FRANCO, C. A. A. Participação pública na Avaliação de Impacto Ambiental do estado de São Paulo. 2021. Dissertação (Mestrado) - Escola de Engenharia de São Carlos, Universidade de São Paulo, São Carlos, 2021.

Na Avaliação de Impacto Ambiental (AIA) é essencial que seja incorporada a participação do público para que aconteça uma distribuição mais equitativa do poder. Este estudo se fundamenta na importância de entender como se estabelecem as relações entre as dimensões governamentais, coorporativas e sociais envolvidas em um processo de AIA, de compreender como a sociedade pode participar e identificar o que o faz ser, de fato, participativo. $\mathrm{O}$ objetivo desta pesquisa é descrever e analisar a participação pública no processo de licenciamento ambiental com AIA do estado de São Paulo, utilizando como estudo de caso processos considerados participativos pelas partes envolvidas, sendo selecionados os processos dos quatro trechos do Rodoanel Mário Covas até a emissão da licença prévia. A metodologia deste trabalho foi dividida em duas etapas. Na primeira, foi utilizada uma pesquisa survey para definir os estudos de caso e para identificar percepções do que é um caso participativo. A partir disso, foi selecionado o caso do Rodoanel. A segunda etapa da metodologia contemplou análise documental para os processos de licenciamento com AIA do caso selecionado, realização de entrevista semiestruturada com atores envolvidos nos processos e análise de conteúdo. Quando pertinente, também utilizou-se o software IRAMUTEQ para análise textual baseado em estatísticas. Os resultados obtidos apontaram que o processo de AIA do Rodoanel foi considerado participativo por levantar questionamentos acerca da justificativa do empreendimento, da concepção do projeto e dos impactos ambientais e urbanísticos decorrentes da sua implantação e, com isso, envolver diferentes atores e apresentar mobilização social organizada pelos interessados no processo. A participação pública ocorreu, principalmente, no envolvimento do Conselho Estadual de Meio Ambiente (CONSEMA), nas manifestações por escrito dos interessados, na publicidade das informações, na consulta a outros órgãos ligados ao processo e nas audiências públicas. A percepção dos atores do processo de AIA sobre a participação pública demonstrou uma forte associação com o momento das audiências públicas. Os atores entrevistados consideraram que o processo de AIA do estado de São Paulo é bom sob o aspecto da participação, sendo que a mesma é importante, mas que ainda existe muito a ser melhorado. Com a realização desta pesquisa foi possível compreender os momentos e os motivos pelos 
quais um processo de AIA é considerado participativo, a percepção de atores sobre a participação pública e identificar possíveis melhorias para envolver o público durante um processo de AIA.

Palavras-chave: AIA. Audiência pública. Licenciamento ambiental. Processo participativo. Rodoanel. 


\begin{abstract}
FRANCO, C. A. A. Public participation in Environmental Impact Assessment of São

Paulo state. 2021. Dissertation (Master) - São Carlos School of Engineering, University of São Paulo, São Carlos, 2021.
\end{abstract}

In Environmental Impact Assessment (EIA), the public participation must be incorporated to achieve a more equitable distribution of power. This study is based on the importance of understanding how the relationships between governmental, corporate, and social dimensions involved in an EIA process are established, of understanding how society can participate, and identifying what makes it, in fact, participatory. The objective of this research is to describe and analyze the public participation in EIA process of São Paulo state. The case study was process considered participatory by stakeholders, and the selected one was the Mário Covas Ring Road. The analysis considered the processes until the issuance of the preliminary license. The methodology of this work was divided into two stages. In the first, a survey was used to define the case studies and to identify perceptions of what a participatory case is. From this, the case of the Ring Road was selected. The second stage of the methodology included documentary analysis for the licensing processes with EIA of the selected case, a semi-structured interview with stakeholders involved in the processes, and content analysis. When relevant, the IRAMUTEQ software was also used for textual analysis based on statistics. The results obtained pointed out that the EIA process of the Ring Road was considered participatory because it raised controversies about the justification of the project, the design of the project, about the environmental and urban impacts resulting from its implementation, for involving different actors and for presenting social mobilization organized by the interested parties. In the process, public participation occurred mainly in the involvement of the Environmental State Council (CONSEMA), in the written manifestations of stakeholders, in the publicity of information, in consultation with other bodies linked to the process, and in public hearings. The perception of the stakeholders in the EIA process about public participation demonstrated a strong association with the timing of public hearings. The stakeholders interviewed considered that the EIA process in São Paulo state is good and that participation is essential, but that there is still much to be improved. With this research, it was possible to understand the moments and reasons why an EIA process is considered participatory, the perception of stakeholders about public participation, and to identify possible improvements to involve the public during an EIA process. 
Key-words: EIA. Public hearing. Environmental licensing. Participatory process. Rodoanel. 


\section{LISTA DE FIGURAS}

Figura 1 - Processo administrativo do Licenciamento Ambiental brasileiro.

Figura 2 - O processo de Avaliação de Impacto Ambiental vinculado ao Licenciamento

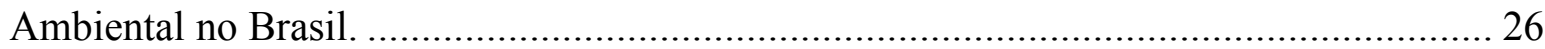

Figura 3 - Processo de Avaliação de Impacto Ambiental ............................................. 27

Figura 4 - Diagrama para determinar a necessidade de estudos ambientais..................... 28

Figura 5 - A escada da participação cidadã. ................................................................... 33

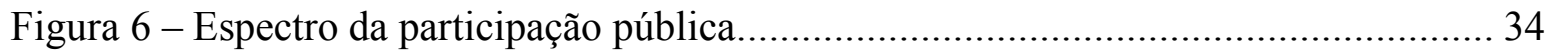

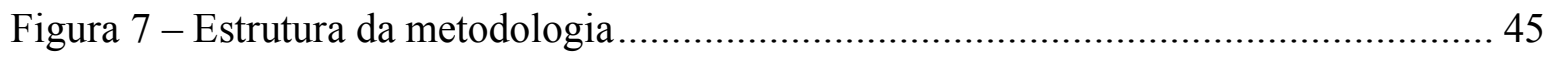

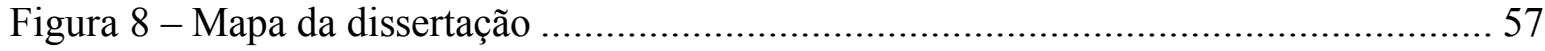

Figura 9 - Casos de Licenciamento Ambiental citados no questionamento preliminar...... 59

Figura 10 - Nuvem de palavras do questionamento preliminar: Por que você considera que a participação neste processo foi notória?.

Figura 11 - Mapa dos atores envolvidos nos processos de Licenciamento com AIA dos quatro trechos do Rodoanel

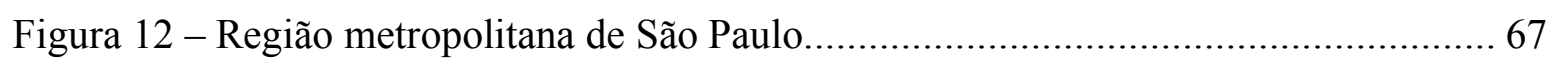

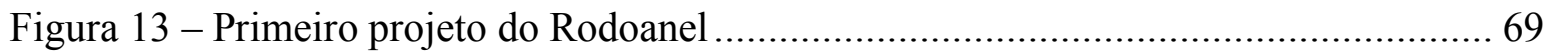

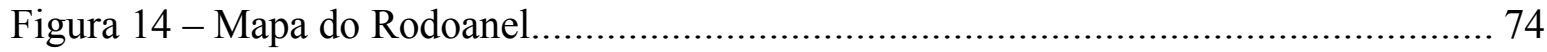

Figura 15 - Nuvem de palavras sobre a percepção da participação na AIA dos atores do

Rodoanel 


\section{LISTA DE TABELAS}

Tabela 1 - Princípios básicos de boas práticas da participação pública na AI.................... 37

Tabela 2 - Formas de participação na Avaliação de Impacto Ambiental .......................... 38

Tabela 3 - Objetivos da participação nas etapas da Avaliação de Impacto Ambiental....... 38

Tabela 4 - Perguntas do questionamento preliminar ..................................................... 47

Tabela 5 - Registro das respostas do questionamento preliminar .................................. 47

Tabela 6 - Análise da Pergunta 1 do questionamento preliminar ..................................... 48

Tabela 7 - Quadro para mapeamento dos atores ........................................................ 52

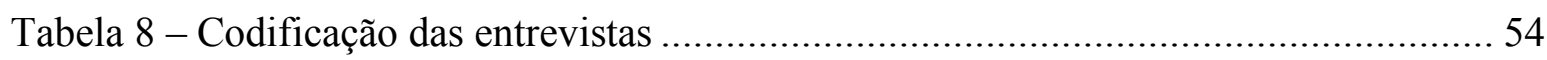

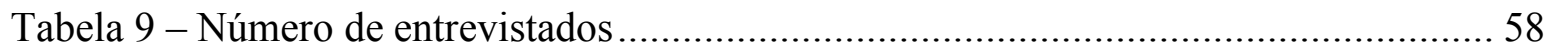

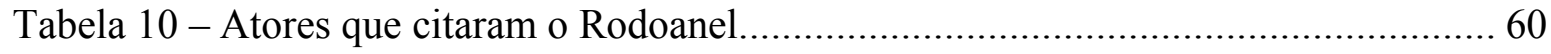

Tabela 11 - Quantidade de atores mapeados e entrevistados ....................................... 65

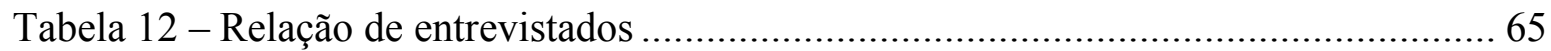

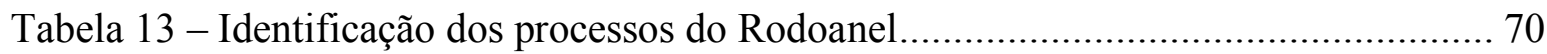

Tabela 14 - Momentos de participação no processo de Licenciamento com AIA do estado de São Paulo, de acordo com os volumes analisados 84 


\section{LISTA DE ABREVIATURAS E SIGLAS}

AAE - Avaliação Ambiental Estratégica

AI - Avaliação de Impacto

AIA - Avaliação de Impacto Ambiental

CBAI - Congresso Brasileiro de Avaliação de Impacto

CETESB - Companhia Ambiental do Estado de São Paulo

CIR - Centro de Informações do Rodoanel

CONAMA - Conselho Nacional de Meio Ambiente

CONDEPHAAT - Conselho de Defesa do Patrimônio Histórico, Arqueológico, Artístico e

Turístico do Estado

CONSEMA - Conselho Estadual de Meio Ambiente

CPTM - Companhia Paulista de Trens Metropolitanos

DAIA - Departamento de Avaliação de Impacto Ambiental

DER - Departamento de Estadas de Rodagem

DERSA - Desenvolvimento Rodoviário S/A

EIA - Estudo de Impacto Ambiental

EMPLASA - Empresa Paulista de Planejamento Metropolitano S/A

FAU - Faculdade de Arquitetura e Urbanismo

FEPASA - Ferrovia Paulista S/A

FESPSP - Fundação Escola de Sociologia e Política do Estado de São Paulo

FF - Fundação Florestal

FUNAI - Fundação Nacional do Índio

IAIA - International Association for Impact Assessment

IAP2 - International Association for Public Participation

IB - Instituto Biológico

IBAMA - Instituto Brasileiro do Meio Ambiente e dos Recursos Naturais Renováveis

IBGE - Instituto Brasileiro de Geografia e Estatística

IF - Instituto Florestal

IPHAN - Instituto do Patrimônio Histórico e Artístico Nacional

IPT - Instituto de Pesquisas Tecnológicas

IRAMUTEQ - Interface de $R$ pour les Analyses Multidimensionnelles de Textes et de Questionnaires

LABHAB - Laboratório de Habitação e Assentamentos Humanos 
LC - Lei Complementar

LP - Licença Prévia

LI - Licença de Instalação

LO - Licença de Operação

MP - Ministério Público

MPF - Ministério Público Federal

MPSP - Ministério Público do Estado de São Paulo

NIMBY - "Not In My Backyard"

OCDE - Organização para Cooperação do Desenvolvimento Econômico

ONG - Organização Não Governamental

ONU - Organização das Nações Unidas

PNMA - Política Nacional do Meio Ambiente

PNUA - Programa das Nações Unidas para o Ambiente

RAP - Relatório Ambiental Preliminar

RIMA - Relatório de Impacto Ambiental

RMSP - Região Metropolitana de São Paulo

SEAQUA - Sistema Estadual de Administração da Qualidade Ambiental, Proteção, Controle

e Desenvolvimento do Meio Ambiente e Uso Adequado dos Recursos Naturais de São Paulo

SMA - Secretaria Estadual do Meio Ambiente

STM - Secretaria de Estado dos Transportes Metropolitanos

TR - Termo de Referência

UNECE - United Nations Economic Commission for Europe

UNEP - United Nations Environmental Programme

USP - Universidade de São Paulo

ZEE - Zoneamento Ecológico Econômico 


\section{SUMÁRIO}

1. INTRODUÇÃO E JUSTIFICATIVA ............................................................. 18

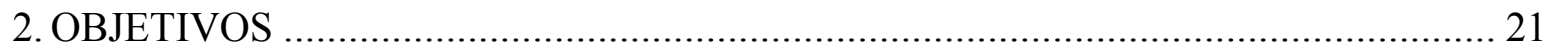

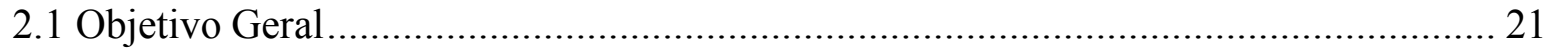

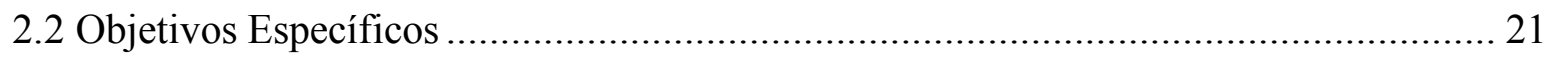

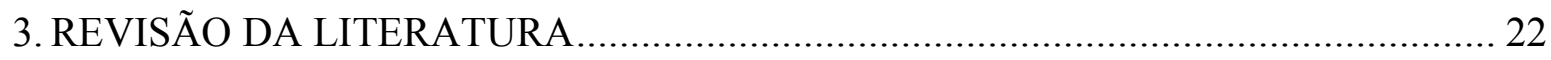

3.1 Conceito e histórico da Avaliação de Impacto Ambiental ........................................ 22

3.2 Avaliação de Impacto Ambiental e Licenciamento Ambiental no Brasil ..................... 23

3.3 O processo de Avaliação de Impacto Ambiental ........................................................ 26

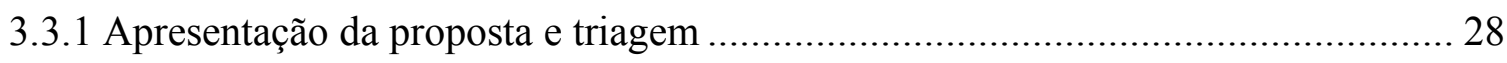

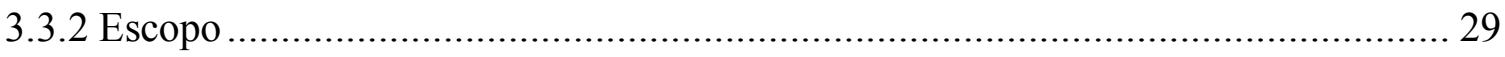

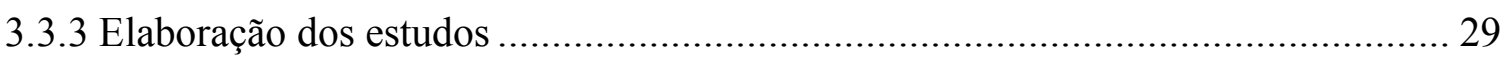

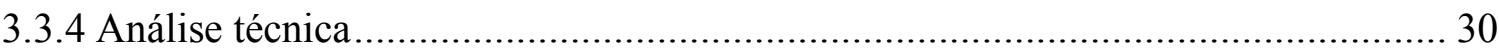

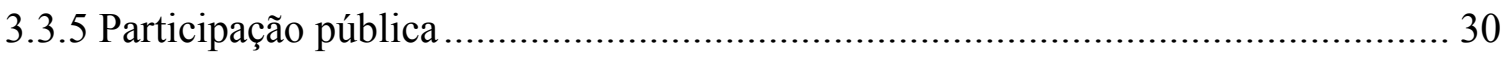

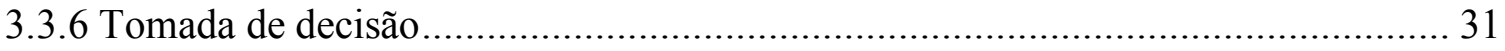

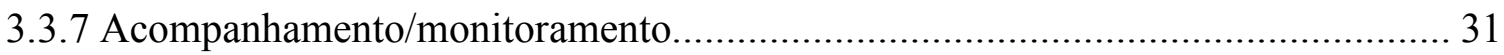

3.4 Origem da participação pública nas questões ambientais........................................ 32

3.5 Participação pública na Avaliação de Impacto Ambiental ............................................ 36

3.6 Caracterização da participação pública no processo de AIA paulista ........................... 41

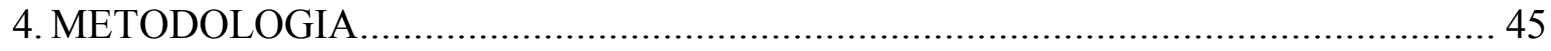

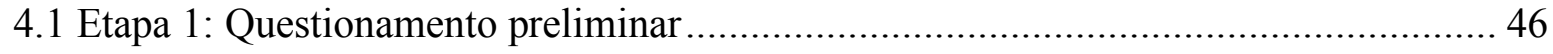

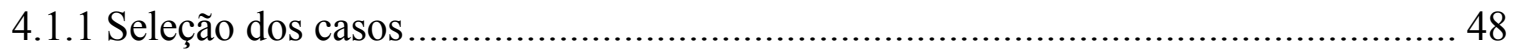

4.1.2 Percepções da participação pública ............................................................. 49

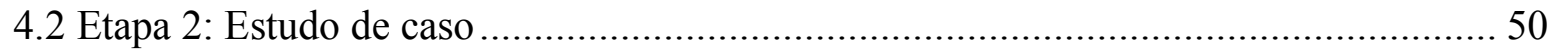

4.2.1 Análise documental e mapeamento de atores................................................ 51

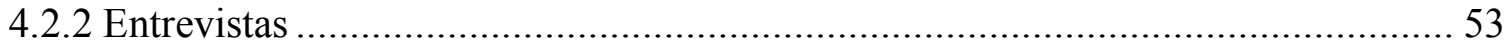

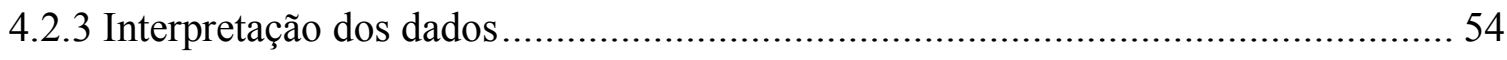

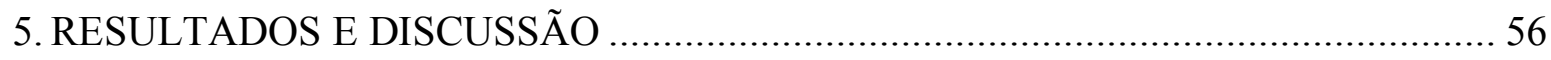

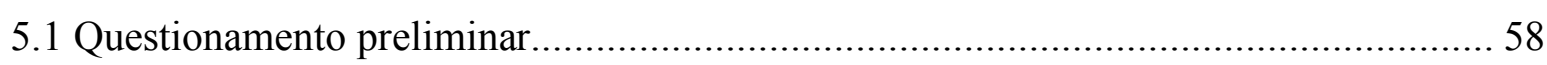

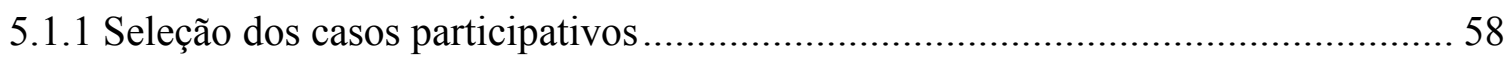

5.1.2 Percepções da participação pública .............................................................. 61

5.2 Mapeamento das partes interessadas do Rodoanel ............................................... 62

5.3 O processo de AIA do Rodoanel e a participação..................................................... 66

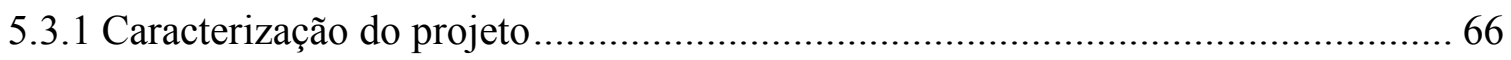




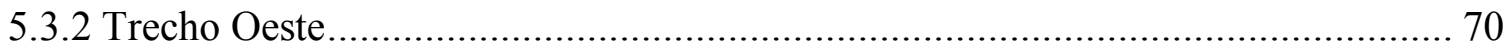

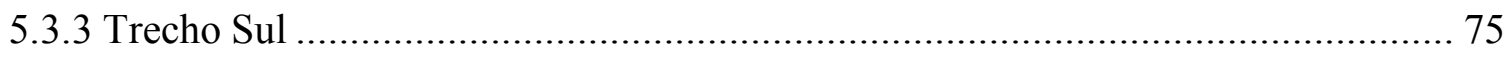

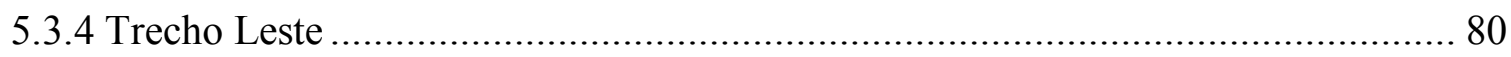

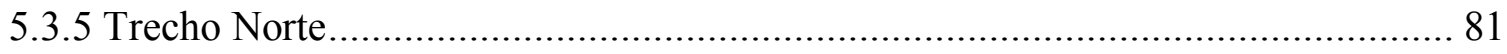

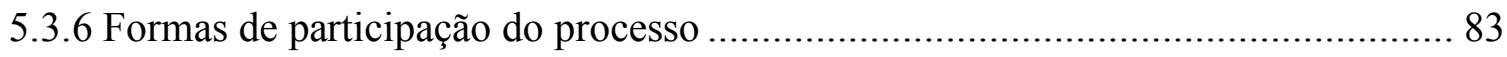

5.4 Percepção dos entrevistados sobre a participação na AIA ........................................... 90

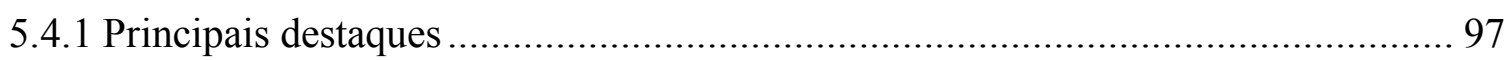

5.4.2 Sugestões de melhorias para a participação na prática ...................................... 99

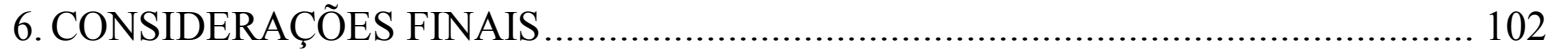

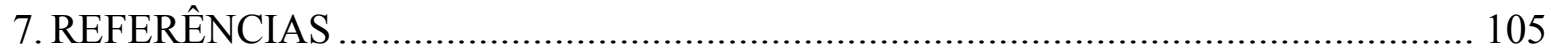

APÊNDICE A - Roteiro da entrevista semiestruturada............................................... 114

ANEXO A - Termo de Consentimento Livre e Esclarecido (TCLE) ............................ 115 


\section{INTRODUÇÃO E JUSTIFICATIVA}

As relações entre a sociedade e o meio ambiente têm sido objeto de ampla discussão no que diz respeito ao desenvolvimento sustentável. Para que as interações entre as dimensões econômica, ecológica e social aconteçam de maneira equilibrada, foram instituídos os instrumentos de política ambiental (BRASIL, 1981).

Entre os avanços para o desenvolvimento sustentável brasileiro está a Constituição Federal de 1988, que traz em sua redação a importância da transparência e da publicidade de dados e outros atos da administração pública e incorpora um capítulo tratando do meio ambiente e dispõe em seu artigo 225: "Todos têm direito ao meio ambiente ecologicamente equilibrado, bem de uso comum do povo e essencial à sadia qualidade de vida, impondo-se ao poder público e à coletividade o dever de defendê-lo e preservá-lo para as presentes e futuras gerações" (BRASIL, 1988).

Assim, as normas ambientais têm servido como diretrizes para a atuação do poder público junto às empresas e junto à população e também como ferramentas na busca da sustentabilidade, por garantirem segurança jurídica. Algumas destas normas instituíram instrumentos de política ambiental que têm por objetivo o controle de atividades humanas potencialmente poluidoras e, quando bem aplicados, asseguram que estas atividades causem o menor impacto ambiental possível no meio. A Avaliação de Impacto Ambiental (AIA) é um deles, e tem como objetivo verificar se projetos de empreendimentos são viáveis ambientalmente e gerenciar seus impactos.

Quando as iniciativas para o desenvolvimento de projetos consideram os impactos econômicos, ecológicos e humanos, geram um estímulo para que a participação do público seja incorporada na AIA (FITZPATRICK; SINCLAIR, 2003). A importância deste envolvimento deriva das questões que estão em jogo quando se trata de projetos que possam causar impactos significativos, como da obrigação de fornecer informações sobre os impactos ambientais de uma proposta (GLASSON, 2012) e de levar em consideração diferentes opiniões e pontos de vista do público para que uma melhor decisão com relação ao processo seja tomada (SÁNCHEZ, 2013).

Quando bem feita, a participação do público pode tornar a tomada de decisões mais democrática, gerando debates necessários para compreender problemas e buscar soluções (MARTIN, 2007). Ela também pode conduzir a melhores resultados em termos de qualidade ambiental e outros objetivos sociais, aumentando a confiança e a compreensão entre as partes (DIETZ; STERN, 2008). 
Parece haver um amplo consenso sobre a importância da participação do público para a tomada de decisões na AIA (LEE; ABBOT, 2003; GLUCKER et al., 2013) e seus benefícios foram claramente descritos em termos teóricos e práticos, mas o design e implementação prática de mecanismos participativos permanecem controversos (O'FAIRCHEALLAIGH, 2010).

A prática da AIA em todo o mundo sugere que a influência da participação pública nas decisões ainda é fraca, particularmente nos países em desenvolvimento (NADEEM; FISCHER, 2011). Quando os procedimentos ambientais não incluem adequadamente as partes afetadas na tomada de decisões, particularmente os setores vulneráveis e marginalizados da sociedade, a justiça ambiental não pode ser realizada (SIMPSON; BASTA, 2018).

O processo de AIA, as formas de participação e a tomada de decisão sobre um projeto dependem, em última análise, do órgão ambiental, pois é ele que realiza a comunicação com o público, recebe suas contribuições e as considera no processo (HOURDEQUIN et al., 2012). Logo, deve ser reconhecida pelas agências governamentais e outros organizadores dos processos como um requisito para uma ação eficaz e não como apenas um requerimento a cumprir durante a implementação de um projeto (SHEPHERD; BOWLER, 1997; DIETZ et al., 2008). Quando participação do público é realizada sem um planejamento prévio cuidadoso, sem recursos adequados e sem compromisso organizacional, os resultados podem ficar longe de atingir seu potencial (DIETZ; STERN, 2008).

Além da prática, a participação também enfrenta dificuldades na teoria. Desde os primeiros artigos publicados sobre a questão da participação, já era apontada a dificuldade dos estudiosos em definir seu significado (ARNSTEIN, 1969), revelando uma considerável confusão e desacordo sobre o que é a participação pública na AIA, sua amplitude e o que exige (GLUCKER et al., 2013; JOHNSON, 2020). A investigação sobre este tema tem ficado muito aquém das necessidades, com uma análise limitada das implicações de diferentes formas e graus de participação pública para a tomada de decisões na AIA (DIETZ; STERN, 2008; O'FAIRCHEALLAIGH, 2010).

A necessidade de pesquisas adicionais para avaliar a performance da participação pública na AIA são apresentadas pela literatura, como, por exemplo, a lacuna de estudos que identifiquem deficiências da prática atual e proponham medidas para melhorar sua efetividade (NADEEM; FISCHER, 2011), pesquisas empíricas sobre como os cidadãos pensam e atuam nos processos de AIA de modo a entender melhor sobre as possibilidades e limites da participação (WIKLUND, 2011), a necessidade de mais investigação sobre como 
os processos políticos influenciam a participação pública na AIA e como várias formas de participação pública se relacionam umas com as outras (O’FAIRCHEALLAIGH, 2010).

Então, este estudo se fundamenta na importância de entender as relações entre as dimensões governamentais, coorporativas e sociais envolvidas em um processo de AIA, de compreender como a sociedade pode participar de um processo e identificar o que o faz ser, de fato, participativo. O conhecimento da participação e suas formas, bem como das dificuldades encontradas para colocá-la em prática e demais informações a ela relacionadas, podem servir como contribuição para o aprimoramento dos momentos participativos de um processo de AIA.

Neste contexto, a questão orientadora da pesquisa foi como acontece a participação pública em processos considerados participativos na AIA do estado de São Paulo. De modo a responder esta pergunta, o objetivo desta pesquisa é descrever e analisar a participação pública no processo de Licenciamento Ambiental com Avaliação de Impacto Ambiental de empreendimentos do estado de São Paulo, a partir de estudos de caso considerados participativos pelos atores envolvidos. 


\section{OBJETIVOS}

\subsection{Objetivo Geral}

O objetivo deste estudo é descrever e analisar a participação pública no processo de Licenciamento Ambiental com Avaliação de Impacto Ambiental no estado de São Paulo.

\subsection{Objetivos Específicos}

a) Realizar um levantamento de processos de AIA de empreendimentos do estado de São Paulo considerados participativos pelos envolvidos no processo para selecionar os estudos de caso;

b) Identificar as percepções dos atores envolvidos sobre que é um processo participativo na AIA;

c) Descrever os mecanismos de participação pública na AIA no estado de São Paulo com base nos estudos de caso cujos processos foram considerados participativo;

d) Analisar os mecanismos de participação pública na AIA no estado de São Paulo com base nos estudos de caso e sugerir melhorias. 


\section{REVISÃO DA LITERATURA}

O presente capítulo apresenta a fundamentação teórica sobre os principais temas abordados para o desenvolvimento desta pesquisa. Desta forma, será abordado na primeira seção o conceito e um breve histórico da AIA, considerando o panorama internacional. Em seguida, será contextualizado o licenciamento ambiental brasileiro em nível federal e sua conexão com o processo de AIA. Na terceira seção, será contemplada uma descrição do processo de AIA. Na quarta, será apresentado um breve histórico da participação pública e sua origem nas questões ambientais. Na quinta, será mostrado o que a literatura científica referente à participação pública na AIA tem demonstrado com relação às boas práticas. Por fim, apresenta-se a caracterização da participação pública no processo de AIA paulista.

\subsection{Conceito e histórico da Avaliação de Impacto Ambiental}

A Avaliação de Impacto (AI) é definida como o processo de identificação das futuras consequências de uma ação atual ou proposta (IAIA, 2009). Já o termo "avaliação ambiental" pode ser entendido como uma técnica e um processo pelo qual as informações sobre os efeitos ambientais de um projeto são coletadas pelo desenvolvedor ou por outras fontes, e que são consideradas pela autoridade de planejamento na tomada de decisão sobre o desenvolvimento de um empreendimento (GLASSON, 2012).

Como uma união destes dois conceitos, a Avaliação de Impacto Ambiental (AIA) pode ser definida como o processo de identificação, previsão, avaliação e mitigação dos efeitos relevantes de propostas de desenvolvimento de empreendimentos, com o objetivo de analisar a viabilidade ambiental de projetos e fundamentar uma decisão a respeito (IAIA, 1999; SÁNCHEZ, 2013). A AIA é a forma mais antiga e institucionalizada de AI, tendendo a ser limitada a projetos de empreendimentos (LAWRENCE, 2013).

Apesar das questões sobre as ações humanas afetarem o meio ambiente serem antigas na história, a utilização contemporânea do termo Avaliação de Impacto Ambiental iniciou com a Política Ambiental Nacional dos Estados Unidos de 1969 (National Environmental Policy Act - NEPA) (ORTOLANO; SHEPHERD, 1995). Posteriormente, nas décadas de 1970 e 1980, muitos outros países começaram a introduzir a AIA em seu contexto, como Canadá, Austrália, China, Tailândia, Filipinas (FISCHER, 2014) e União Europeia (IAIA, 2009).

Um marco do processo de internacionalização da AIA foi a publicação de um documento, em 1985, pela Organização para Cooperação do Desenvolvimento Econômico (OCDE), que recomendava um modelo de processo de AIA para analisar os projetos e que acabou por fomentar programas de cooperação voltados especificamente ao fortalecimento 
da avaliação ambiental em países em desenvolvimento (SÁNCHEZ, 2013). Em 1989, o Banco Mundial passou a exigir que a AIA fosse realizada para grandes projetos financiados por ele e, no mesmo período, o Programa das Nações Unidas para o Ambiente (PNUA) também fez recomendações relativas ao estabelecimento de procedimentos de AIA para os Estados membros e para países em desenvolvimento (WOOD, 2003).

Um grande impulso para a difusão da AIA em nível internacional foram os tratados internacionais, em especial a Conferência das Nações Unidas sobre Ambiente e Desenvolvimento, realizada no Rio de Janeiro em 1992 (IAIA, 2009), que culminou na publicação do princípio 17 reconhecendo a importância da AIA:

A Avaliação de Impacto Ambiental, enquanto instrumento nacional, deve ser realizada para as atividades propostas que possam ter um impacto negativo significativo no ambiente e que estejam sujeitas a uma decisão de uma autoridade nacional competente (Conferência das Nações Unidas sobre Ambiente e Desenvolvimento, 1992).

No início dos anos 1990, houve um grande crescimento no número de regulamentos e diretrizes de AIA estabelecidos na América do Sul e, em 2005, pelo menos 120 países já possuíam algum sistema de AIA (GLASSON et al., 2005). Mais recentemente, Morgan (2012) relatou que 191 dos 193 membros das Nações Unidas têm legislação ou alguma norma que refira ao uso da AIA.

\subsection{Avaliação de Impacto Ambiental e Licenciamento Ambiental no Brasil}

Segundo Moreira (1989, p.57), "a exemplo do que ocorreu em outras regiões em desenvolvimento, as primeiras exigências de AIA na América Latina foram formuladas por agentes financeiros internacionais". Em consequência, a AIA teve suas primeiras aparições no Brasil na legislação do estado do Rio de Janeiro em 1975, e do estado de São Paulo em 1976; em nível federal, a primeira menção à AIA foi em uma lei promulgada em 1980, que tinha como objetivo estabelecer requisitos de zoneamento em "zonas críticas de poluição". No entanto, o apoio jurídico efetivo à AIA surgiu em 1981, com Política Nacional de Meio Ambiente (PNMA) (SÁNCHEZ, 2014), que estabeleceu a AIA como um de seus instrumentos (BRASIL, 1981). Desde então, a aplicação da AIA está associada ao Licenciamento Ambiental, fornecendo suporte para a análise das solicitações de licença

ambiental nos casos de projetos com potencial de causar efeitos significativos no ambiente (MONTAÑO; DE SOUZA, 2015; ALMEIDA; MONTAÑO, 2015). 
O vínculo entre o licenciamento e a AIA foi oficialmente estabelecido no país a partir da Resolução CONAMA n ${ }^{\circ} 01$ de 23 de janeiro 1986, que definiu os critérios básicos e diretrizes gerais para a AIA e que passou a exigir o Estudo de Impacto Ambiental (EIA) e seu respectivo Relatório de Impacto Ambiental (RIMA) para algumas tipologias de empreendimentos sujeitas ao Licenciamento Ambiental (CONAMA, 1986). Após, em 1988, a Constituição Federal em seu artigo 225 garantiu a todos o direito ao meio ambiente ecologicamente equilibrado incumbindo ao Poder Público:

$\S 1^{\circ}$. IV - exigir, na forma da lei, para instalação de obra ou atividade potencialmente causadora de significativa degradação do meio ambiente, estudo prévio de impacto ambiental, a que se dará publicidade (BRASIL, 1988).

Com a publicação da Resolução CONAMA no 237 de 1997, foram definidos os procedimentos e critérios utilizados para o licenciamento ambiental. O dispositivo também detalhou os empreendimentos e atividades sujeitas ao licenciamento, garantiu a publicidade aos EIAs/RIMAs e a realização de audiências públicas quando necessário (CONAMA, 1997).

O Licenciamento Ambiental tem como objetivo fornecer ou não a licença ambiental aos empreendimentos e atividades utilizadoras de recursos ambientais, consideradas efetiva ou potencialmente poluidoras ou daquelas que, sob qualquer forma, possam causar degradação ambiental (CONAMA, 1997). A licença ambiental é o documento em que o órgão ambiental estabelece condições, restrições e medidas de controle ambiental que devem ser seguidas pela empresa (CONAMA, 1997) e cabe ao órgão ambiental competente definir os critérios de exigibilidade, o detalhamento e a complementação levando em consideração as especificidades, os riscos ambientais, o porte e outras características do empreendimento ou atividade (CONAMA, 1986).

A prática institucionalizada do Licenciamento Ambiental pode ser dividida em três estágios nos quais os empreendedores são obrigados a solicitar: licença prévia (LP), licença de instalação (LI) e licença de operação (LO), a qual precisa ser renovada periodicamente (CONAMA, 1997; FONSECA; SÁNCHEZ; RIBEIRO, 2017). A LP é concedida na fase preliminar do planejamento do empreendimento ou atividade e tem como objetivo aprovar sua localização, concepção, viabilidade ambiental e estabelecer condicionantes para a próxima fase de implementação; a LI autoriza a instalação do empreendimento ou atividade de acordo com as especificações dos planos, programas, projetos, medidas de controle ambiental e condicionantes; já a LO tem como objetivo autorizar a operação após verificação do efetivo cumprimento das exigências feitas pelas licenças anteriores e estabelece medidas 
de controle ambiental e condicionantes para o funcionamento do empreendimento (CONAMA, 1997).

O Licenciamento Ambiental brasileiro pode, ainda, ser dividido em duas tipologias ou modalidades: o licenciamento simplificado e o licenciamento com AIA (Figura 1). O primeiro tipo abrange os empreendimentos que não causam impactos significativos. $\mathrm{O}$ segundo tipo se aplica a empreendimentos potencialmente causadores de impactos significativos, no qual o Licenciamento Ambiental necessita do auxílio da AIA para fornecer as informações que vão embasar a tomada de decisões governamentais com relação a viabilidade ambiental destes empreendimentos.

Figura 1 - Processo administrativo do Licenciamento Ambiental brasileiro

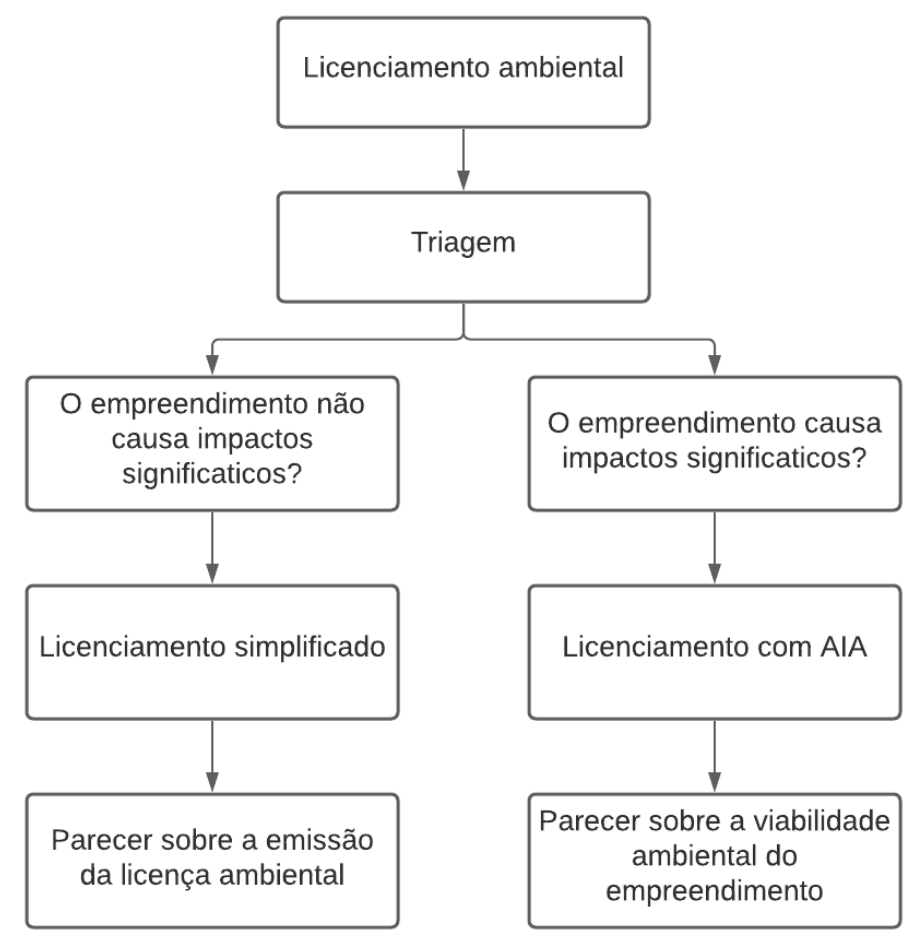

Fonte: Elaborado pela autora.

A AIA associada ao Licenciamento Ambiental na legislação brasileira impõe aos empreendedores privados e públicos novos requisitos para a planificação de projetos, alguns dos quais terão suas licenças negadas, ao passo que outras somente serão aceitas mediante modificações substanciais ou na dependência da aceitação de medidas mitigadoras e compensatórias (SÁNCHEZ, 2013).

O vínculo entre as etapas de AIA e os tipos de licença ambiental está demonstrado na Figura 2. 
Figura 2 - O processo de Avaliação de Impacto Ambiental vinculado ao Licenciamento Ambiental no Brasil.

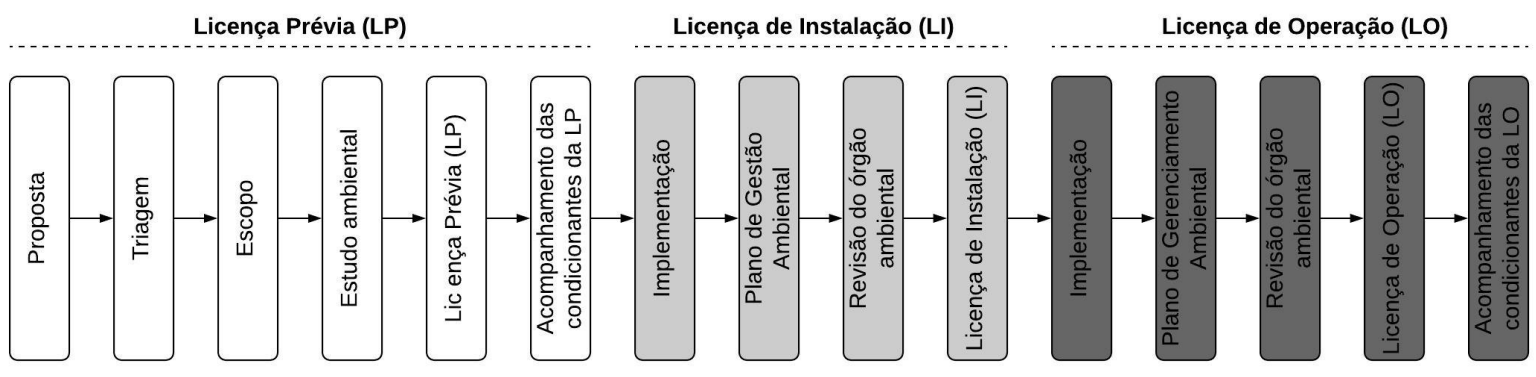

Fonte: Fonseca, Sánchez e Ribeiro (2017).

A competência do Licenciamento Ambiental, estabelecida com fragilidade legal pela Resolução CONAMA $n^{\circ}$ 237/1997, foi posteriormente e devidamente tratada pela Lei Complementar $\mathrm{n}^{\circ}$ 140/2011 que determinou o critério da abrangência do impacto, o critério da dominalidade exercida sobre determinado território (BRASIL, 2011; DE SOUZA, 2012) e regulamentou a competência comum dos três níveis de governo (municipal, estadual e federal) estabelecida na Constituição Federal de 1988, e outros instrumentos para regulamentar as relações institucionais. A autoridade competente pelo Licenciamento e, em consequência pela AIA, é sempre uma agência ambiental. No nível federal, o Instituto Brasileiro do Meio Ambiente e dos Recursos Naturais Renováveis (IBAMA) é responsável por projetos offshore, nucleares e outros, bem como aqueles que afetam dois ou mais estados, localizados em áreas administradas pelo governo federal e fronteiras internacionais próximas; os projetos com consequências regionais são geralmente avaliados por agências ambientais estaduais, enquanto outros, caracterizados pela importância local, podem ser avaliados pelos governos municipais (BRASIL, 2011; DUARTE et al., 2017a).

\subsection{O processo de Avaliação de Impacto Ambiental}

Como visto no capítulo anterior, quando um empreendimento ou atividade utilizadora de recursos naturais é considerado potencialmente causador de impactos significativos ao meio ambiente, este é obrigado a passar pelos procedimentos exigidos pela tipologia ou modalidade do Licenciamento Ambiental com AIA. A Avaliação de Impactos Ambientais auxilia a tomada de decisões, pois fornece uma análise sistemática das implicações ambientais de ações e alternativas de um projeto antes que uma decisão seja tomada, para que ela seja mais racional e estruturada (GLASSON; THERIVEL; CHADWI, 2005).

A AIA é um processo sistemático que examina antecipadamente as consequências ambientais das ações de desenvolvimento, visando a prevenção (GLASSON; THERIVEL; 
CHADWI, 2005). As principais etapas deste processo propostas por Sánchez (2013) estão demonstradas na Figura 3 e são: Apresentação da proposta de um projeto para análise do órgão ambiental; Triagem e enquadramento do projeto em categorias; Determinação do escopo do Estudo de Impacto Ambiental; Elaboração do estudo de Impacto Ambiental e do Relatório de Impacto Ambiental; Análise técnica do Estudo de Impacto Ambiental; Consulta pública; Decisão; e Acompanhamento e monitoramento (SÁNCHEZ, 2013).

Figura 3 - Processo de Avaliação de Impacto Ambiental

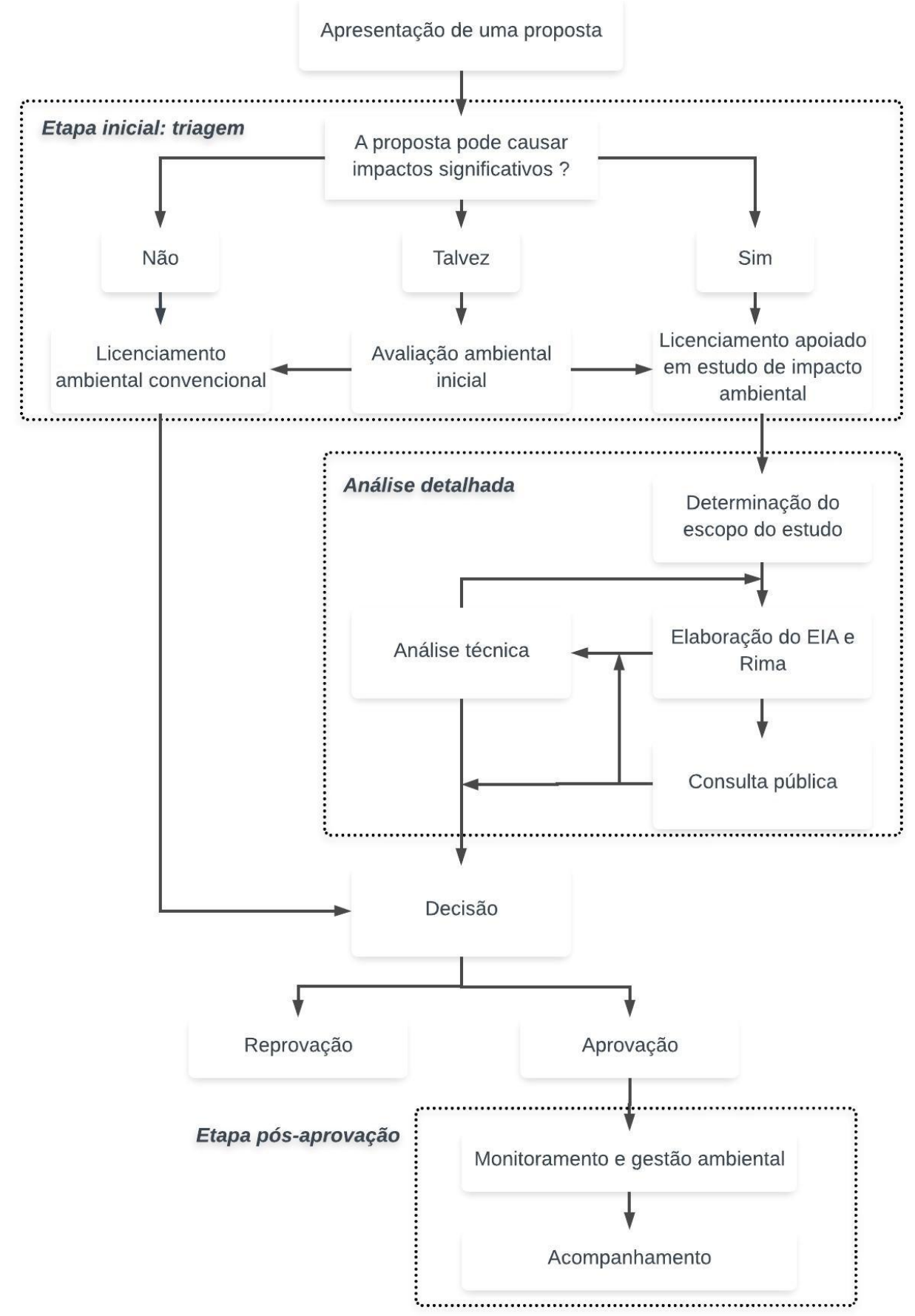

Fonte: SÁNCHEZ (2013). 


\subsubsection{Apresentação da proposta e triagem}

Ao dar início ao processo de AIA, a primeira etapa consiste na apresentação da proposta do projeto inicial de um determinado empreendimento ao órgão ambiental, contendo principalmente informações sobre o tipo de projeto e a sua localização. Em seguida, o órgão ambiental analisa o projeto e realiza a triagem e enquadramento com base na tipologia do empreendimento, porte, potencial poluidor e/ou localização (SÁNCHEZ, 2013).

A triagem, conhecida também pelo termo screening, é uma fase crítica de decisão no processo em que a autoridade competente determina se uma proposta de projeto tem potencial para causar impactos ambientais significativos e, consequentemente, se exigirá ou não AIA (WOOD; BECKER, 2005; WESTON, 2011). Para realização da triagem, são utilizadas diferentes técnicas que podem ser combinadas entre si e, geralmente, são divididas em quatro tipos: I) estudos preliminares ou avaliações ambientais iniciais, II) análise caso a caso, III) listas de projetos que se enquadram em AIA (positivas) ou que não se enquadram (negativas), e IV) limiares, que se baseia em medidas e limites específicos de acordo com o tamanho do projeto, localização e outras características (PINHO; MCCALLUM; CRUZ, 2010).

O diagrama da Figura 4 ilustra a resposta do meio ao confrontar a pressão imposta por um determinado projeto com a vulnerabilidade do ambiente em que é pretendido implantálo; logo, se o projeto implicar em uma alta pressão sobre um ambiente de alta vulnerabilidade, isso indicará um alto potencial de impactos significativos e, consequentemente, este projeto deverá passar pelo processo de AIA (SÁNCHEZ, 2013).

Após realizar o screening em uma fase inicial do processo, é possível decidir o tipo de estudo a ser realizado o mais rápido e o mais cedo possível, otimizando o processo e decisão sobre a autorização de uma proposta (ABAZA; BISSET; SADLER, 2004)

Figura 4 - Diagrama para determinar a necessidade de estudos ambientais.

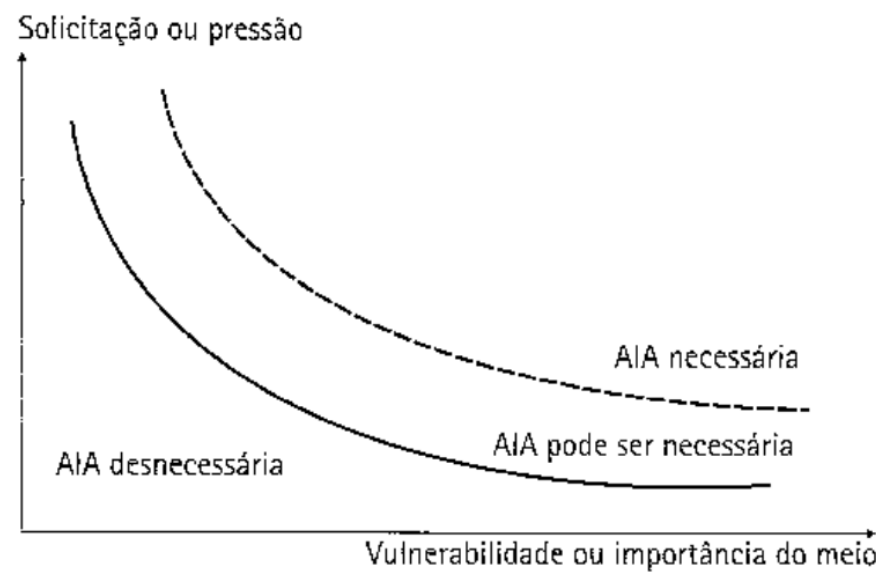

Fonte: Sánchez (2013). 


\subsubsection{Escopo}

Após a triagem e a definição da necessidade de AIA, o projeto passa pela fase de escopo realizada pelo órgão ambiental, que tem como objetivo identificar todos os possíveis impactos importantes, as questões cruciais e significativas para que seja estabelecido um termo de referência para elaboração do EIA daquele empreendimento (IAIA, 1999; GLASSON; THERIVEL; CHADWI, 2005). Os objetivos-chave a serem considerados na fase do escopo, propostos por Fischer e Phylip-Jones (2008), são:

a) Informar o público sobre a proposta;

b) Identificar as principais partes interessadas, suas preocupações e valores;

c) Definir as alternativas a serem consideradas de forma razoável e prática;

d) Focar nas questões importantes e nos impactos significativos a serem abordados na avaliação ambiental;

e) Definir limites de tempo, espaço e assunto para a avaliação ambiental;

f) Estabelecer requisitos para coleta de dados de base e outras informações; e

g) Estabelecer o Termo de Referência (TR) para o EIA.

O envolvimento do público na fase do escopo traz benefícios para o processo, pois pode auxiliar a identificar questões significativas, como, por exemplo, informações sobre a área onde o empreendimento será implantado e outras alternativas a serem consideradas no projeto; assim, o TR poderá servir como um meio de verificação e resposta das contribuições populares realizadas (FISCHER, 2013). Na prática, a participação na fase do escopo ocorre na forma de consulta, onde é realizada a identificação de grupos interessados, mapeamento das preocupações do público, inclusão ou exclusão de questões do escopo do EIA/RIMA, aprimoramento do TR e consideração de alternativas para o projeto (SÁNCHEZ, 2013).

Se o escopo não for elaborado de forma adequada pode levar a uma situação em que trabalhos desnecessários são realizados, em que consequências significativas deixam de ser previstas durante o processo (SNELL; COWELL, 2006) ou em que recursos excessivos são dispendidos em impactos menores, levando a um EIA volumoso que contempla muitos impactos em profundidade (WOOD; GLASSON; BECKER, 2006).

\subsubsection{Elaboração dos estudos}

Após a determinação do escopo, o EIA (e o seu respectivo RIMA) é elaborado por uma empresa de consultoria ambiental contratada pelo proponente do projeto. O EIA e o RIMA servem para documentar de forma clara e imparcial: os impactos da proposta, as medidas propostas para mitigação, a significância dos efeitos ambientais, e as preocupações do 
público e das comunidades afetadas pela proposta (IAIA, 1999). No EIA, são abordados todos os aspectos técnicos necessários à avaliação dos impactos a serem gerados pelo empreendimento de forma multidisciplinar, já o RIMA deve apresentar os impactos gerados pelo empreendimento, propostas de mitigação e outras informações de forma clara e objetiva, utilizando uma linguagem acessível, ilustrações, quadros e outras técnicas de comunicação visual adequada para compreensão da população em geral (MMA, 2020).

O EIA é o documento mais importante do processo de AIA e é com base nele que são realizadas as negociações entre o empreendedor, governo e as partes interessadas e que serão tomadas as principais decisões sobre a viabilidade ambiental de um projeto (SÁNCHEZ, 2013). Por este motivo, o EIA deve ser compreensível e seu conteúdo deve, pelo menos, cumprir os requisitos da legislação de AIA (GLASSON; THERIVEL; CHADWI, 2005).

\subsubsection{Análise técnica}

Quando o EIA e o RIMA são finalizados, eles passam por uma análise técnica realizada pelo órgão ambiental responsável. Essa revisão tem como objetivo determinar se o EIA cumpre o seu termo de referência, se fornece uma avaliação satisfatória da proposta e se contém as informações necessárias para a tomada de decisões (IAIA, 1999).

Um estudo ambiental de qualidade apresenta um equilíbrio adequado entre descrição e análise, rigor metodológico e isenção, onde o texto não aponte apenas as vantagens do empreendimento, minimizando seus inconvenientes (SÁNCHEZ, 2013).

A abrangência e a precisão de um EIA são questões preocupantes no processo de AIA, pois muitos estudos não cumprem sequer os requisitos regulatórios mínimos e também não fornecem informações completas nas quais podem se embasar (GLASSON; THERIVEL; CHADWI, 2005).

\subsubsection{Participação pública}

A participação pública pode ser definida como o envolvimento de indivíduos ou grupos que estejam interessados ou que serão afetados de forma positiva ou negativa por um projeto proposto que está sujeito a um processo de tomada de decisão (ANDRÉ et al., 2006). Ela é um componente importante do processo de AIA e pode contribuir para a maior transparência do processo decisório, para mais completa identificação dos impactos potencialmente significativos e para a escolha de medidas adequadas para evitar, minimizar ou compensar os impactos adversos (DUARTE et al., 2016). Ainda, a participação pública é intrínseca à 
governança democrática (DIETZ; STERN, 2008) e tem sido cada vez mais institucionalizada em termos de governança ambiental em todo o mundo (WU; XU; ZHANG, 2018).

Ela deveria permear todo o processo de AIA, mas no caso brasileiro, a participação ocorre normalmente na forma de Consulta Pública na fase em que o EIA/RIMA está sob análise do órgão ambiental. Podem ser empregadas diferentes ferramentas para se estruturar a consulta pública no processo de AIA, como por exemplo, a realização de reuniões de pequenos grupos, oficinas de trabalho ou a realização de audiências públicas, sendo esta última a mais conhecida (SÁNCHEZ, 2013).

A audiência pública é convocada e conduzida pelo órgão ambiental competente, onde proponente e consultor são obrigados a fazer apresentações e responder a questões levantadas pelo público (DUARTE et al., 2017a). Nas últimas décadas, vários países instituíram mecanismos para expandir a participação em audiências públicas para apoiar ou, até mesmo, como uma alternativa aos mecanismos tradicionais de representação política e tomada de decisão (ALONSO; COSTA, 2004)

O tema da participação, por ser foco deste trabalho, será abordado em profundidade nos próximos capítulos deste referencial teórico.

\subsubsection{Tomada de decisão}

Após a realização da consulta pública e da análise técnica, o órgão responsável toma a decisão com relação ao projeto de um determinado empreendimento. Essa tomada de decisão consiste em aprovar ou rejeitar a proposta e estabelecer os termos e condições para a sua execução (IAIA, 1999). A depender da legislação vigente, também pode acontecer o envolvimento do conselho ambiental (municipal, estadual ou federal).

No caso de a decisão favorecer a emissão da licença, as etapas de pós-aprovação consistem no monitoramento e acompanhamento do empreendimento, no qual são elaborados relatórios periódicos sobre o desempenho ambiental das atividades e são realizadas visitas periódicas do órgão ambiental para fiscalização (SÁNCHEZ, 2013).

\subsubsection{Acompanhamento/monitoramento}

Após a tomada de decisão e essa sendo favorável ao projeto, o processo de AIA chega

na fase de acompanhamento/monitoramento, que tem como objetivo assegurar o cumprimento dos termos e condições de aprovação, monitorar os impactos e medidas de mitigação e realizar auditorias ambientais e avaliações de processos para otimizar a gestão ambiental (IAIA, 1999). 
Os controles de gestão promovidos por meio da etapa de acompanhamento reforçam a estrutura e o processo de AIA, e ao visar a melhoria contínua acabam melhorando a prática e o próprio sistema de AIA (MARSHALL; ARTS; MORRISON-SAUNDERS, 2005).

\subsection{Origem da participação pública nas questões ambientais}

Antes de abordar o tema da participação pública com enfoque na AIA, será apresentado neste capítulo como a participação surgiu nas questões ambientais.

Os processos participativos tiveram origem na democracia, a qual pode ser entendida como uma ordem construída onde as leis, as normas e as instituições são criadas pelas mesmas pessoas que as vão cumprir e proteger, ou seja, a força das instituições públicas e das leis que regem as relações da sociedade depende de que ambas reflitam o interesse dos cidadãos (TORO; WERNECK, 1996).

Poucas abordagens teóricas foram empreendidas para a definição da participação pública nas arenas decisórias (PALERM, 1999), sendo que uma delas foi levantada por Habermas, em 1987, que propunha um ideal normativo de um debate sem distorções, uma "situação de discurso ideal" como uma condição para estabelecer uma ação comunicativa (HABERMAS, 1987). Uma outra abordagem estabelecida por Foucault, em 1988, traz características do pósmodernismo e afirma que as relações de poder sempre vão existir e não podem ser eliminadas, rejeitando as tentativas de estabelecer um estado de comunicação ideal ou qualquer ideal normativo (FOUCAULT, 1988).

No que diz respeito ao ideal normativo para uma comunicação sem constrangimentos, é preciso reconhecer que a introdução de maiores graus de participação pública nos processos decisórios gera um maior grau de transparência nas decisões tomadas, mitigando as relações de poder (PALERM, 1999). Seguindo esta premissa, Arnstein (1969) desenvolveu uma classificação da participação de oito níveis. Estes níveis são organizados na disposição de uma escada (Figura 5), onde cada degrau corresponde ao nível de poder do cidadão na tomada de decisão: Manipulação, Terapia, Informação, Consulta, Pacificação, Parceria, Poder delegado e Controle Cidadão. 
Figura 5 - A escada da participação cidadã.

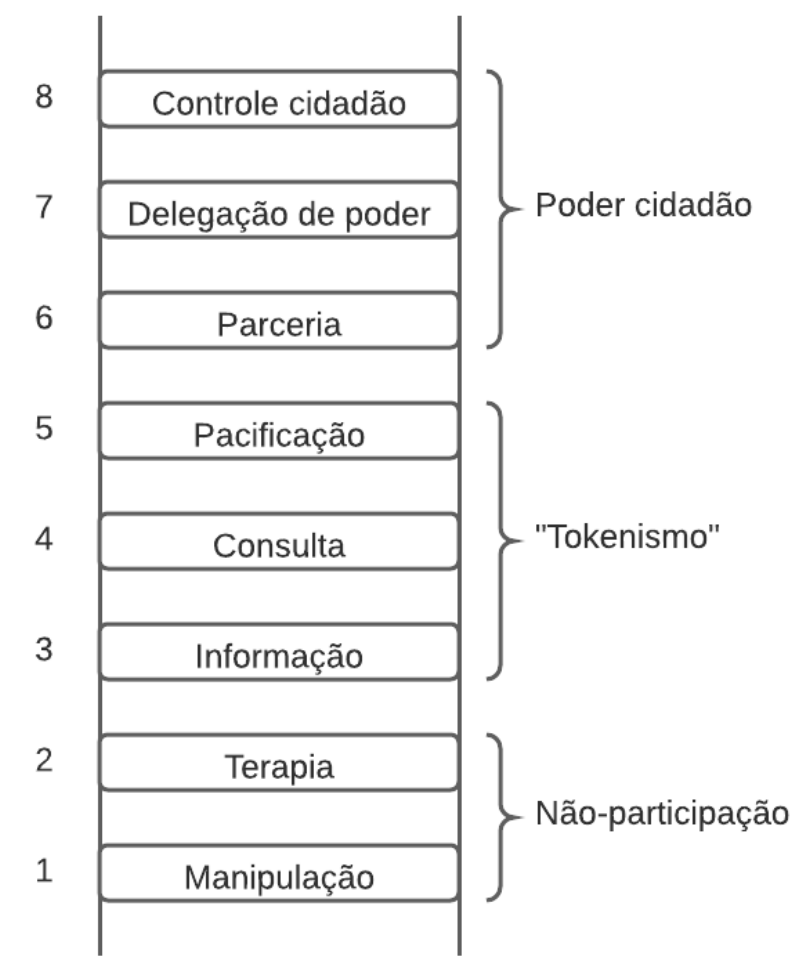

Fonte: ARNSTEIN (1969, tradução nossa).

Os dois primeiros degraus representam a situação de "não-participação", que tem como objetivo real não de permitir a população a participar, mas de criar uma situação em que os tomadores de decisão possam "educar" ou "curar" os participantes, quando a escada atinge o nível de "tokenismo", representa a concessão limitada de poder ao cidadão com o objetivo de evitar conflitos (ARNSTEIN, 1969). O degrau da informação é essencial para qualquer participação acontecer, e representa a situação em que as pessoas são informadas sobre um determinado assunto, já o momento da consulta acontece quando se quer conhecer o posicionamento de um indivíduo ou grupo de pessoas com relação a um determinado tema, e a pacificação pode ser entendida como a satisfação de algumas demandas levantadas pelo público, que supostamente já foi previamente informado e consultado (ARNSTEIN, 1969). Os três últimos degraus da participação são considerados formas mais efetivas, nos quais a parceria ocorre quando as demandas levantadas por um determinado grupo são satisfeitas por uma determinada organização em conjunto com a população por meio de negociações; a delegação de poder acontece quando existe uma mobilização social organizada e essa assume responsabilidades significativas atribuídas por uma determinada organização; o nível mais alto da escada é o controle cidadão, que também exige mobilização social organizada para que a atuação da população aconteça de maneira direta e integrada na gestão de diversos setores que contemplem os interesses coletivos (ARNSTEIN, 1969). 
Outra tentativa de classificar a participação em níveis foi feita pela International Association for Public Participation (IAP2), que desenvolveu um espectro da participação pública que define o papel do público em qualquer processo participativo (Figura 6).

Figura 6 - Espectro da participação pública

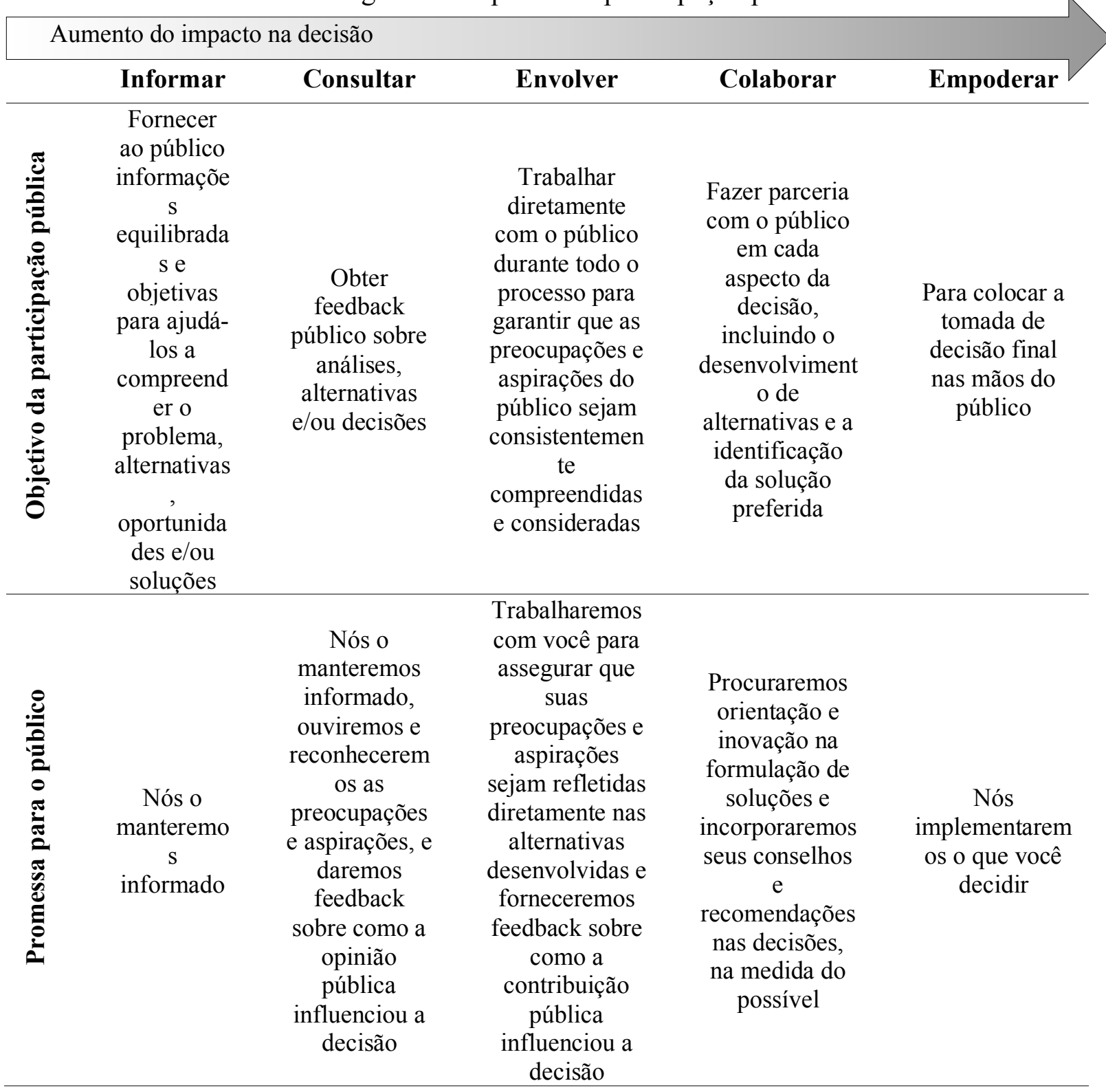

Fonte: IAP2 (2020, tradução nossa).

Estes modelos dimensionais realçam um ponto importante: o envolvimento dos cidadãos pode ser mais ou menos intenso, ou seja, mais ou menos influente; no entanto, essas variáveis não são as únicas dimensões sensíveis, pois não existe uma única medida de efetividade e nem todos os arranjos participativos podem ser ordenados em uma única classificação (BOBBIO, 2019).

Em meados do século XX, o direito a um ambiente sadio e ecologicamente equilibrado como um direito humano passou a receber reconhecimento explícito em leis nacionais e em 
tratados internacionais como, por exemplo, na declaração de Estocolmo, em 1972, elaborada nas Conferências promovidas pela Organização das Nações Unidas (ONU) (SÁNCHEZ, 2013). Assim, a conexão entre as questões ambientais e a participação pública foi feita pela primeira vez em nível global no princípio 10 da Declaração do Rio sobre Meio Ambiente e Desenvolvimento, em 1992 (MAUERHOFER, 2016), que apresentava:

As questões ambientais são melhor tratadas com a participação de todos os cidadãos interessados, ao nível pertinente. Em nível nacional, cada indivíduo deve ter acesso adequado às informações relativas ao ambiente que é detido pelas autoridades públicas, incluindo informação sobre materiais e atividades perigosas nas suas comunidades, e a oportunidade de participar nos processos de tomada de decisão. Os Estados devem facilitar e incentivar a sensibilização e a participação do público através de uma ampla informação disponível. Acesso efetivo a processos judiciais e administrativos, incluindo reparação e recurso, devem ser providenciados (UNEP, 1992, tradução nossa).

No Brasil, foi instituída também a Política Nacional de Participação Social (PNPS) e o Sistema Nacional de Participação Social por meio do Decreto Federal no 8.243, de 23 de maio de 2014. Esta política tinha como objetivo "fortalecer e articular os mecanismos e instâncias democráticas de diálogo e atuação conjunta entre administração pública federal e sociedade civil” (BRASIL, 2014), mas foi revogada cinco anos depois pelo Decreto Federal $n^{0}$ 9.759, de 11 de abril de 2019 (BRASIL, 2019).

O papel e a importância da participação do público na tomada de decisões ambientais foram enfatizados pela Convenção de Aarhus sobre Acesso à Informação, Participação e Acesso à Justiça em Questões Ambientais, realizada em 1998 (HARTLEY; WOOD, 2005). Esta convenção pode ser entendida como um acordo ambiental, pois associa direitos ambientais e direitos humanos, incorporando democracia, transparência e responsabilidade governamental, tendo o meio ambiente como ponto de partida (SÁNCHEZ, 2013).

O documento oficial da Convenção de Aarhus, publicado pela United Nations Economic Commission for Europe - UNECE (2018), tem como objetivo principal:

Contribuir para a proteção do direito de todas as pessoas presentes e futuras gerações a viver num ambiente adequado à sua saúde e bem-estar. Cada parte garantirá os direitos de acesso à informação, a participação do público nos processos decisórios e o acesso à justiça em matéria de meio ambiente, em conformidade com as disposições da presente Convenção (UNECE, 2018).

Os três pilares estabelecidos na Convenção de Aarhus são:

a) acesso à informação;

b) participação na tomada de decisões;

c) acesso à justiça. 
Uma das principais realizações da Convenção de Aarhus no que diz respeito à participação do público é a tomada de decisões em nível de projetos, ou seja, a participação do público no âmbito do processo de AIA (PALERM, 1999); e, ao relacionar o processo com os três pilares da Convenção, pode-se inferir que: a utilidade do acesso à informação depende de a informação ser compreendida pelo público leigo; a participação depende em parte de poder participar no diálogo (LEE; ABBOT, 2003); o acesso à justiça diz respeito ao direito de recorrer a procedimentos administrativos ou judiciais para contestar atos e omissões de instituições privadas ou autoridades públicas que violem as disposições do direito ambiental (EC, 2003).

Apoiada nos três pilares da Convenção de Aarhus, a International Association for Impact Assessment (IAIA) estabeleceu princípios de boas práticas internacionais, que têm como objetivos melhorar a prática da participação pública na $\mathrm{AI}$, estimular discussões entre as partes interessadas que resultem em melhores projetos, melhor desenvolvimento, governança colaborativa e um mundo mais sustentável (ANDRÉ et al., 2006). A participação na AIA será o assunto do próximo tópico.

\subsection{Participação pública na Avaliação de Impacto Ambiental}

O conceito da participação pública na democracia deliberativa e na justiça ambiental começaram a se relacionar com a AIA a partir dos anos 1990 (MORGAN, 2012), e a Convenção Aarhus representa um marco alcançado ao reconhecer a participação do público como um direito por si só (PETTS, 2003).

A participação pública é uma característica essencial no processo de AIA e deve conter mecanismos adequados para promover níveis satisfatórios de envolvimento na tomada de decisão (PETTS, 1999) e conseguir uma distribuição mais equitativa do poder político (O’FAIRCHEALLAIGH, 2010). A palavra participação tem sido utilizada na literatura acompanhada de diferentes adjetivos compondo termos como participação cidadã, participação popular e participação pública que carregam consigo diferentes conceitos abordados principalmente no campo da ciência política, no entanto, apesar das divergências a essência da participação do indivíduo permanece inalterada (FARIA; SILVA, 2017).

Atualmente, a execução da participação pública na AI deve ser baseada nos princípios de boas práticas estabelecidos pela IAIA (Tabela 1). 
Tabela 1 - Princípios básicos de boas práticas da participação pública na AI

\begin{tabular}{|c|c|}
\hline $\begin{array}{l}\text { Princípios } \\
\text { básicos }\end{array}$ & Definição \\
\hline $\begin{array}{l}\text { Adaptada ao } \\
\text { contexto }\end{array}$ & $\begin{array}{l}\text { Compreender e apreciar as instituições sociais, os valores e a cultura das } \\
\text { comunidades na área do projeto; } \\
\text { Respeitar os antecedentes históricos, culturais, ambientais, políticos e sociais } \\
\text { das comunidades que são afetadas por uma proposta. }\end{array}$ \\
\hline $\begin{array}{l}\text { Informativa e } \\
\text { proativa }\end{array}$ & $\begin{array}{c}\text { Reconhecer que o público tem o direito de ser informado antecipadamente e } \\
\text { de forma significativa nas propostas que possam afetar as suas vidas ou } \\
\text { meios de subsistência. } \\
\text { O aumento do interesse e motivação para participar ocorre através da } \\
\text { difusão de informação simples e compreensível para o público afetado e } \\
\text { interessado. }\end{array}$ \\
\hline $\begin{array}{l}\text { Adaptativa e } \\
\text { comunicativa }\end{array}$ & $\begin{array}{l}\text { Reconhecer que o público é heterogêneo de acordo com a sua demografia, } \\
\text { conhecimentos, poder, valores e interesses. Devem ser seguidas regras de } \\
\text { comunicação efetivas entre as pessoas, respeitando todos os indivíduos. }\end{array}$ \\
\hline $\begin{array}{l}\text { Inclusiva e } \\
\text { equitativa }\end{array}$ & $\begin{array}{l}\text { Assegurar que todos os interesses (incluindo os não representados ou } \\
\text { subrepresentados) serão respeitados no que se refere à distribuição de } \\
\text { impactos, compensações e beneficios. } \\
\text { A participação ou defesa dos interesses dos grupos menos representados } \\
\text { (povos indígenas, mulheres, crianças, idosos e pessoas pobres) deve ser } \\
\text { encorajada. } \\
\text { Deve ser promovida a equidade entre as gerações presentes e futuras, numa } \\
\text { perspectiva de sustentabilidade. }\end{array}$ \\
\hline Educativa & $\begin{array}{l}\text { Contribuir para o respeito e compreensão mútuos de todos os intervenientes } \\
\text { da AI no que se refere aos seus valores, interesses, direitos e obrigações. }\end{array}$ \\
\hline Cooperativa & $\begin{array}{l}\text { Promover a cooperação, a convergência e a criação de consenso em vez do } \\
\text { confronto. } \\
\text { Deve-se buscar engajar perspectivas e valores conflitantes, bem como tentar } \\
\text { alcançar uma aceitação geral da proposta em direção a uma decisão que } \\
\text { promova e apoie o desenvolvimento sustentável. }\end{array}$ \\
\hline Imputável & $\begin{array}{c}\text { Aprimorar a proposta em estudo, levando em consideração os resultados do } \\
\text { processo de participação pública; incluindo relatórios e feedback às partes } \\
\text { interessadas sobre os resultados do processo de participação pública, } \\
\text { considerando especialmente como suas contribuições colaboraram com a } \\
\text { tomada de decisões. }\end{array}$ \\
\hline
\end{tabular}

Fonte: Adaptado de André et al. (2006)

Embora seja incluída como obrigatória na maioria das legislações de AIA, a participação pública é deficiente nos países da América do Sul por conta da falta de procedimentos adequados (PETTS, 1999). Os regulamentos normalmente estabelecem requisitos mínimos para a participação do público, mas não especificam as disposições ou instrumentos institucionais específicos para aplicá-la (WIKLUND, 2005).

$\mathrm{Na}$ prática da AIA, as formas de participação podem variar e cada uma delas pode ser relevante para diferentes fases de um processo, desde a análise inicial, comunicação da proposta até a tomada de decisão, monitoramento e acompanhamento (ANDRÉ et al., 2006), como apresentado na Tabela 2. Ainda nesta tabela, para cada forma de participação é apresentado o(s) objetivo(s) e o(s) instrumento(s) a ser usado. 
Tabela 2 - Formas de participação na Avaliação de Impacto Ambiental

\begin{tabular}{ccc}
\hline $\begin{array}{c}\text { Formas de } \\
\text { participação na AIA }\end{array}$ & Objetivos & Instrumentos \\
\hline $\begin{array}{c}\text { Participação passiva ou } \\
\text { recepção de informação }\end{array}$ & Informar o público & $\begin{array}{c}\text { Meios de comunicação } \\
\text { (Forma unidirecional de } \\
\text { participação) }\end{array}$ \\
\hline $\begin{array}{c}\text { Participação por meio } \\
\text { de consulta }\end{array}$ & $\begin{array}{c}\text { Ouvir as opiniões e demandas do } \\
\text { público, considerando-as na } \\
\text { tomada de decisão }\end{array}$ & $\begin{array}{c}\text { Audiência pública e } \\
\text { reuniões públicas }\end{array}$ \\
\hline Participação interativa & Permitir o engajamento do público & $\begin{array}{c}\text { Grupos de trabalho, } \\
\text { negociação, mediação e } \\
\text { gestão conjunta }\end{array}$ \\
\hline
\end{tabular}

Fonte: Adaptado de André et al. (2006, tradução nossa)

Dentre os diversos objetivos da participação na AIA, Glucker et al. (2013) citam: influenciar decisões, aumentar a capacidade democrática, servir como aprendizado social, capacitar e emancipar grupos ou indivíduos marginalizados, aproveitar conhecimentos e informações locais, incorporar conhecimento experimental e baseado em valor, testar a robustez das informações de outras fontes, gerar legitimidade e resolver conflitos.

De acordo com Sánchez (2013), existem diferentes objetivos instrumentais da participação pública em diferentes momentos/etapas do processo de AIA. Estes objetivos estão mostrados na Tabela 3.

Tabela 3 - Objetivos da participação nas etapas da Avaliação de Impacto Ambiental

Etapa do processo

Apresentação da proposta

Triagem

Determinação do escopo do EIA

Preparação do EIA

Análise técnica

Decisão

Acompanhamento

\section{Objetivo de consulta}

Divulgar intenções do proponente e objetivos do projeto

Permitir eventuais questionamentos sobre a classificação do projeto em termos de impacto potencial e dos estudos ambientais necessários Identificar grupos interessados, identificar e mapear preocupações do público, incluir ou excluir questões do escopo do EIA, aprimorar os TRs, considerar alternativas ao projeto.

Identificar e caracterizar impactos, disseminar informações sobre métodos de estudo e seus resultados, incluir no diagnóstico ambiental o conhecimento que a população local tem do meio ambiente e aproveitálo na análise dos impactos, identificar medidas mitigadoras e compensatórias

Conhecer os pontos de vista do público para eventual consideração e incorporação ao parecer de análise

Levar em conta as opiniões dos interessados, considerar a distribuição social dos ônus e dos benefícios do projeto como um dos elementos da decisão

Contribuir para verificar o cumprimento satisfatório de compromissos e condicionantes, possibilitar que reclamações possam ser formuladas e atendidas. 
Conceber e implementar a participação pública é uma questão de extrema complexidade, tanto na teoria como na prática e, levando em conta essa problemática, muitos autores afirmam que para compreender a participação do público é fundamental entender a influência da população que se envolve nas decisões que afetam suas vidas (BROMBAL; MORIGGI; MARCOMINI, 2017).

\subsubsection{Desafios da participação pública na AIA}

A participação pública pode ser mais do que um requisito para o pleno andamento da implementação de um projeto (SHEPHERD; BOWLER, 1997). Entretanto, a prática da AIA ainda enfrenta o desafio geral de definir, conduzir e avaliar a participação pública de forma significativa para que as partes interessadas e afetadas participem efetivamente; a prática precisa identificar, reconhecer e fornecer medidas razoáveis de apoio àqueles que estão claramente em desvantagem e que têm dificuldades de participar (SIMPSON; BASTA, 2018).

Durante o envolvimento da comunidade, é comum que sejam enfrentados conflitos (SÁNCHEZ, 2013), evidenciando que tanto o conteúdo de um projeto quanto o processo são importantes e estão inter-relacionados com a formação de atitudes dos grupos interessados (O'FAIRCHEALLAIGH, 2010).

O público não é uma entidade homogênea, logo diferentes grupos têm preocupações e prioridades diferentes (GLASSON; THERIVEL; CHADWI, 2005; GLUCKER et al., 2013). Estas diferenças tendem a gerar maior dificuldade aos tomadores de decisão em atender às diversas expectativas, o que pode levar a frustrações, diminuição da vontade de participar nos momentos formais do processo e potencialmente levá-los a optar por outras maneiras de participação informais, como protestos e boicotes, por exemplo (GLUCKER et al., 2013).

Os empreendedores também não costumam ser favoráveis à participação do público, pois ela carrega consigo o risco de dar ao projeto um nível requintado ao incorporar exigências e aperfeiçoamentos, o que pode significar no aumento de gastos de tempo e dinheiro (GLASSON; THERIVEL; CHADWI, 2005)

Um outro problema levantado diz respeito ao envolvimento tardio do público, que normalmente acontece por meio de audiências públicas, as quais têm uma dinâmica desconfortável, onde a informação colocada à disposição das pessoas tem caráter técnico e científico (SÁNCHEZ, 2013). Isso dificulta o entendimento e impede que a população contribua com informações referentes aos seus valores sociais e culturais, que 
consequentemente são deixados de lado na identificação dos impactos dos projetos (ORTOLANO; SHEPHERD, 1995).

A avaliação das práticas de participação pública depende diretamente dos métodos utilizados e a forma como foram implementados (HARTLEY; WOOD, 2005), e algumas das principais barreiras que impedem a participação estão listadas a seguir:

a) Conhecimento insuficiente do público sobre questões de planejamento, questões legais e de licenciamento de resíduos;

b) Fornecimento insuficiente de informações;

c) Acesso deficiente a aconselhamento jurídico;

d) Desconfiança na indústria de eliminação de resíduos;

e) Síndrome "Not in my back yard" (NIMBY);

f) Falha em influenciar o processo de tomada de decisão;

g) Má execução dos métodos de participação; e

h) Restrições regulatórias (HARTLEY; WOOD, 2005).

\subsubsection{Benefícios da participação pública na AIA}

Apesar de todas as dificuldades enfrentadas na prática, a participação pública é vista como um mecanismo para evitar, ou pelo menos reduzir a ocorrência de conflitos (CASHMORE; RICHARDSON, 2013) e de atrasos de projetos, para promover a aprendizagem social (PETTS, 2003).

$\mathrm{O}$ reconhecimento das partes interessadas e afetadas por um empreendimento valoriza o processo de AIA de diversas maneiras e essas visões devem ser ativamente encorajadas e protegidas (MORGAN, 2012), especialmente em empreendimentos de alto impacto, assegurando que as opiniões dos diferentes grupos sejam devidamente levadas em consideração no processo de tomada de decisão (GLASSON; THERIVEL; CHADWI, 2005; SÁNCHEZ, 2013). Desta forma, o proponente também se beneficiará em termos da certeza do processo, sabendo que quando o processo de AIA tiver terminado, o projeto apresentará melhorias e terá maior aceitação pelas comunidades afetadas.

A participação do público na AIA pode ser utilizada positivamente para transmitir informações claras sobre um empreendimento, esclarecer mal-entendidos, permitir uma melhor compreensão das questões relevantes para populações locais e assim incorporar estas propostas no projeto, evitando oposições que atrasem o processo e problemas ambientais no futuro (GLASSON; THERIVEL; CHADWI, 2005). 


\subsection{Caracterização da participação pública no processo de AIA paulista}

Os procedimentos e a prática da participação pública no processo de AIA variam entre países e, algumas vezes, as diferenças existem também entre estados de um mesmo país, divergindo entre práticas de participação muito abrangentes até as mais superficiais (GLASSON; THERIVEL; CHADWI, 2005).

Os estados brasileiros têm os seus próprios quadros institucionais de AIA e Licenciamento e são capazes de definir legislação, regras e procedimentos específicos, a fim de complementar a regulamentação federal (MONTAÑO; DE SOUZA, 2015).

No estado de São Paulo, a execução da política ambiental é realizada no âmbito do Sistema Estadual de Administração da Qualidade Ambiental, Proteção, Controle e Desenvolvimento do Meio Ambiente e Uso Adequado dos Recursos Naturais de São Paulo (SEAQUA), instituído pela Lei Estadual $n^{\circ}$ 9.509/1997, que tem o objetivo de organizar, coordenar e integrar as ações de órgãos e entidades visando a proteção, o controle e o desenvolvimento do meio ambiente (SÃO PAULO, 1997). O órgão central é a Secretaria do Meio Ambiente (SMA), atualmente denominada como Secretaria de Infraestrutura e Meio Ambiente (SIMA), que tem a finalidade de planejar, coordenar, propor normas e supervisionar a Política Estadual do Meio Ambiente. Entre os órgãos executores e setoriais do SEAQUA vinculados a SMA, está a Companhia Ambiental do Estado de São Paulo (CETESB), responsável pelo licenciamento ambiental de âmbito estadual. Dentro da estrutura organizacional da CETESB, encontra-se a Diretoria de Avaliação de Impacto Ambiental (DAIA), responsável pelo Licenciamento de empreendimentos e atividades com AIA localizados no estado de São Paulo. Neste contexto, os procedimentos a serem seguidos pela CETESB, atualmente, são regulamentados pela Resolução CONAMA nº 1 de 1986 e Resolução CONAMA nº 237 de 1997 no âmbito federal e pela Decisão de Diretoria (DD) n ${ }^{\circ}$ 153 de 28 de maio de 2014 e Resolução SMA n ${ }^{\circ} 49$ de 28 de maio de 2014 no âmbito do estado de São Paulo.

De acordo com estes instrumentos legais, além da publicidade do processo e a possibilidade de qualquer interessado se manifestar sobre o empreendimento, é prevista a participação do público por meio da realização das audiências públicas, que acontecem após a elaboração do EIA/RIMA na etapa de consulta pública do processo de AIA. A Resolução CONAMA n ${ }^{\circ} 9$ de 1987 regulamenta a realização de audiências públicas no processo de licenciamento ambiental e estabelece que o órgão ambiental deverá realizar uma audiência pública para que a licença tenha validade e, no caso de o empreendimento ser complexo, poderá haver mais de uma sobre um mesmo projeto, garantindo também que a localização de 
todas as audiências aconteça em local de fácil acesso aos interessados (CONAMA, 1987). No âmbito estadual, a Deliberação CONSEMA No 01 de 14 de setembro de 2011 dispõe sobre as normas para solicitação, convocação e realização de audiências públicas e estabelece a obrigatoriedade das audiências para empreendimentos sujeitos a elaboração do EIA/RIMA; neste dispositivo são revogadas as deliberações CONSEMA anteriores, n 50/1992, 34/2001, 27/2002 e 07/2007, que tratavam sobre o tema das audiências públicas (CONSEMA, 2011).

As audiências realizadas durante a etapa de consulta pública dentro do processo de AIA são os eventos formais que tem como finalidade a realização de um debate público em que a população pode compartilhar opiniões e experiências que podem influenciar nos resultados de um processo, legitimando e aprimorando o processo de decisão (SÁNCHEZ, 2013).

Antes de a configuração dos dispositivos legais do estado de São Paulo se estabelecerem como é atualmente, existiam outros momentos que possibilitavam a participação durante o processo de AIA. Na antiga Resolução SMA n 49, de 28 de setembro de 2004 que dispunha sobre os procedimentos para Licenciamento Ambiental com AIA realizados pela CETESB, após o empreendedor protocolar o plano de trabalho para definição do TR era previsto a publicidade deste documento e o prazo de 15 dias para manifestação dos interessados, em seguida o Conselho Estadual de Meio Ambiente (CONSEMA) era ouvido antes de o órgão ambiental definir o TR. Após definir o TR, o empreendedor elaborava o EIA/RIMA e ao apresentar o estudo era dada a publicidade, então havia prazo de 30 dias para manifestação e de 45 dias para a solicitação de audiências públicas. Após a realização de audiências públicas o órgão ambiental emitia o parecer técnico e, então, o CONSEMA atuava novamente aprovando ou reprovando a viabilidade ambiental do empreendimento (SMA, 2004a). Esta resolução foi revogada pela Resolução SMA no 54 de 30 de novembro de 2004, a qual previa como formas de participação as mesmas da normativa anterior com alteração no prazo para manifestações sobre o plano de trabalho que mudaram de 15 para 45 dias e sobre o EIA/RIMA, que passaram de 30 para 45 dias (SMA, 2004b).

Com o objetivo de revogar as disposições previstas na Resolução SMA no 54 de 2004, em 2014, foi promulgada a Resolução SMA nº 49 de 28 de maio de 2014, a qual dispõe sobre os procedimentos para Licenciamento Ambiental com Avaliação de Impacto Ambiental, no âmbito da CETESB (SMA, 2014). Com relação à participação prevista neste dispositivo que vigora até os dias de hoje houve modificações. Após decidir sobre a realização de EIA/RIMA o empreendedor dever apresentar o TR para elaboração do estudo e, logo em seguida, o órgão ambiental define o TR sem ouvir o CONSEMA e após é dada a devida publicidade do documento. Após a apresentação do EIA/RIMA continuou prevista a publicidade do estudo 
seguida do prazo de 45 dias para manifestação e solicitação de audiências públicas. Após a realização das audiências o EIA/RIMA é analisado levando em consideração as complementações exigidas pela CETESB, as manifestações de órgãos ou entidades competentes envolvidas no processo e as contribuições apresentadas em audiência pública e aquelas enviadas pelos interessados (CETESB, 2014). Em seguida, o órgão ambiental emite o parecer técnico sobre a viabilidade ambiental do empreendimento e encaminha para o CONSEMA que, por sua vez, emite seu próprio parecer sobre a decisão tomada pelo órgão ambiental acerca da emissão da LP e suas condicionantes. O CONSEMA é um órgão consultivo, normativo e recursal que atua para aprimorar a gestão ambiental do estado, tendo em sua composição diversos segmentos organizados da sociedade, ambientalistas, universidades, setor produtivo e órgãos de classe (SÃO PAULO, 2021).

A existência de diversos canais e mecanismos que permitem a participação social, embora seja um requisito fundamental para uma governança democrática, não necessariamente induz uma maior qualidade na participação (IPEA, 2013). Para minimizar os problemas existentes na participação pública no processo de AIA, a sociedade pode recorrer ao Poder Judiciário, solicitando a garantia dos direitos ambientais ao Ministério Público (MP). De acordo com Machado (2013), recorrendo à Constituição Federal (BRASIL, 1988), o MP tem a função constitucional de acompanhar zelosamente a elaboração e a implementação dos diversos planos ambientais previstos na legislação e também a preparação, fase de comentários e de audiência pública dos estudos ambientais. A participação do MP em um processo de AIA ocorre por meio da expedição de recomendações aos órgãos competentes solicitando a elaboração ou reformulação de estudos ambientais, recomendando o tipo de local e horário de audiência pública, solicitando a realização de inspeções e apuração de infrações administrativas contra o meio ambiente e também solicitando que o órgão ambiental não emita a licença enquanto o inquérito civil não termine (MACHADO, 2013).

É possível observar que as mudanças nas resoluções ao longo do tempo reduziram os momentos participativos do processo de AIA do estado de São Paulo. Este tipo de mudança na legislação existente pode indicar uma maneira de flexibilizar e acelerar o processo de emissão de licenças ambientais, caminhando contra a ampliação da participação dos setores atingidos pelos impactos de obras licenciadas, retroagindo as conquistas sociais já consolidadas (BORGES, 2013). Os desafios para incorporar a participação nos dispositivos legais são muitos e a política ambiental no Brasil ainda está desprovida de mecanismos que propiciem a resolução de conflitos ambientais; isso ocorre por conta da desigualdade das 
condições que os representantes dos diversos interesses envolvidos têm para participar, comprometendo a representações da sociedade civil (AGRA FILHO, 2008). 


\section{METODOLOGIA}

Este capítulo descreve a metodologia de pesquisa utilizada. A primeira etapa, se destinou a apresentar os procedimentos realizados para definição do estudo de caso e, a segunda etapa, dedicou-se a descrever a abordagem metodológica utilizada para análise dos casos.

Para explorar e entender a participação pública no processo de AIA do estado de São Paulo, esta pesquisa utilizou uma abordagem de métodos mistos, que associa formas qualitativas e quantitativas na coleta ou análise dos dados em um estudo (CRESWELL, 2010). Esta pesquisa foi majoritariamente qualitativa, no entanto, especificamente para a análise dos dados da Pergunta 1 do questionamento preliminar - detalhada no item 4.1 deste capítulo - optou-se por quantificar os dados obtidos, de modo que, a partir dos resultados dessa análise quantitativa, a próxima etapa do estudo fosse justificada. Também aplicou-se uma análise de certa forma quantitativa, por envolver estatística, em alguns dados por meio do uso do programa IRAMUTEQ (Interface de R pour les Analyses Multidimensionnelles de Textes et de Questionnaires).

A estrutura da metodologia utilizada está representada na Figura 7 e será detalhada na sequência. Cabe destacar que alguns passos dependiam dos resultados do passo anterior, sendo os procedimentos ajustados em função disso.

Figura 7 - Estrutura da metodologia

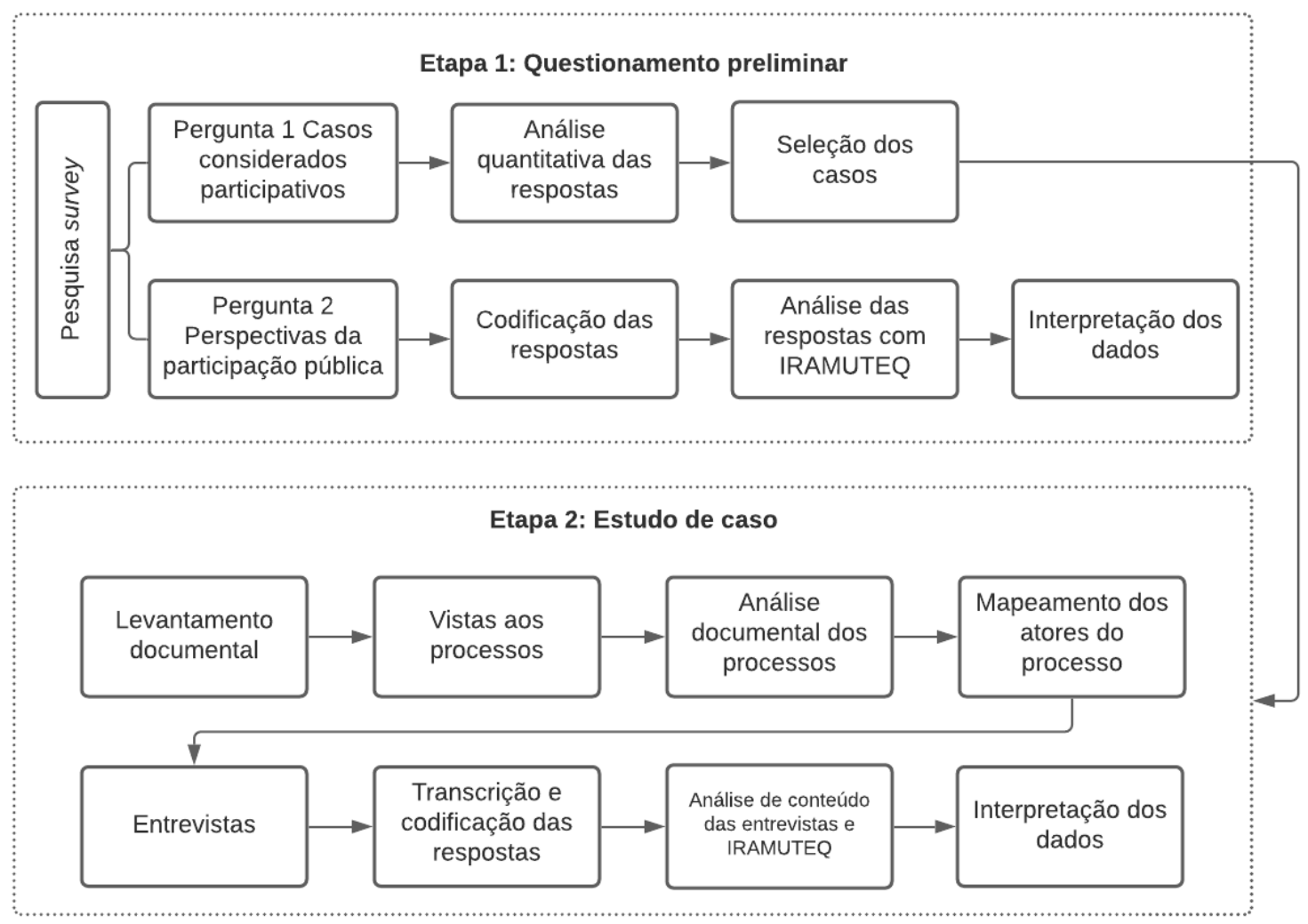

Fonte: Elaborado pela autora 


\subsection{Etapa 1: Questionamento preliminar}

Para realização do questionamento preliminar foi utilizado o método de pesquisa survey, definido por Chambliss e Scuhtt (2018) como uma pesquisa que tem por objetivo recolher informações de uma amostra de indivíduos por meio das suas respostas a um conjunto de perguntas padronizadas. Os indivíduos, nesta pesquisa, eram diferentes grupos de atores envolvidos com a AIA. A pesquisa survey foi de cunho explanatório com o intuito de testar uma teoria e suas relações causais (PINSONNEAULT; KRAEMER, 1993), no caso, a proposta era fazer um levantamento de casos considerados participativos na AIA do estado de São Paulo e "por quê" assim eram considerados.

A definição da amostra de participantes da pesquisa não foi probabilística, ou seja, foi obtida a partir de um critério em que nem todos os elementos da população têm a mesma chances de serem escolhidos, tornando os resultados não generalizáveis (FREITAS et al., 2000). O critério levado em consideração para a escolha dos participantes da pesquisa survey foi o de similaridade, julgando que as pessoas selecionadas representassem atores possivelmente envolvidos em um processo de AIA e que teriam experiência prática e teórica para responder ao questionamento.

Foram contatadas 341 pessoas utilizando a ferramenta do e-mail, no período de dezembro de 2018 a julho de 2019. Apesar deste formato de pesquisa survey utilizando o email apresentar limitações de baixa taxa de resposta e ser fraca no ponto de vista de amostragem (CHAMBLISS; SCHUTT, 2018), a modalidade foi escolhida por conta da limitação de tempo e de recursos financeiros.

Os endereços eletrônicos dos indivíduos contatados foram acessados de três formas: pela lista de participantes do Congresso Brasileiro de Avaliação de Impacto (CBAI), e-mails de professores que pesquisam e publicam na área de AIA e indicação de funcionários do órgão ambiental ligados ao Departamento de Avaliação de Impacto Ambiental (DAIA) e ao CONSEMA. Neste último caso, foi estabelecido contato via telefone com o órgão ambiental e solicitou-se o contato com algum representante técnico do DAIA; em seguida, o técnico em questão disponibilizou seu e-mail e de outros colegas que poderiam contribuir com a pesquisa.

$\mathrm{Na}$ lista de nomes para este primeiro contato foram contempladas empresas de consultoria ambiental, órgão ambiental, conselhos, organizações não governamentais (ONGs), instituições públicas e especialistas da área de AIA (professores e pesquisadores).

Antes de iniciar a pesquisa survey, foi realizada uma etapa piloto de pré-teste, enviando as perguntas por e-mail para 12 pessoas da lista, de modo a verificar se todas as questões 
foram respondidas corretamente e se as respostas não indicaram dificuldade quanto ao entendimento da questão (FREITAS et al., 2000). Segue abaixo o formato inicial das perguntas enviadas:

1) Você se lembra de algum(ns) caso(s) em que considera que a Participação Pública foi efetiva no processo de AIA do estado de São Paulo?

2) Por que você considera que a participação neste processo foi efetiva?

Após realizar o pré-teste, verificou-se que a palavra "efetiva" causou confusão para alguns dos participantes, pois, muitas vezes, não compreendiam o significado da palavra ou divergiam entre si sobre o que seria uma participação efetiva. Por este motivo, o texto do email foi modificado e a expressão "foi efetiva" foi removida e substituída pela expressão "teve destaque", como demonstrado na Tabela 4.

Tabela 4 - Perguntas do questionamento preliminar

\begin{tabular}{|c|c|}
\hline Pergunta 1 & Pergunta 2 \\
\hline $\begin{array}{c}\text { Você se lembra de algum(ns) caso(s) em que a } \\
\text { Participação Pública teve destaque no processo de AIA } \\
\text { do estado de São Paulo? }\end{array}$ & $\begin{array}{l}\text { Por que você considera que a } \\
\text { participação neste processo teve } \\
\text { destaque? }\end{array}$ \\
\hline
\end{tabular}

Fonte: Elaborado pela autora

Após a modificação, um modelo padrão de questionário preliminar foi enviado por email para todas as pessoas da lista, incluindo aquelas que não haviam compreendido o sentido da palavra "efetiva". Para os participantes em que foi possível ter acesso ao número de telefone, uma ligação foi feita apresentando a pesquisa e depois convidando a pessoa a responder as perguntas enviadas por e-mail.

As respostas recebidas foram registradas em uma planilha, organizando os participantes em grupos, de acordo com as instituições as quais pertenciam e as perguntas 1 e 2 foram registradas de forma separada uma da outra, de modo que facilitasse a identificação dos casos citados. Um exemplo da planilha está demonstrado na Tabela 5.

Tabela 5 - Registro das respostas do questionamento preliminar

\begin{tabular}{|c|c|c|c|c|c|c|c|c|c|c|c|}
\hline \multicolumn{3}{|c|}{ Pesquisadores } & \multicolumn{3}{|c|}{ Órgão ambiental } & \multicolumn{3}{|c|}{$\begin{array}{c}\text { ONGs, Conselhos } \\
\text { e instituições } \\
\text { públicas }\end{array}$} & \multicolumn{3}{|c|}{$\begin{array}{c}\text { Consultoria } \\
\text { ambiental }\end{array}$} \\
\hline 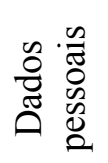 & $\begin{array}{l}\frac{\pi}{0} \\
0 \\
0 \\
0 \\
0 \\
0\end{array}$ & 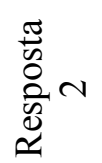 & 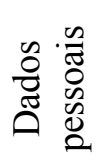 & 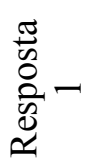 & 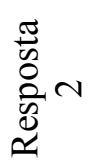 & 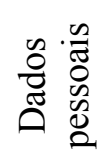 & 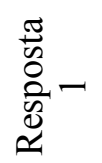 & 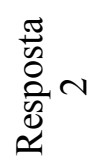 & 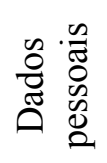 & 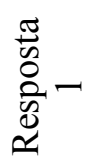 & 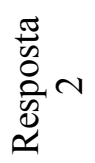 \\
\hline
\end{tabular}


Após tabular os dados, foi realizada uma análise individual para cada pergunta, de modo que fossem apresentadas separadamente na seção de resultados e discussão.

\subsubsection{Seleção dos casos}

Após organizar as respostas da Pergunta 1, elas foram analisadas de forma quantitativa de modo a determinar quais casos de empreendimentos que passaram pelo processo de AIA foram citados, quantas vezes e a que grupo pertenciam os participantes respondentes (Tabela $6)$.

Tabela 6 - Análise da Pergunta 1 do questionamento preliminar

\begin{tabular}{ccccccc}
\hline $\begin{array}{c}\text { Lista } \\
\text { de } \\
\text { casos }\end{array}$ & $\begin{array}{c}\text { Número } \\
\text { de } \\
\text { citações }\end{array}$ & Pesquisadores & $\begin{array}{c}\text { Órgão } \\
\text { ambiental }\end{array}$ & $\begin{array}{c}\text { ONGs, } \\
\text { Conselhos, } \\
\text { instituições } \\
\text { públicas }\end{array}$ & $\begin{array}{c}\text { Consultoria } \\
\text { ambiental }\end{array}$ & $\begin{array}{c}\text { Citado por } \\
\text { mais de 1 } \\
\text { participante }\end{array}$ \\
\hline $\begin{array}{c}\text { Caso } \\
\mathbf{1}\end{array}$ & $\mathrm{n}$ & $\mathrm{X}$ & $\mathrm{x}$ & $\mathrm{x}$ & $\mathrm{x}$ & Sim ou não \\
\hline $\begin{array}{c}\text { Caso } \\
\mathbf{2}\end{array}$ & $\mathrm{n}$ & $\mathrm{X}$ & $\mathrm{x}$ & $\mathrm{x}$ & $\mathrm{x}$ & Sim ou não \\
\hline $\begin{array}{c}\text { Caso } \\
\mathbf{n}\end{array}$ & $\mathrm{n}$ & $\mathrm{X}$ & $\mathrm{x}$ & $\mathrm{x}$ & $\mathrm{x}$ & Sim ou não \\
\hline
\end{tabular}

Fonte: Elaborado pela autora.

Esta análise foi utilizada para identificar os casos mais citados pelos participantes e foi determinante para definição das próximas etapas desta pesquisa. Após a tabulação dos dados, todos os casos foram organizados em uma planilha, seguindo a ordem de mais citado para menos citado. Para realizar uma triagem dos casos foram seguidos os seguintes passos:

a) Primeira seleção: De todos os casos, foram escolhidos apenas aqueles que foram citados por mais de um grupo (Pesquisadores, órgão ambiental, ONGs, conselhos, instituições públicas e consultoria ambiental).

b) Segunda seleção: Com a lista de casos pré-selecionados, foi realizada uma busca por dados referentes aos processos, ou seja, o nome oficial registrado no sistema do órgão ambiental e o número. Os casos em que não foi possível identificar o número do processo foram descartados, passando, então, para a última etapa de seleção.

c) Terceira seleção: Consistiu em verificar a extensão do processo em volumes e a disponibilidade de acesso ao processo físico para vistoria nas dependências do órgão ambiental. Os processos em que foram constatadas dificuldades para acesso foram retirados da lista. 
d) Quarta seleção: Dentre os processos que permaneceram na lista após as três etapas anteriores, foi selecionado o mais citado pelos participantes do questionamento preliminar para ser utilizado como estudo de caso nesta pesquisa.

A metodologia para conduzir o estudo de caso está descrito no item 4.2 desde capítulo.

\subsubsection{Percepções da participação pública}

As respostas da Pergunta 2 recebidas por e-mail foram organizadas em uma planilha do Excel e uma primeira leitura foi realizada para compreensão do texto.

$\mathrm{Na}$ fase de tratamento e análise dos resultados, utilizou-se o software francês IRAMUTEQ, um programa livre desenvolvido por Pierre Ratinaud, e que tem sua configuração baseada no software R e na linguagem python que permite realizar análises estatísticas em corpus textuais ou tabelas (IRAMUTEQ, 2020). Este software viabiliza diferentes tipos de análises de dados textuais, como a lexicografia básica (cálculo de frequência de palavras), análises multivariadas (classificação hierárquica descendente, análises de similitude) e organização do vocabulário (análise de similitude e nuvem de palavras) (CAMARGO; JUSTO, 2013).

Para que os dados pudessem ser processados no IRAMUTEQ, as respostas recebidas foram organizadas em só um documento no formato .txt, formando o corpus textual, ou seja, um conjunto de textos que se pretende analisar. Os textos das respostas de cada participante que compuseram este corpus foram separados por linhas de comando, seguindo um código de asteriscos $(* * * * *$ identificador do segmento de texto) e passaram por uma correção ortográfica. Também foram eliminados caracteres especiais presentes no texto, como aspas, cifrão, parênteses, marcas de oralidade e conjugações pronominais de verbos. Palavras compostas tiveram o espaço substituído por underline, como, por exemplo, "licenciamento ambiental", substituída por "licenciamento_ambiental" e os números foram escritos por extenso. Na sequência, foi realizada uma padronização de siglas e termos na qual expressões como "participação do público", "participação da população", "participação da sociedade", foram consideradas como "participação_pública". O termo audiência pública e audiências públicas, foram todos generalizados para o plural: "audiências_públicas”. Variações de expressões relacionadas à participação da sociedade como a "sociedade foi envolvida", "as comunidades se mobilizaram" foram generalizadas com o termo “mobilização_da_sociedade". As expressões como "o projeto foi alterado" "implicou em mudanças no projeto", "culminou na mudança de área", "mudou uma tecnologia para o desenvolvimento do projeto" foram todas consideradas como "alteração do projeto". As 
expressões como "demonstrou inviabilidade ambiental do projeto", "projeto não foi implementado" foram generalizados e considerados como “inviabilizou_o_projeto". Jargões da área como "avaliação de impacto ambiental" foram mantidos em seu formato de sigla: AIA. Todos estes ajustes seguiram as recomendações para melhor uso do programa.

A análise escolhida para o processamento dos dados textuais da pergunta 2 foi a nuvem de palavras, uma análise lexical que permite o agrupamento e organização gráfica de palavras em função da sua frequência, permitindo uma rápida identificação das palavras-chave de um corpus (CAMARGO; JUSTO, 2013). Outros tipos de análise foram testados, mas a nuvem de palavras foi a mais adequada. A partir da nuvem de palavras gerada, ela foi interpretada paralelamente com as respostas originais, de modo a verificar o contexto em que as palavras foram utilizadas pelos participantes ao colocarem suas percepções. Assim, os resultados trouxeram informações sobre o tema da participação e de como ela é entendida pelos atores envolvidos no processo.

\subsection{Etapa 2: Estudo de caso}

De acordo com Steiner (2011), a interface política-meio ambiente é uma área com inúmeras possibilidades de estudo e que pode beneficiar-se consideravelmente de estudos de caso e suas diversas possibilidades de análise e extração de inferências.

O estudo de caso é uma investigação empírica de um fenômeno contemporâneo em profundidade em seu contexto de mundo real (YIN, 2015), e tem como característica a análise das relações entre o contexto e o caso estudado contribuindo para a teoria existente sobre o tema abordado (MILLS; DUREPOS; WIEBE, 2009).

Os estudos de caso a serem usados nesta etapa foram decorrentes das respostas da pergunta 1 realizada na etapa anterior da pesquisa. A análise das respostas e a justificativa para a seleção do caso serão apresentadas em mais detalhes na seção de resultados. No entanto, como esta informação é base para o restante da pesquisa, cabe destacar que foi selecionado apenas um caso, disparadamente o de maior destaque nas respostas da primeira pergunta do questionamento preliminar, sendo o processo de Licenciamento com AIA do Rodoanel Metropolitano de São Paulo, o qual foi dividido em 4 trechos (Norte, Sul, Leste e Oeste).

A análise deste estudo de caso utilizou duas fontes de evidência: documentos e entrevistas. $\mathrm{O}$ uso de múltiplas fontes de evidência na pesquisa de estudo de caso permite que o pesquisador aborde uma variação maior de aspectos históricos e comportamentais, 
desenvolvendo linhas convergentes de investigação e tornando as conclusões mais convincentes e acuradas (YIN, 2015).

\subsubsection{Análise documental e mapeamento de atores}

Para realizar a análise documental, foi solicitado o acesso aos arquivos referentes aos processos de AIA do caso do Rodoanel Metropolitano de São Paulo dos 4 trechos (Norte, Sul, Leste e Oeste) até a emissão da licença prévia. Os processos analisados iniciaram com o Trecho Oeste do empreendimento em 1997, seguindo com o Trecho Sul em 2004, Trecho Leste em 2009 e o Trecho Norte em 2010.

O órgão ambiental autorizou o agendamento de vistas aos processos e separou os volumes que estavam disponíveis para consulta. Cabe destacar que o processo completo dos quatro trechos era denso, composto por cerca de 300 a 400 volumes cada um, e que o órgão ambiental não disponibilizou todos para análise, o que também seria impossível de ser executado no tempo de pesquisa. Por este motivo, foi estabelecido o recorte de análise do processo até a emissão da LP, totalizando 57 volumes, cerca de 9 mil páginas. Assim, foram priorizados para análise os volumes disponibilizados onde as informações sobre participação estavam mais presentes. Por exemplo, os documentos relativos ao EIA e ao RIMA não foram analisados. Apesar disso, as informações disponibilizadas foram adequadas e suficientes para atender aos objetivos propostos.

Então, foram agendadas, inicialmente, duas datas (28/08/2019 e 29/08/2019) no órgão ambiental para realizar vistas aos 4 processos, um referente a cada trecho do Rodoanel. No entanto, este intervalo de tempo não foi suficiente para fotografar todas as páginas dos documentos, sendo necessário solicitar mais dias para continuar o acesso. Por conta disso, as vistas aos processos foram feitas em 6 dias (28/08/2019, 29/08/2019, 30/08/2019, 03/09/2019, 04/09/2019 e 5/09/2019) e, na ocasião, os documentos foram fotografados para posterior análise.

A análise foi feita com a leitura dos documentos disponibilizados, orientada pelos objetivos de: entender a linha do tempo do processo de AIA do Rodoanel, fazer inferências sobre a participação pública, e identificar e mapear os atores envolvidos nos 4 processos (organizações, consultorias ambientais, órgãos públicos, conselhos, etc). De acordo com Bowen (2009), a evidência documental pode ser combinada com os dados de entrevistas para minimizar o viés e trazer maior credibilidade para o estudo. Deste modo, as informações extraídas dos documentos auxiliaram na elaboração das perguntas do roteiro de entrevistas e foram utilizadas para contextualizar os dados coletados durante as entrevistas. 
O mapeamento dos atores dos processos foi realizado durante a leitura dos documentos e registrado em uma planilha do Excel que contemplava as principais informações de cada ator identificado, como o nome, instituição a qual era vinculado e a qual trecho do Rodoanel pertencia o processo no qual foi identificado. Além dessas classificações, os atores foram divididos em quatro grupos, a fim de poder entrevistar atores com diferentes visões e interesses no processo:

a) Grupo A - Órgão ambiental e CONSEMA

b) Grupo B - Consultoria Ambiental e DERSA (empreendedor)

c) Grupo C - Poder público (Prefeituras, conselhos, secretarias, fundações, etc.)

d) Grupo D - Sociedade Civil

Um exemplo da planilha utilizada para organizar os dados está representada na Tabela 7.

Tabela 7 - Quadro para mapeamento dos atores

\begin{tabular}{|c|c|c|c|c|}
\hline \multirow{2}{*}{ Trecho } & Grupo A & Grupo B & Grupo C & Grupo D \\
\hline & \multicolumn{4}{|c|}{ Nome, instituição e contato } \\
\hline Norte, Sul, Leste, ou Oeste & \multicolumn{4}{|c|}{ Telefone, e-mail ou redes sociais } \\
\hline
\end{tabular}

Após finalizar o mapeamento, foi realizada uma busca pelo nome de cada ator identificado na plataforma Google, de modo a vasculhar informações que permitiriam o contato com cada um deles, como por exemplo, o número de telefone, e-mail ou contas em redes sociais (Twitter, Facebook e Linkedin). Quando algum meio de comunicação era identificado, a planilha era alimentada com o dado; quando não era possível encontrar nenhuma forma de aproximação com um ator, este era marcado com um código de impossibilidade de contato e não passava para o próximo filtro. Nesta primeira busca de todos os contatos mapeados, já foram eliminados diversos nomes da lista por não ser possível encontrar nenhuma forma de contato ao realizar a pesquisa na internet ou porque a pessoa já havia falecido devido aos processos do Rodoanel serem muito antigos. Dentre os atores que foi possível estabelecer uma forma de contato, foi enviada uma mensagem com uma abordagem inicial para apresentar a pesquisa e para convidá-la a participar concedendo uma entrevista. Após essa abordagem muitos dos atores contatados sequer responderam a mensagem e alguns dos que retornaram se recusaram a participar desta pesquisa. Uma vez que a pessoa aceitava o convite, era enviado o roteiro semiestruturado de perguntas e uma via do Termo de Consentimento Livre e Esclarecido (TCLE) emitido pelo Comitê de Ética 
em Pesquisa (CEP) que informava os detalhes desta pesquisa, os objetivos, benefícios e riscos da participação, o nível do envolvimento do participante e garantia a confidencialidade e o direito de se retirar da pesquisa a qualquer momento (ANEXO A). O projeto de pesquisa foi registrado no Comitê de Ética sob o número CAAE 21939219.4.0000.5504, tendo o parecer de número 3.943.832 como favorável.

\subsubsection{Entrevistas}

Para os atores que responderam concordando em participar desta pesquisa, foram agendadas entrevistas para serem realizadas via telefone, Skype, Google Meet ou Zoom, de acordo com a preferência do entrevistado.

As entrevistas realizadas no período de 23/04/2020 a 08/05/2020 seguiram um conjunto de perguntas conduzidas por um roteiro semiestruturado. A realização da entrevista semiestruturada tem como objetivo fazer com que o entrevistado auxilie no detalhamento das informações e interpretações dos estudos de caso (BONI; QUARESMA, 2005), fornecendo ao pesquisador percepções específicas sobre o tema, como também sugestões de fontes nas quais podem-se buscar evidências complementares.

Foram realizadas perguntas com a finalidade de obter informações sobre como a participação do público ocorreu no caso do Rodoanel, sobre a importância e os desafios da prática da participação pública na AIA e de obter sugestões de melhoria para a participação. O roteiro semiestruturado de perguntas está disponível no Apêndice A.

Para dar seguimento à análise dos dados, as entrevistas foram gravadas com o consentimento de cada ator e, posteriormente, foram transcritas manualmente pela pesquisadora, garantindo a fidelidade das respostas e o sigilo dos participantes. Para a análise de transcrição das entrevistas, foi utilizado o método de análise de conteúdo proposto por Bardin (1977), seguindo três fases: pré-análise, exploração do material e tratamento dos resultados e interpretação.

$\mathrm{Na}$ fase da pré-análise, as transcrições foram organizadas, revisadas gramaticalmente e sintetizadas de acordo com a ordem de perguntas do roteiro. As perguntas extras ao roteiro, ou seja, que surgiram durante a condução das entrevistas, também permaneceram registradas nos arquivos. Posteriormente, essas transcrições foram enviadas individualmente para cada entrevistado, de modo que pudessem ler e fazer correções caso achassem necessário, gerando a versão final de cada uma das transcrições e com as informações que seriam utilizadas. A partir dessa versão final, foi iniciada uma leitura flutuante para conhecer o texto e trechos 
importantes foram destacados, de modo a interpretar o conteúdo das respostas de cada uma das perguntas da entrevista.

$\mathrm{Na}$ fase de exploração do material, foram definidas as unidades de registro e de contexto. A unidade de registro adotada nesta pesquisa foi o tema das respostas dos entrevistados, ou seja, considerou o nível semântico das informações obtidas. O tema é uma afirmação, alusão ou proposições acerca de um assunto e é utilizado como unidade de registro para estudar motivações de opiniões, atitudes e tendências para descobrir núcleos de sentido (BARDIN, 1977). A unidade de contexto definida para esta análise foram as perguntas do roteiro de entrevistas. As unidades de contexto são a parte mais ampla do conteúdo a ser analisado e atuam como o pano de fundo que traz significado às unidades de registro (FRANCO, 2007). Após estabelecer as unidades, o texto transcrito das entrevistas foi codificado em uma planilha do Excel de acordo com o modelo da Tabela 8.

Tabela 8 - Codificação das entrevistas

\begin{tabular}{cc}
\hline Unidade de registro & Unidade de contexto \\
\hline Tema & Pergunta 1 \\
\hline Tema & Pergunta 2 \\
\hline Tema & Pergunta 3 \\
\hline Tema & Pergunta 4 \\
\hline Tema & Pergunta 5 \\
\hline Tema & Perguntas extras \\
\hline
\end{tabular}

Fonte: Elaborado pela autora.

$\mathrm{Na}$ fase de tratamento dos dados e interpretação foi utilizado o software IRAMUTEQ para analisar as respostas de cada uma das perguntas do roteiro de entrevistas de modo a dar suporte à interpretação dos resultados. O rito para codificação e processamento dos dados foi o mesmo seguido para análise da pergunta 2 do questionamento preliminar, demostrado no item 4.1.2 desta metodologia. A partir dos resultados foi possível gerar nuvens de palavras que sintetizaram as informações obtidas pelas entrevistas. A análise no IRAMUTEQ foi aplicada a todas as perguntas realizadas na entrevista. No entanto, devido à complexidade das respostas, apenas em alguns casos os resultados do software trouxeram informações cuja interpretação foi relevante, sendo apresentados apenas estes casos.

\subsubsection{Interpretação dos dados}

Após a realização de todas as fases do procedimento metodológico, todas as evidências sobre o caso do Rodoanel extraídas da análise documental e das entrevistas foram 
interpretadas e utilizadas para descrever e analisar a participação no processo de licenciamento com AIA dos quatro trechos do empreendimento até a emissão da licença prévia. Para classificar as formas de participação envolvidas em cada etapa da AIA analisada foi usado André et al. (2006) e Faria (2017).

As evidências da percepção sobre a participação pública no processo de AIA reunidas na primeira etapa da metodologia (pergunta 2 da pesquisa survey), foram utilizadas para corroborar com a análise dos dados das entrevistas. A partir desta conexão, os resultados foram interpretados e descritos nos seguintes tópicos: percepções sobre o processo de AIA, percepções sobre a participação pública e percepções sobre a participação pública no processo de AIA do Rodoanel.

As limitações deste trabalho estão relacionadas com o índice de resposta da pesquisa survey, com a inviabilidade em acessar integralmente todos os volumes dos processos de Licenciamento do caso escolhido devido à grande quantidade de informações, com a impossibilidade de analisar todos os documentos dos processos disponibilizados dentro do recorte, por conta do tempo disponível para realizar uma pesquisa de mestrado. Outra limitação foi a dificuldade de contatar diversos atores para realizar as entrevistas. No entanto, apesar destas limitações, os objetivos da pesquisa puderam ser alcançados e todos os grupos de partes interessadas foram contemplados no delineamento da pesquisa. 


\section{RESULTADOS E DISCUSSÃO}

Neste capítulo, serão apresentados os resultados desta pesquisa de modo a descrever e analisar a participação pública no processo de AIA no estado de São Paulo, a partir do caso selecionado. A primeira parte dos resultados apresenta como se chegou no caso de estudo e as percepções dos atores sobre o que é um caso participativo. Na segunda parte, será apresentado os levantamentos sobre o estudo de caso do Rodoanel Metropolitano de São Paulo, contemplando o histórico do processo de AIA do empreendimento, o mapeamento dos atores envolvidos neste processo e a descrição sobre a participação pública neste caso, levando em consideração as percepções dos atores e as evidências encontradas no processo.

O mapa da dissertação com todas as etapas percorridas para encontrar os resultados está representado na Figura 8. 
Figura 8 - Mapa da dissertação

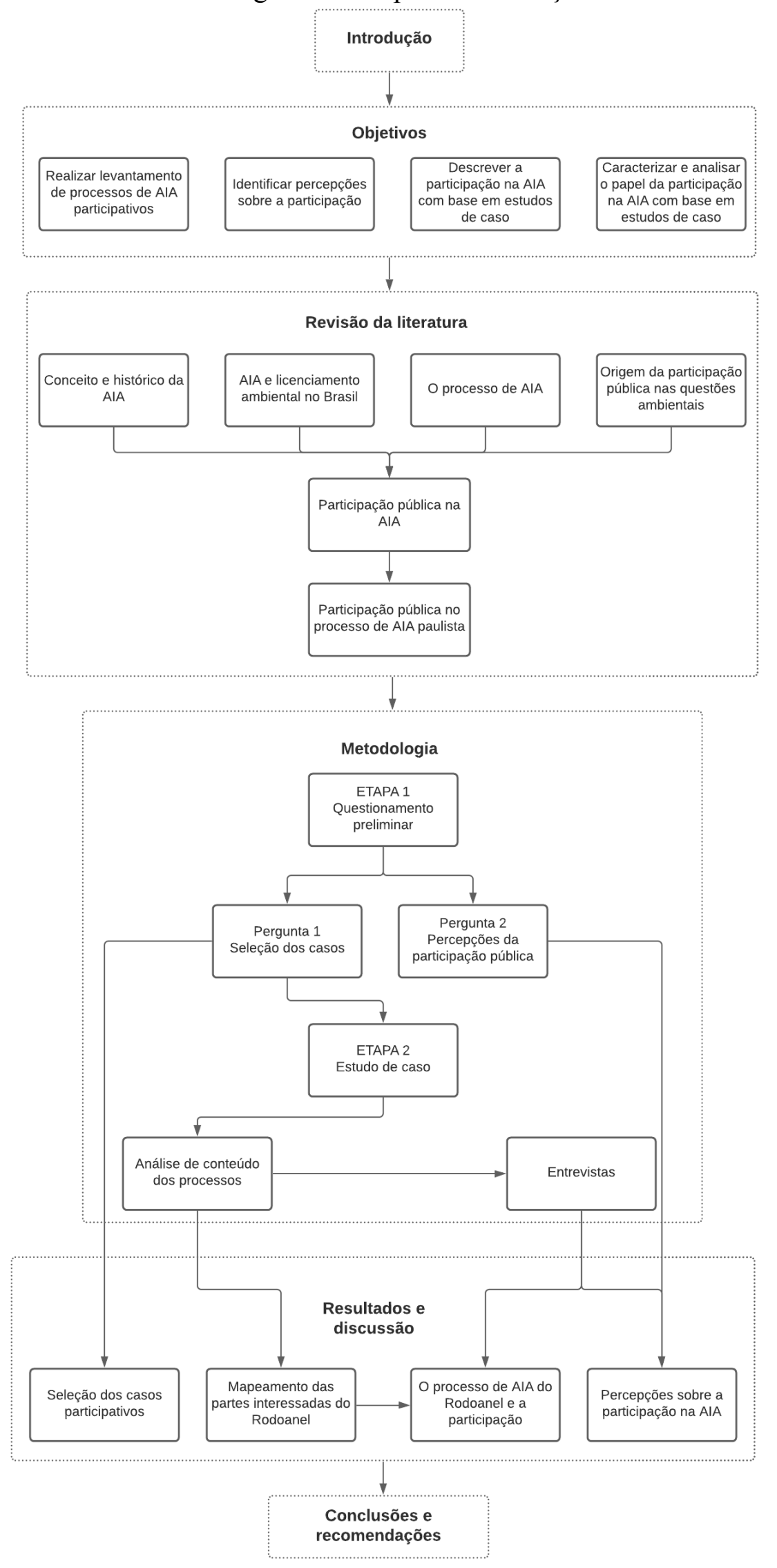

Fonte: Elaborado pela autora 


\subsection{Questionamento preliminar}

Foram contatados 341 possíveis atores envolvidos com a AIA. Dentre eles, apenas 23 respostas puderam ser apuradas, representando uma taxa de retorno 6,45\%. Apesar de baixa, foram suficientes para a finalidade da sua aplicação.

As respostas do questionamento preliminar foram organizadas por grupos de atores, sendo que o grupo 1 representa os pesquisadores da área, o grupo 2 representa atores que compõe o quadro de funcionários do órgão ambiental, o grupo 3 representa os membros de ONGs, conselhos, instituições públicas e membros da sociedade, e o grupo 4 representa as consultorias ambientais. A divisão das respostas obtidas por cada grupo é apresentada na Tabela 9.

Tabela 9 - Número de entrevistados

\begin{tabular}{ccccc}
\hline \multicolumn{4}{c}{ Número de entrevistados } \\
\hline $\begin{array}{c}\text { Grupo 1 } \\
\text { Pesquisadores }\end{array}$ & $\begin{array}{c}\text { Grupo 3 } \\
\text { Orupo 2 } \\
\text { Ombiental }\end{array}$ & $\begin{array}{c}\text { ONGs } \\
\text { conselhos e } \\
\text { órgãos públicos } \\
\text { e sociedade } \\
\text { civil }\end{array}$ & $\begin{array}{c}\text { Grupo 4 } \\
\text { Consultoria } \\
\text { ambiental }\end{array}$ & Total \\
\hline 8 & 3 & 3 & 9 & 23 \\
\hline
\end{tabular}

Fonte: Elaborado pela autora

\subsubsection{Seleção dos casos participativos}

As respostas da pergunta 1 - Você se lembra de algum(ns) caso(s) em que a Participação Pública teve destaque no processo de AIA do estado de São Paulo? - foram contabilizadas e utilizadas como critério para seleção do estudo de caso da segunda etapa. As respostas com os casos citados pelos atores e o grupo ao qual cada um deles pertence está na Figura 9.

Foram 25 casos citados pelo grupo de pesquisadores, 7 casos pelo grupo de atores do órgão ambiental, 6 casos pelo grupo de membros de ONGs, conselhos, órgãos públicos e sociedade civil e 14 casos pelo grupo das consultorias ambientais. Dentre estes, 8 casos foram citados mais do que uma vez e 6 casos foram citados por mais de um grupo de atores. Os casos que foram citados por mais de um grupo de atores contemplam: ampliação do porto de São Sebastião, Incinerador São Caetano do Sul, Poliduto (Paulínia-Brasília), duplicação da rodovia Raposo Tavares, Usina Termo Elétrica - UTE Carioba II e Rodoanel Mário Covas. 
Figura 9 - Casos de Licenciamento Ambiental citados no questionamento preliminar

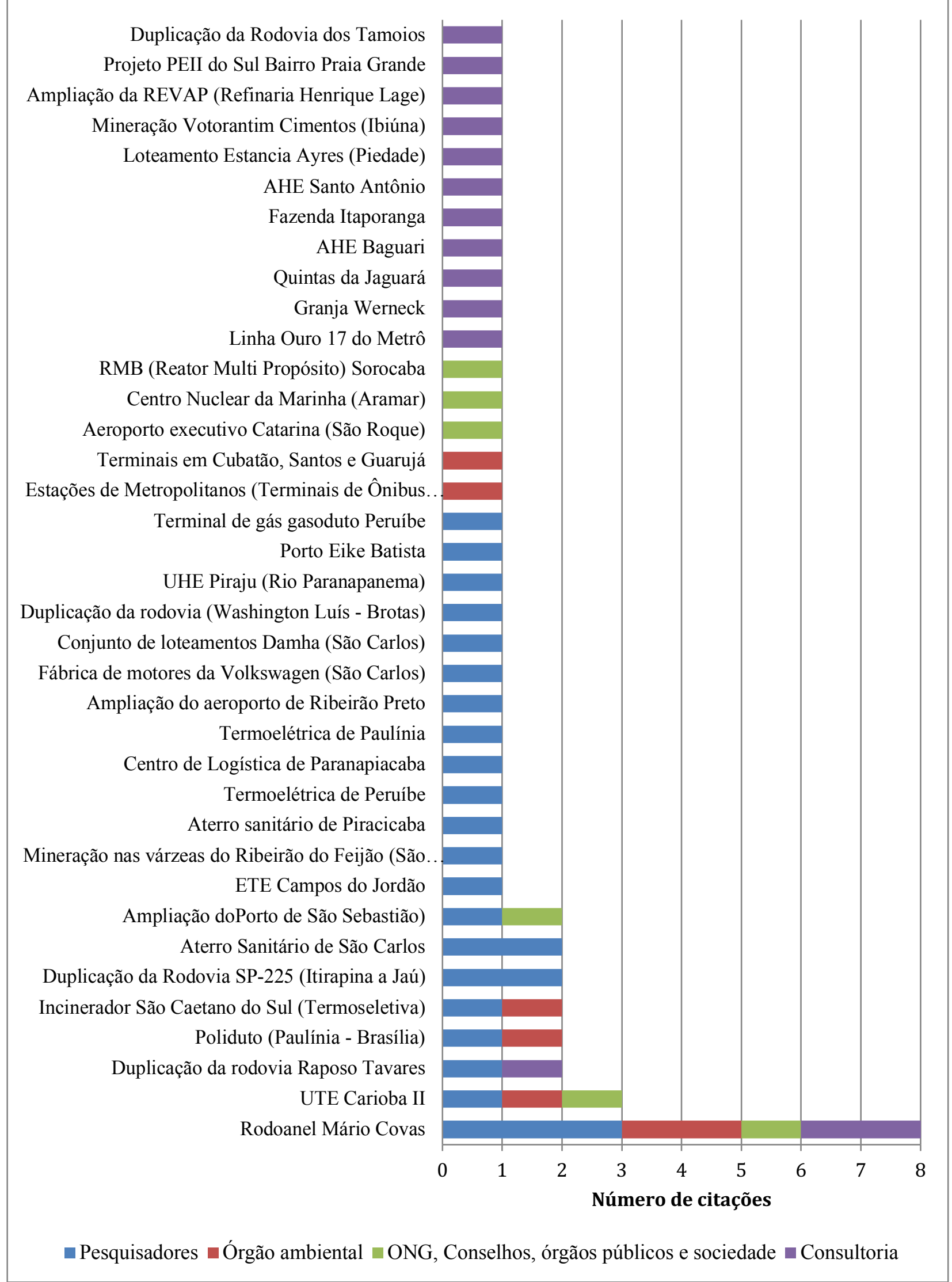

Fonte: Elaborado pela autora. 
No entanto, o caso que teve maior destaque por ser mais o citado entre os atores e que foi contemplado por todos os grupos foi o Rodoanel Metropolitano de São Paulo. Apesar de ser um só empreendimento, o processo de licenciamento do Rodoanel foi dividido em quatro trechos (Norte, Sul, Leste e Oeste) e cada ator citou o caso se referindo ao empreendimento de forma diferente. Alguns especificaram o trecho ao qual se referiam e outros não. Uma relação do número de atores e os grupos que citaram o caso do Rodoanel estão apresentados na Tabela 10.

Tabela 10 - Atores que citaram o Rodoanel

\begin{tabular}{|c|c|c|c|c|c|c|}
\hline & \multirow[b]{2}{*}{ Lista de casos } & \multicolumn{4}{|c|}{ Quem citou? } & \multirow[b]{2}{*}{ Total } \\
\hline & & $\begin{array}{c}\text { Grupo } 1 \\
\text { Pesquisadores }\end{array}$ & $\begin{array}{c}\text { Grupo } 2 \\
\text { Órgão } \\
\text { ambiental }\end{array}$ & $\begin{array}{l}\text { Grupo } 3 \\
\text { ONGs, } \\
\text { conselhos, } \\
\text { órgãos } \\
\text { públicos e } \\
\text { sociedade } \\
\text { civil }\end{array}$ & $\begin{array}{c}\text { Grupo } 4 \\
\text { Consultoria } \\
\text { ambiental }\end{array}$ & \\
\hline \multirow{5}{*}{$\begin{array}{l}\bar{\Phi} \\
\tilde{\Xi} \\
0 \\
0 \\
0 \\
\simeq\end{array}$} & Norte & 1 & & & & \multirow{5}{*}{8} \\
\hline & Sul & & 1 & & & \\
\hline & Leste & & $1^{*}$ & & & \\
\hline & Oeste & & 1 & & & \\
\hline & $\begin{array}{c}\text { Não } \\
\text { especificou }\end{array}$ & 2 & & 1 & 2 & \\
\hline
\end{tabular}

Legenda: * citado pelo mesmo ator que citou o Rodoanel Trecho Sul.

Fonte: Elaborado pela autora.

Depois de selecionar o caso a ser estudado, entrou-se em contato com o órgão ambiental para agendar as vistas aos processos, neste momento, o órgão informou que os quatro processos dos Trechos Oeste, Sul, Leste e Norte do Rodoanel possuíam cerca de 300 a 400 volumes cada. Por conta da grande quantidade de documentos, a análise integral de todos os processos de todos os trechos do caso do Rodoanel seria impraticável. Considerando estes motivos, optou-se por analisar os quatro processos dos quatro trechos do Rodoanel até a emissão da licença prévia (LP). Após determinar este recorte, foi solicitado ao órgão ambiental o agendamento para realização da consulta e os processos foram disponibilizados no formato impresso e contemplavam os volumes desde a publicação do EIA/RIMA até a emissão da LP. Mais detalhes sobre os volumes analisados e os resultados referentes ao estudo de caso do Rodoanel estão detalhados no item 5.2. 


\subsubsection{Percepções da participação pública}

As respostas referentes à pergunta 2 - Por que você considera que a participação neste processo foi notória? - foram utilizadas para identificar os motivos pelos quais um ator envolvido com a AIA considera um processo participativo.

Para auxiliar na análise das respostas da pergunta 2 foi utilizado o software IRAMUTEQ, iniciando com uma análise lexicográfica clássica. Dos 23 atores que participaram do questionamento preliminar, foram consideradas 21 respostas, ou seja, 21 segmentos de texto, pois 2 deles não responderam a segunda pergunta.

Após realizar a análise estatística do corpus textual, foi gerada uma nuvem de palavras. Para este segundo processamento dos dados foram excluídas palavras de classes gramaticais como artigos, preposições, conjunções e verbos que tinham uma alta frequência no texto, mas não exprimiriam significado relevante para interpretação da análise. A nuvem de palavras destacou os termos mais utilizados pelos atores para caracterizar um caso participativo (Figura 10).

Figura 10 - Nuvem de palavras do questionamento preliminar: Por que você considera que a participação neste processo foi notória?

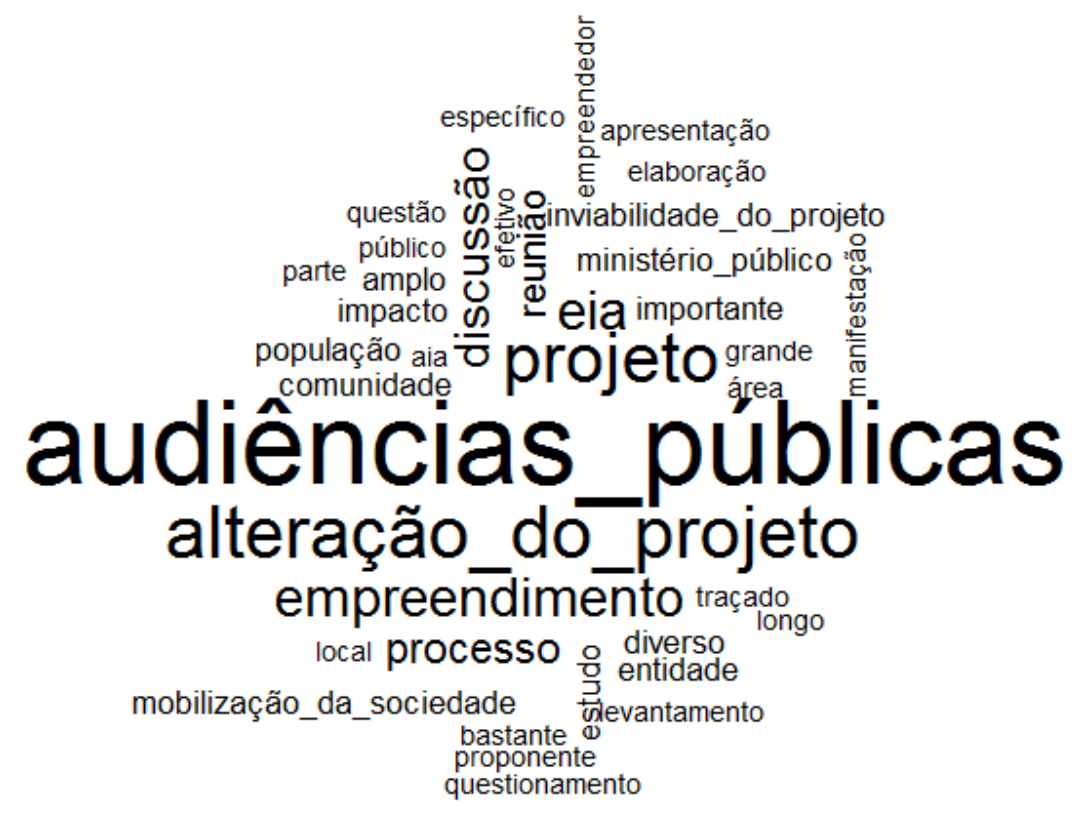

Fonte: Elaborado pela autora.

Os termos que aparecem na nuvem de palavras foram citados três vezes ou mais em todas as respostas processadas. Expressões como "mobilização da sociedade", "ministério público", "inviabilidade do projeto" se repetiram 4 vezes e a expressão "reunião" foi citada 5 vezes. A palavra "discussão" apareceu 7 vezes, e a sigla "EIA" 8 vezes. As expressões que 
tiveram maior destaque nos resultados sobre as percepções dos atores foram "alteração do projeto" citada 12 vezes e "audiências públicas" citada 20 vezes.

Os resultados mostram que os atores que responderam ao questionamento fizeram uma associação da participação pública na AIA com a capacidade do público de se mobilizar, com a atuação do Ministério Público no processo, com a realização de reuniões e discussões e também com o fato de a participação ser vinculada à alteração ou mesmo à inviabilização de um projeto. O aparecimento da sigla "EIA" de forma mais recorrente se justifica pelas citações ao estudo do caso citado, pelos atores associarem a participação ao momento de análise do EIA, ou sobre a participação ter levado à necessidade de reelaborar/complementar o EIA. A alteração do projeto foi a segunda expressão mais citada e pode estar associada com a percepção dos atores de que uma participação pública é considerada significativa quando resulta em alguma forma de alteração no projeto. $\mathrm{O}$ aparecimento frequente das audiências públicas nas respostas pode estar relacionado à imediata associação que as pessoas fazem do instrumento com a participação pública.

Como estes resultados se relacionam diretamente com os resultados referentes as percepções da participação dos atores do caso do Rodoanel que serão apresentadas no tópico 5.4, a discussão será realizada de forma conjunta ao final do trabalho.

\subsection{Mapeamento das partes interessadas do Rodoanel}

Durante a análise documental e de conteúdo dos volumes dos processos dos quatro trechos do Rodoanel foi realizado o mapeamento dos atores que participaram de alguma forma. Os atores foram identificados pelos nomes publicados nos documentos dos processos dos Trechos Oeste, Sul, Leste e Norte que foram disponibilizados. A Figura 11 mostra os atores e em quais trechos eles foram identificados. 
Figura 11 - Mapa dos atores envolvidos nos processos de Licenciamento com AIA dos quatro trechos do Rodoanel

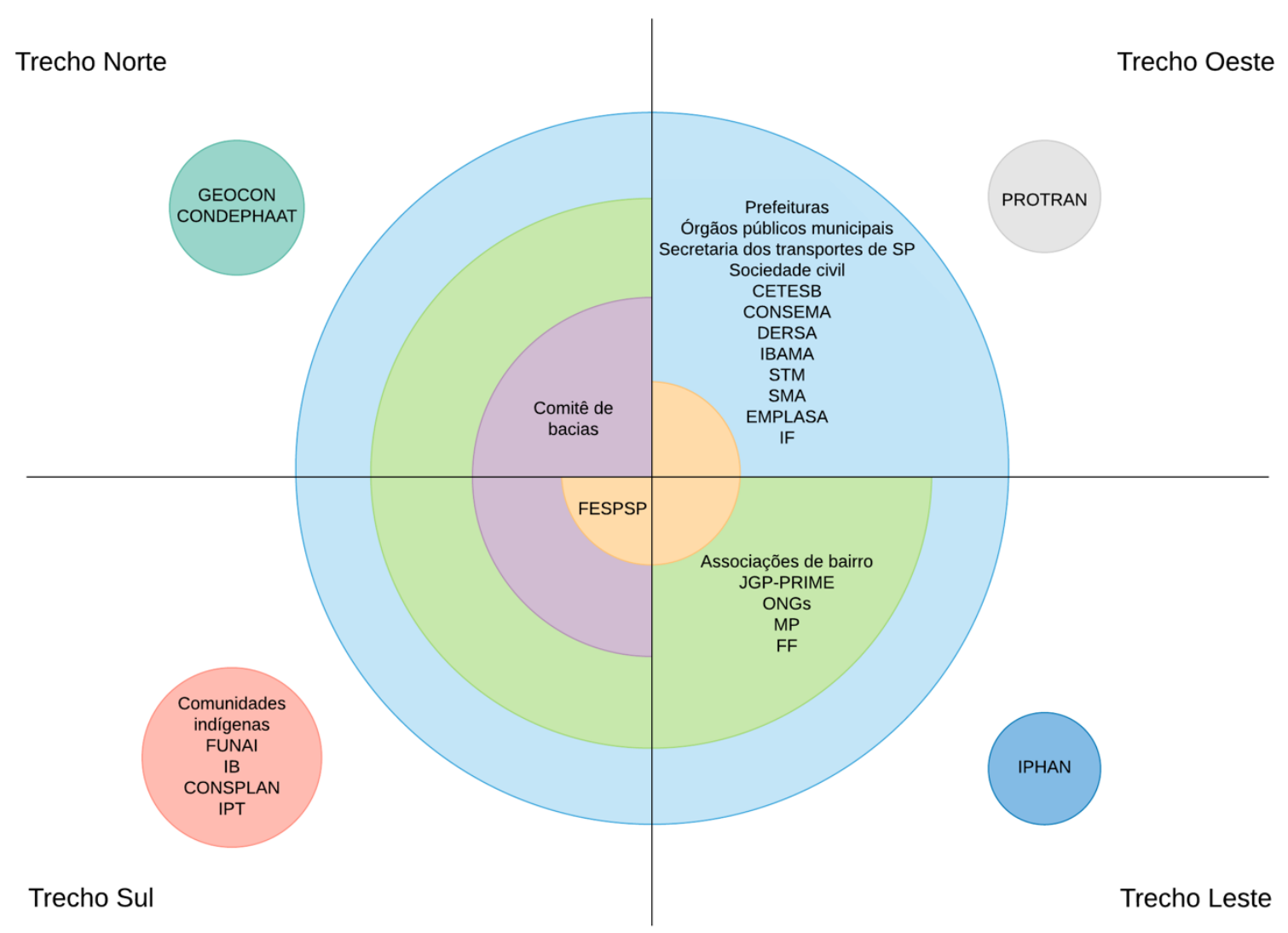

Fonte: Elaborado pela autora.

Os nomes dos atores que aparecem nos círculos menores e fechados nas extremidades do gráfico estiveram presentes em apenas um dos processos analisados. Por exemplo, as comunidades indígenas, Fundação Nacional do Índio (FUNAI), Instituto Biológico (IB), a consultoria ambiental CONSPLAN e o Instituto de Pesquisas Tecnológicas (IPT) representadas pelo círculo vermelho, puderam ser identificadas nos documentos analisados apenas no Trecho Sul do Rodoanel. Os fragmentos de círculo na cor laranja no centro do diagrama mostram que a Fundação Escola de Sociologia e Política do Estado de São Paulo (FESPSP) foi identificada nos processos do Trecho Oeste, Sul e Leste. Já o semicírculo na cor roxa representa os Comitês de bacias, identificados nos processos dos Trechos Norte e Sul. Os atores JGP-PRIME (consultoria ambiental), Organizações não governamentais (ONGs), Ministério Público (MP) e Fundação Florestal (FF) puderam ser encontrados em documentos de três processos, Norte, Sul e Leste. Já os atores que estão dentro do círculo maior de cor azul apareceram nos quatro processos dos quatro trechos do Rodoanel, que é o caso da prefeituras dos municípios envolvidos, órgãos públicos municipais, Secretaria dos 
transportes de São Paulo, sociedade civil, CETESB, CONSEMA, Desenvolvimento Rodoviário S/A (DERSA), Instituto Brasileiro do Meio Ambiente e dos Recursos Naturais Renováveis (IBAMA), Secretaria de Estado dos Transportes Metropolitanos (STM), Secretaria do Meio Ambiente (SMA), Empresa Paulista de Planejamento Metropolitano S/A (EMPLASA), Instituto Florestal (IF).

O fato de um ator não aparecer no mapeamento realizado não significa que ele não participou do processo de AIA do Rodoanel, mas que não foi identificado pela pesquisadora nos documentos disponibilizados para análise. Com tudo, esta limitação não reduz a importância do mapeamento realizado, que apresenta os principais atores envolvidos.

Após o mapeamento dos atores, os nomes dos indivíduos vinculados às instituições foram identificados nos documentos e foram organizados em quatro grupos. O grupo A é composto por membros do órgão ambiental e do CONSEMA, o grupo B é composto por membros da consultoria ambiental e do DERSA, o grupo C contempla os representantes das instituições públicas e o grupo D representa a sociedade civil. Vale destacar que estes grupos definidos são diferentes daqueles utilizados no questionário preliminar (para não haver confusão, naquele lugar são apresentados por números e, aqui, por letras).

Após identificar os atores envolvidos nos processos dos Trechos Oeste, Sul, Leste e Norte do Rodoanel, iniciou-se a busca por formas de contato dos possíveis entrevistados. O número de atores mapeados, o número de entrevistados e a quais grupos eles pertenciam estão retratados na Tabela 11 .

É possível observar que foram mapeados 174 atores, mas somente 9 foram entrevistados. Os atores dos Grupos A (órgão ambiental e CONSEMA) e C (Poder público) foram mais fáceis de identificar e contatar. Os contatos referentes aos nomes pertencentes ao Grupo C (poder público) foram conseguidos quase que em sua totalidade por meio de indicação de terceiros, representando a maior amostra de entrevistados dentre todos os grupos. Também houve dificuldade em mapear e contatar integrantes dos Grupos B (Consultoria Ambiental/DERSA) e D (Sociedade civil).

Apesar do número de entrevistados não ser alto devido a todas as limitações apontadas, foram contemplados integrantes de todos os grupos de partes interessadas e dos diferentes trechos do Rodoanel. A Tabela 12 apresenta uma relação de todos os atores entrevistados e de quais trechos cada um deles participou. 
Tabela 11 - Quantidade de atores mapeados e entrevistados

\begin{tabular}{|c|c|c|c|c|c|}
\hline Atores & $\begin{array}{c}\text { Grupo A } \\
\text { Órgão } \\
\text { ambiental/ } \\
\text { CONSEMA }\end{array}$ & $\begin{array}{c}\text { Grupo B } \\
\text { Consultoria } \\
\text { ambiental/ } \\
\text { DERSA }\end{array}$ & $\begin{array}{c}\text { Grupo C } \\
\text { Poder } \\
\text { público }\end{array}$ & $\begin{array}{c}\text { Grupo D } \\
\text { Sociedade } \\
\text { civil }\end{array}$ & $\underset{\substack{\Sigma \\
\text { trechor } \\
\text { trecho }}}{ }$ \\
\hline \multicolumn{6}{|c|}{ Trecho Oeste } \\
\hline Mapeados & 9 & 14 & 11 & 0 & 34 \\
\hline Entrevistados & 2 & 0 & 2 & 0 & 4 \\
\hline \multicolumn{6}{|c|}{ Trecho Sul } \\
\hline Mapeados & 7 & 10 & 16 & 24 & 57 \\
\hline Entrevistados & 2 & 1 & 3 & 1 & 7 \\
\hline \multicolumn{6}{|c|}{ Trecho Leste } \\
\hline Mapeados & 9 & 4 & 14 & 8 & 35 \\
\hline Entrevistados & 2 & 1 & 2 & 0 & 5 \\
\hline \multicolumn{6}{|c|}{ Trecho Norte } \\
\hline Mapeados & 8 & 9 & 15 & 16 & 48 \\
\hline Entrevistados & 2 & 1 & 2 & 0 & 5 \\
\hline \multicolumn{6}{|c|}{ Total de atores por grupo } \\
\hline Mapeados & 33 & 37 & 56 & 48 & 174 \\
\hline Entrevistados & 2 & 1 & 5 & 1 & $9 *$ \\
\hline $\begin{array}{r}* \mathrm{As} \\
\text { original }\end{array}$ & $\begin{array}{l}\text { atória do total } \\
\text { is vários dos a }\end{array}$ & $\begin{array}{l}\text { ores entrevista } \\
\text { identificados a } \\
\text { enciamento/A }\end{array}$ & $\begin{array}{l}\text { grupo é m } \\
\text { l em mais c } \\
\text { Rodoanel. }\end{array}$ & $\begin{array}{l}\text { r do que a sol } \\
\mathrm{n} \text { trecho do } \mathrm{p}\end{array}$ & $\begin{array}{l}\text { tória } \\
\text { cesso de }\end{array}$ \\
\hline
\end{tabular}

Tabela 12 - Relação de entrevistados

\begin{tabular}{ccc}
\hline $\begin{array}{c}\text { Código de } \\
\text { identificação }\end{array}$ & Grupo & Trecho \\
\hline A1 & $\begin{array}{c}\text { GRUPO A: Órgão } \\
\text { ambiental/CONSEMA }\end{array}$ & $\begin{array}{c}\text { OESTE, SUL, } \\
\text { LESTE, NORTE }\end{array}$ \\
\hline A2 & $\begin{array}{c}\text { GRUPO A: Órgão } \\
\text { ambiental/CONSEMA }\end{array}$ & $\begin{array}{c}\text { OESTE, SUL, } \\
\text { LESTE, NORTE }\end{array}$ \\
\hline B1 & $\begin{array}{c}\text { GRUPO B: Consultoria } \\
\text { ambiental/DERSA }\end{array}$ & $\begin{array}{c}\text { SUL, LESTE, } \\
\text { NORTE }\end{array}$ \\
\hline C1 & GRUPO C: Poder público & OESTE \\
\hline C2 & GRUPO C: Poder público & $\begin{array}{c}\text { SUL, LESTE, } \\
\text { NORTE }\end{array}$ \\
\hline C3 & GRUPO C: Poder público & $\begin{array}{c}\text { SUL, LESTE, } \\
\text { NORTE }\end{array}$ \\
\hline C4 & GRUPO C: Poder público & SUL \\
\hline C5 & GRUPO C: Poder público & OESTE \\
\hline D1 & GRUPO D: Sociedade civil & SUL
\end{tabular}

Fonte: Elaborado pela autora. 


\subsection{O processo de AIA do Rodoanel e a participação}

Nesta seção, será apresentada a caracterização do projeto do Rodoanel e, em seguida, será realizada uma descrição dos processos de Licenciamento com AIA dos Trechos Oeste, Sul, Leste e Norte, em ordem cronológica, considerando as evidências da participação documentada e as respostas da pergunta 4 (itens a, b, c) do roteiro de entrevistas (Apêndice A). Também foram usadas nesta descrição alguns trabalhos acadêmicos sobre o projeto do Rodoanel.

\subsubsection{Caracterização do projeto}

O Rodoanel Mário Covas está localizado no estado de São Paulo, na região metropolitana da cidade de São Paulo, também conhecida como RMSP, que consiste na maior aglomeração urbana do país com 21,9 milhões de habitantes (IBGE, 2020a). A RMSP é composta por 39 municípios divididos em 5 sub-regiões: Norte (Caieiras, Cajamar, Francisco Morato, Franco da Rocha e Mairiporã), Leste (Arujá, Biritiba-Mirim, Ferraz de Vasconcelos, Guararema, Guarulhos, Itaquaquecetuba, Mogi das Cruzes, Poá, Salesópolis, Santa Isabel e Suzano), Sudeste (Diadema, Mauá, Ribeirão Pires, Rio Grande da Serra, Santo André, São Bernardo do Campo e São Caetano do Sul), Sudoeste (Cotia, Embu, Embu-Guaçu, Itapecerica da Serra, Juquitiba, São Lourenço da Serra, Taboão da Serra e Vargem Grande Paulista) e Oeste (Barueri, Carapicuíba, Itapevi, Jandira, Osasco, Pirapora do Bom Jesus e Santana de Parnaíba) (EMPLASA, 2020). O município de São Paulo é a capital do estado e está localizado no centro da RMSP e, de acordo com o IBGE (2020a), continua sendo o mais populoso do país, com 12,3 milhões de habitantes. A Figura 12 mostra as cidades e subregiões que compreendem a RMSP e também a cidade de São Paulo.

A frota de veículos da RMSP chega a 5 milhões de carros, ônibus e caminhões e, além disso, a malha rodoviária de todo o estado de São Paulo converge para a capital (SÁNCHEZ; SILVA-SÁNCHEZ, 2008), sendo a população estadual estimada de 46 milhões de habitantes (IBGE, 2020b). A maneira como essa malha rodoviária foi desenhada acabava por aumentar o tráfego de veículos que, muitas vezes, não tinham como destino a RMSP, mas que acabavam por cruzá-la em direção a outro destino, principalmente o porto marítimo de Santos (SÁNCHEZ; SILVA-SÁNCHEZ, 2008). O porto de Santos é o maior complexo portuário da América Latina e é responsável por movimentar cerca de 30\% das trocas comerciais brasileiras (CODESP, 2020). 
Figura 12 - Região metropolitana de São Paulo

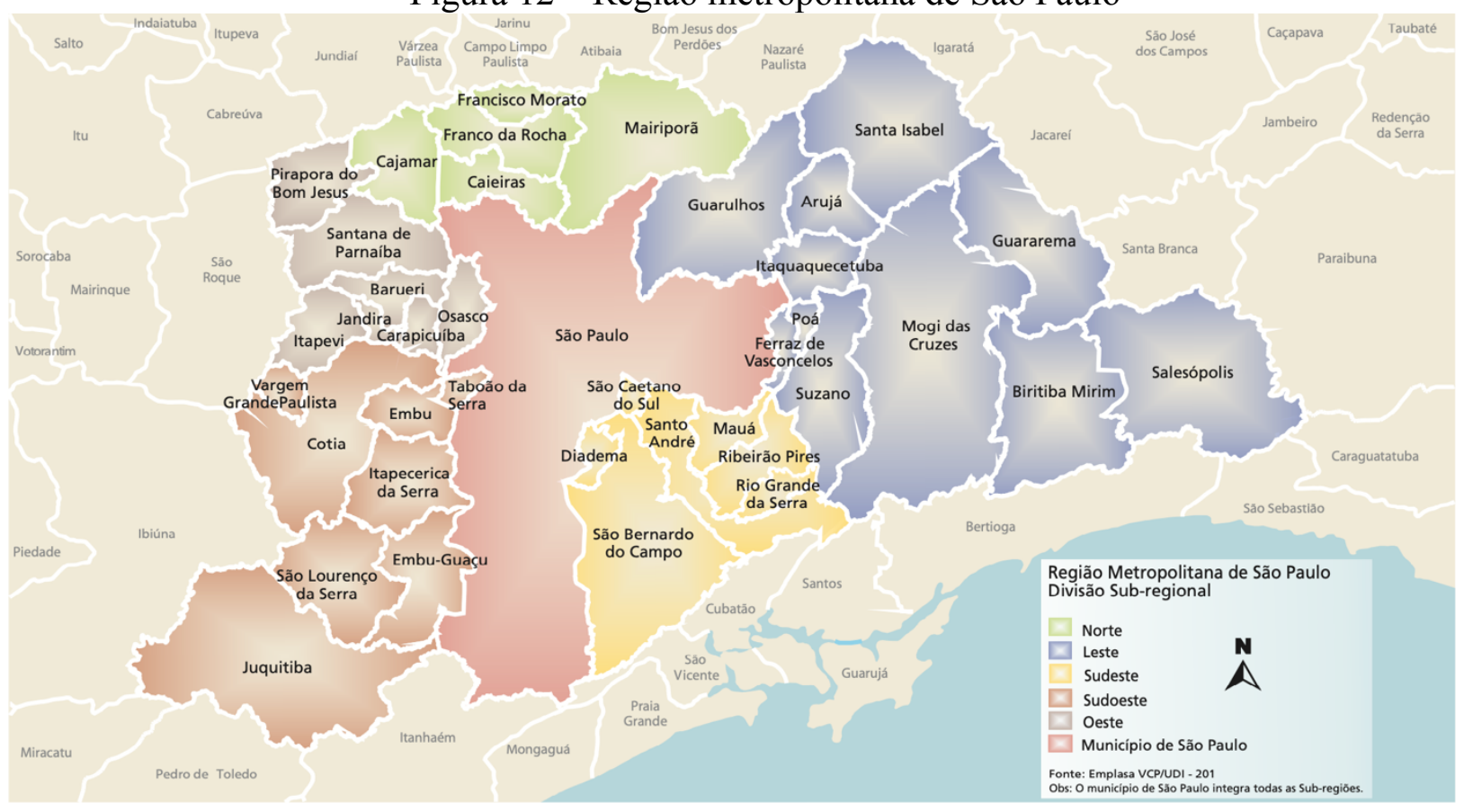

Fonte: EMPLASA, 2011.

A complexidade da RMSP tem implicações além dos limites de seu território e com o objetivo de melhorar as condições de vida das pessoas dessa região, foram direcionados investimentos públicos visando aumentar o acesso à infraestrutura e serviços urbanos e um dos projetos investidos foi o do Rodoanel Mário Covas (MOTTA; MIRANDA, 2013).

Antes de o Rodoanel ser concebido como é atualmente, outras alternativas já haviam sido idealizadas por outros estudos que propunham a construção de um anel viário, como por exemplo, o Plano de Avenidas de Prestes Maia em 1930, a implantação das marginais Tietê e Pinheiros (IACOVINI, 2015), a Via Perimetral Metropolitana (VPM), em 1989, e a Via de Ligação Rodoviária (VIR), em 1991 (FESPSP, 2004).

O projeto do Rodoanel na totalidade começou a ser estudado no início da década de 1990 pela DERSA, a qual enviou uma carta para a CETESB com uma minuta para realização de um convênio de cooperação técnica entre os órgãos, de modo a considerar a necessidade de controlar a emissão de poluentes atmosféricos provenientes de veículos de transporte de carga e passageiros nas estradas, bem como da qualidade da água dos mananciais cortados pelas rodovias sob jurisdição da DERSA. A partir disso, a DERSA elaborou diversos estudos como o estudo de alternativas para o Rodoanel e o estudo de variantes de traçado em 1992, e os estudos de traçado para o trecho entre as rodovias Castello Branco e Bandeirantes e para a Serra da Cantareira em 1994 (FESPSP, 2004). 
Em agosto de 1996, foi assinado um Termo de Cooperação entre a Secretaria de Estado dos Transportes, a Secretaria dos Transportes Metropolitanos (STM) e a Secretaria de Estado do Meio Ambiente (SMA) que tinha como finalidade estabelecer as condições de ação do governo para a elaboração do projeto e implementação do Rodoanel. Neste termo, foram estabelecidas as responsabilidades de cada uma das entidades envolvidas, sendo que a Secretaria de Estado dos Transportes ficaria encarregada de realizar uma avaliação estratégica de transportes estabelecendo diretrizes relativas à política institucional de transportes de cargas, à racionalização do tráfego de cargas de passagem, à intermodalidade rodoferroviária, à logística de transporte e também realizando uma avaliação da viabilidade técnica e econômica do Rodoanel e da participação da iniciativa privada. Para a STM coube a realização de uma avaliação estratégica de desenvolvimento integrado metropolitano, considerando a ordenação e ocupação do solo e o transporte metropolitano intermodal e a SMA incumbiu-se de realizar uma avaliação estratégica ambiental, assim chamada nos documentos do processo, de modo a estabelecer diretrizes para a política de conservação ambiental dos recursos hídricos, áreas florestais e qualidade de vida urbana. Todas essas ações deveriam considerar o projeto do Rodoanel na totalidade, apesar de o documento orientar que o projeto do Rodoanel deveria ser segmentado de modo a permitir sua implantação por etapas.

As avaliações citadas anteriormente foram apresentadas e, nesta época, idealizaram o projeto do Rodoanel em 3 trechos, denominados: Trecho 1, com 43,9 km a ser construído pelo estado com recursos públicos e privados; Trecho 2 com 85,4 km; e Trecho 3 com 49,6 $\mathrm{km}$ a serem construídos pela iniciativa privada com recursos financeiros gerados pela receita do próprio empreendimento. A divisão da primeira versão do projeto do Rodoanel está mostrada na Figura 13. Posteriormente, esta concepção do projeto seria mudada para quatro trechos, onde cada um seria nomeado de acordo com sua localização na RMSP: Trechos Norte, Sul, Leste e Oeste.

A justificativa apresentada para a construção do Rodoanel era que ele representava uma importante alternativa ao tráfego de carga de passagem na RMSP favorecendo a intermodalidade; desta forma, o Rodoanel resolveria o conflito entre o transporte urbano e o de cargas que, até o momento, era considerado o motivo dos congestionamentos nas principais vias urbanas. A intermodalidade representava uma conexão com o projeto do ferroanel, que tinha como objetivo separar o fluxo de trens de carga do fluxo de trens de passageiros. Diversos projetos desde a década de 1950 até os dias atuais foram apresentados a cada plano criado pelos governo federal ou estadual para desafogar o chamado "gargalo 
logístico" da RMSP, mas o ferroanel nunca foi implementado como uma obra completa (OLIVEIRA, 2014).

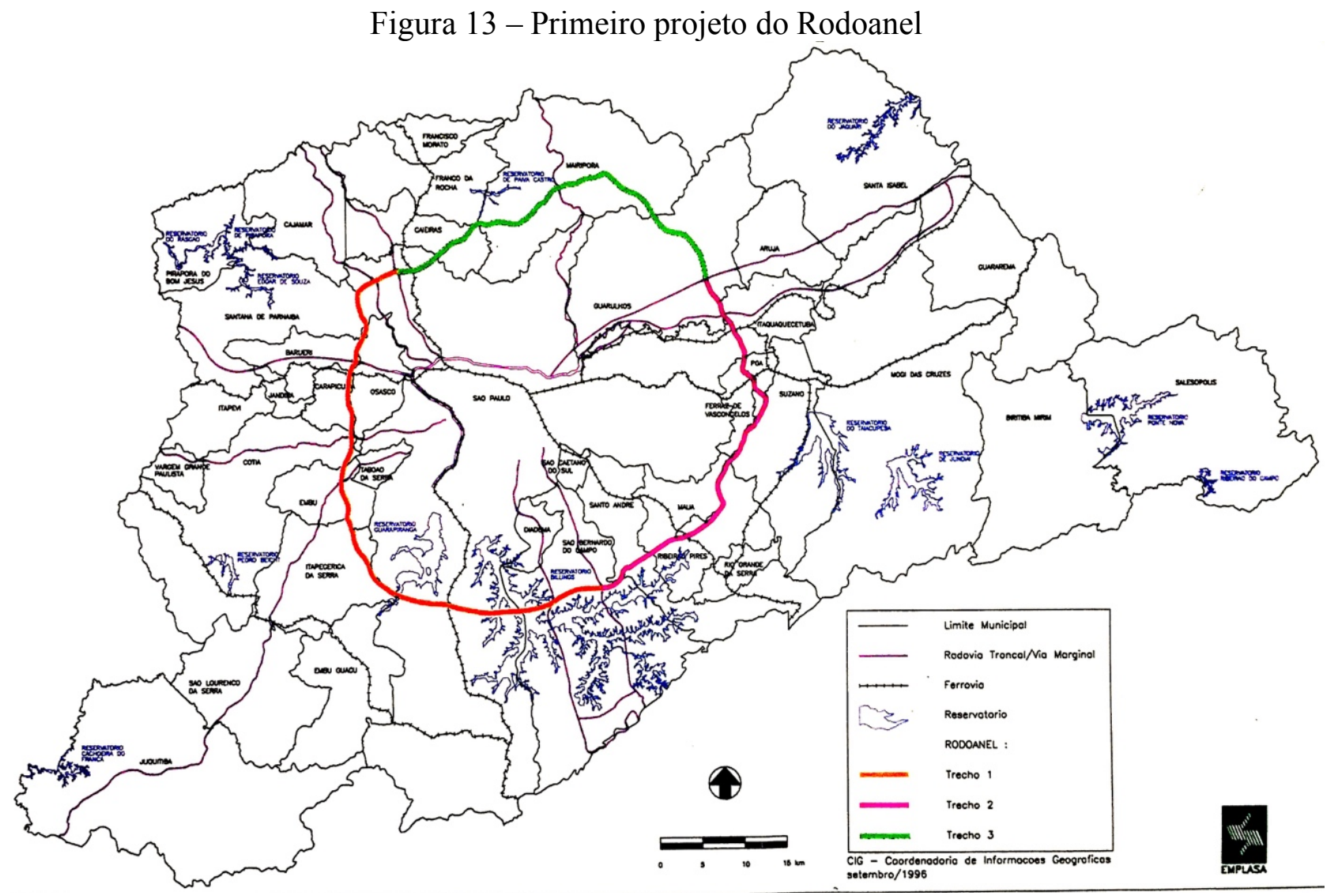

Fonte: EMPLASA, 1996

No caso do Rodoanel, o primeiro trecho a dar início ao processo de licenciamento ambiental foi o Oeste em 1997, seguido pelo Sul em 2004, Leste em 2009 e Norte em 2010. $\mathrm{Na}$ Tabela 13 estão organizados os principais dados referentes aos processos analisados e os municípios da RMSP que cada um dos trechos atravessou.

De acordo com documentos do processo, o Trecho Oeste foi o primeiro trecho a ser licenciado, pois havia uma previsão de maior carregamento de tráfego neste segmento, o que representava um benefício maior na época quando comparado aos outros trechos isoladamente. Outro motivo é que o Trecho Oeste tinha menor extensão e interligaria uma maior quantidade de rodovias e, por fim, ele possuía menor quantidade de opções viáveis de traçado, o que poderia aumentar a possibilidade de serem inviabilizadas a curto prazo por conta do rápido processo de expansão urbana na área. Percebe-se também a complexidade do empreendimento e, por consequência, do seu processo de licenciamento que foi apoiado em AIA. 
Tabela 13 - Identificação dos processos do Rodoanel

\begin{tabular}{|c|c|c|c|c|}
\hline Rodoanel & Trecho Oeste & Trecho Sul & Trecho Leste & Trecho Norte \\
\hline Processo/ano & $13.522 / 1997$ & $13.730 / 2004$ & $6.563 / 2009$ & $208 / 2010$ \\
\hline Municípios & $\begin{array}{c}\text { Embu, Cotia, } \\
\text { Carapicuíba, } \\
\text { Osasco, } \\
\text { Barueri, São } \\
\text { Paulo }\end{array}$ & $\begin{array}{c}\text { São Paulo, } \\
\text { Ribeirão Pires, } \\
\text { Mauá, Santo } \\
\text { André, São } \\
\text { Bernardo do } \\
\text { Campo, } \\
\text { Itapecerica da } \\
\text { Serra e Embú }\end{array}$ & $\begin{array}{c}\text { Arujá, } \\
\text { Itaquaquecetuba, } \\
\text { Mauá, Ribeirão } \\
\text { Pires, Poá e } \\
\text { Suzano }\end{array}$ & $\begin{array}{l}\text { São Paulo, } \\
\text { Guarulhos, } \\
\text { Arujá }\end{array}$ \\
\hline Extensão & $32 \mathrm{~km}$ & $61 \mathrm{~km}$ & $43,5 \mathrm{~km}$ & $42,8 \mathrm{~km}$ \\
\hline $\begin{array}{c}\text { Rodovias } \\
\text { interligadas }\end{array}$ & $\begin{array}{c}\text { Anhanguera, } \\
\text { Bandeirantes, } \\
\text { Castelo Branco, } \\
\text { Raposo Tavares } \\
\text { e Régis } \\
\text { Bittencourt }\end{array}$ & $\begin{array}{l}\text { Imigrantes e } \\
\text { Anchieta }\end{array}$ & $\begin{array}{l}\text { Ayrton Senna e } \\
\text { Dutra }\end{array}$ & $\begin{array}{l}\text { Av. Inajar de } \\
\text { Souza, Fernão } \\
\text { Dias e ligação } \\
\text { com o } \\
\text { Aeroporto de } \\
\text { Guarulhos }\end{array}$ \\
\hline Volumes & Caixa 1,2 e 3 & XXIV a XLI & XVIII a XXXV & XVI a XXXVI \\
\hline $\begin{array}{l}\text { Relatório } \\
\text { Ambiental } \\
\text { Preliminar } \\
\text { (RAP) }\end{array}$ & Abril/1997 & - & - & - \\
\hline $\begin{array}{l}\text { Termo de } \\
\text { Referência }\end{array}$ & Maio/1997 & $*$ & $*$ & $*$ \\
\hline EIA/RIMA & Setembro/1997 & $\begin{array}{c}\text { Maio/2002 } \\
\text { (EIA dos } \\
\text { trechos } \\
\text { remanescentes: } \\
\text { Sul, Leste e } \\
\text { Norte) } \\
\text { Outubro/2004 } \\
\text { (EIA do } \\
\text { Trecho Sul) }\end{array}$ & Maio/2009 & Setembro/2010 \\
\hline $\begin{array}{l}\text { Emissão da } \\
\text { Licença } \\
\text { Prévia }\end{array}$ & Dezembro/1997 & Fevereiro/2006 & Abril/2010 & Julho/2011 \\
\hline $\begin{array}{l}\text { Número de } \\
\text { audiências } \\
\text { públicas }\end{array}$ & 3 & 9 & 6 & 4 \\
\hline \multicolumn{5}{|c|}{$\begin{array}{r}\text { Legenda: -: Não realizado. *: Documento fez parte do processo, mas não constava nos volumes } \\
\text { acessados. Os volumes disponibilizados dos trechos Sul, Leste e Norte iniciam após apresentação } \\
\text { do EIA/RIMA }\end{array}$} \\
\hline
\end{tabular}

Fonte: Elaborado pela autora.

\subsubsection{Trecho Oeste}

Em fevereiro de 1997, foi criado um grupo de trabalho intergovernamental composto por representantes do ministério de transportes, do governo do estado de São Paulo e da prefeitura municipal de São Paulo para definir diretrizes da obra, propor formas de financiamento, 
definir atribuições e estabelecer cronograma para a obra do Rodoanel. Este grupo poderia convocar técnicos para aprofundamento das propostas.

Após este grupo de trabalho definir as questões relacionadas ao empreendimento, foi dado início ao processo de Licenciamento Ambiental do Rodoanel em 11 abril de 1997 quando foi apresentado o Relatório Ambiental Preliminar (RAP) do primeiro trecho do Rodoanel, com o nome de Trecho Oeste. Este trecho interligaria seis rodovias e um eixo ferroviário: rodovia dos Bandeirantes, Anhanguera, Castello Branco, Raposo Tavares, Regis Bittencourt, estrada velha de campinas e linhas da Ferrovia Paulista S/A (FEPASA) a oeste. Nos documentos não foi apresentada uma explicação clara da mudança de Trecho 1 para Trecho Oeste e não apresentou o projeto do Rodoanel na totalidade antes de colocar enfoque para o Trecho Oeste. Foi subentendido que, de alguma forma, o projeto do Rodoanel foi modificado de Trecho 1, 2 e 3 em sua concepção inicial para Trecho Oeste, Sul, Leste e Norte, formato em que o conhecemos atualmente, pois não foi possível compreender em que momento aconteceu essa mudança durante a realização das entrevistas.

Após a análise do RAP pelo Departamento de Avaliação de Impacto Ambiental da CETESB (DAIA), o mesmo solicitou que fosse realizado um EIA/RIMA. Logo em seguida, o DERSA em conjunto com a EMPLASA, STM e Secretaria dos Transportes protocolou um plano de trabalho para definição do Termo de Referência (TR) do EIA/RIMA do Rodoanel sem a solicitação do órgão ambiental, por este motivo foi solicitado a retirada do plano por estar sobrepondo etapas. Assim, no dia 20/05/1997, é protocolado novamente o plano de trabalho. Em seguida, a Câmara Técnica de Sistemas de Transportes do Conselho Estadual do Meio Ambiente (CONSEMA) iniciou a análise deste plano, realizando três reuniões para discussão e solicitando audiência pública para análise do plano de trabalho.

O segundo momento participativo identificado no processo referente ao Trecho Oeste do Rodoanel foi o registro da Audiência Pública sobre o RAP, realizada no dia 3 de julho de 1997. Apesar de o título da audiência indicar que a mesma tinha como objeto o RAP, os documentos do processo levaram a crer que esta mesma audiência foi considerada no parecer técnico do DAIA como audiência sobre a análise do Plano de Trabalho para elaboração do TR, causando uma certa confusão no entendimento. Nesta parte do processo, foi possível observar uma desordem cronológica dos documentos e que o volume de informações disponíveis era escasso, o que dificultou o entendimento dos fatos e criou a sensação de que o processo aconteceu de forma apressada, o que, por outro lado, também pode ter ocorrido.

O TR foi definido em julho de 1997 e já em setembro de 1997, o empreendedor apresentou o EIA/RIMA do Trecho Oeste do Rodoanel, elaborado pela FESPSP. Durante a 
etapa de análise do estudo pelo órgão ambiental, foram realizadas duas audiências públicas sobre o EIA/RIMA nos dias 13 e 18 de novembro de 1997 nas cidades de Osasco-SP e São Paulo-SP, respectivamente. As duas cidades escolhidas foram as maiores afetadas pelo projeto e os outros quatro municípios que seriam afetados pelo Rodoanel não tiveram nenhuma audiência pública (ALONSO; COSTA, 2004).

Foi possível observar no processo do Trecho Oeste do Rodoanel dois momentos principais em que a participação aconteceu, sendo o primeiro na fase de elaboração do TR por meio da realização de uma audiência pública e o segundo na fase de análise do EIA/RIMA também com a realização de duas audiências públicas. Além destes momentos, foi possível identificar o envolvimento do CONSEMA no processo como outra forma de participação. Não estavam documentadas evidências de publicações em jornais para dar publicidade à abertura do processo, audiências públicas, EIA/RIMA e emissão da LP. Um dos motivos de o processo do Trecho Oeste do Rodoanel ser mais escasso em evidências de participação em comparação com os outros trechos foi levantado por um dos entrevistados:

Antigamente o ordenamento jurídico era diferente. Para se fazer uma audiência pública em SP era necessário que certos extratos sociais, como ONGs, partidos políticos, o MP, pedissem a audiência pública. Caso alguém daqueles extratos que tinham direito de pedir, pedisse, e a audiência pública não fosse feita, isso poderia inclusive invalidar a licença eventualmente concedida. Depois de um certo tempo, nós ultrapassamos essa modalidade de pedidos, ficando já antecipadamente determinado que todas as obras que são capazes de produzir significativo impacto ambiental, a CETESB é obrigada a pedir audiência pública. Portanto, nesses casos é necessária a oitiva da sociedade (Entrevistado A1).

Na época em que o licenciamento aconteceu, o processo estava amparado pela Resolução n CONAMA 01/1986, Resolução CONAMA n 9/1987 e pela Resolução SMA n 42/1994. Estas normas previam a possibilidade de consulta do EIA/RIMA e o recebimento de comentários por interessados, mas a realização de audiências públicas era o principal instrumento de participação utilizado para envolver o público. Alonso e Costa (2004) analisaram a dinâmica das audiências públicas no caso do Rodoanel e identificaram que, no caso do Trecho Oeste, um total de 920 pessoas participaram das três audiências realizadas, um número muito limitado considerando a quantidade de cidadãos a serem afetados pelo projeto.

Considerando que a legislação sobre Licenciamento Ambiental e AIA era muito recente em 1997, o entrevistado C3 apontou o seguinte:

Ainda existia uma cultura muito forte na engenharia de fazer as coisas pelo custo benefício e uma tradição governamental de fazer o que queriam sem saber muito bem das consequências. Durante o licenciamento ambiental do 
Trecho Oeste, talvez os envolvidos nem soubessem como fazer um EIA/RIMA e nem o que exigir, resultando em uma falta de informações e noção do que deveria ser seguido, foi uma fase completamente diferente das outras. $\mathrm{O}$ fato é que depois disso vieram denúncias e judicialização, levando a uma evolução do processo e da participação no caso do Rodoanel (Entrevistado C3).

Após a realização das audiências públicas, o EIA/RIMA foi analisado pelo DAIA e aprovado pelo CONSEMA, levando a emissão da Licença Prévia (LP) em dezembro de 1997.

Em dezembro do ano de 2000, a PROTRAN Engenharia, contratada pela DERSA, protocola um documento referente ao plano de trabalho para o EIA/RIMA do Rodoanel contemplando os Trechos Sul, Leste e Norte. Neste momento, é apresentado um mapa do empreendimento em sua totalidade (Figura 14).

Na Figura 14, o segmento na cor vermelha corresponde ao Trecho Norte do Rodoanel, o segmento na cor azul clara o Trecho Leste, o azul escuro o Trecho Sul e o amarelo representa o Trecho Oeste. Em 2002, a DERSA apresentou o EIA/RIMA para os três trechos remanescentes. De acordo com o Entrevistado B1, ao apresentar este estudo em audiência pública, foram recebidas diversas reclamações de prefeituras, ONGs e Ministério Público (MP) especialmente sobre o Trecho Sul e Norte. Sánchez e Silva-Sánchez (2008) apontam que durante a análise do estudo pelo DAIA, foram coletadas provas para declará-lo como insuficiente e, diante disso, o DERSA retirou o estudo antes de a análise ser finalizada, levando a suspensão do processo. Desta forma, o DERSA decidiu responder às questões de abrangência metropolitana e a Avaliação Ambiental Estratégica (AAE) foi vista como uma alternativa e a empresa FESPSP foi responsável por elaborá-la. A AAE é uma ferramenta que tem como objetivo avaliar os potenciais impactos das políticas, planos e programas propostos sobre os recursos naturais, as condições sociais, culturais e econômicas (IAIA, 2020), de modo a promover um padrão de desenvolvimento mais sustentável (FUNDINGSLAND TETLOW; HANUSCH, 2012).

Não há requisitos formais para AAE no estado de São Paulo e nem no Brasil, entretanto, no caso do Rodoanel, o DERSA enxergou a AAE como um caminho possível para facilitar a aprovação do projeto por meio do tiering (SÁNCHEZ; SILVA-SÁNCHEZ, 2008). O conceito de tiering pode ser entendido como a elaboração de avaliações ambientais consecutivas em diferentes níveis de planejamento (políticas, planos, programas e projetos) que influenciam umas às outras (ARTS; TOMLINSON; VOOGD, 2012). 


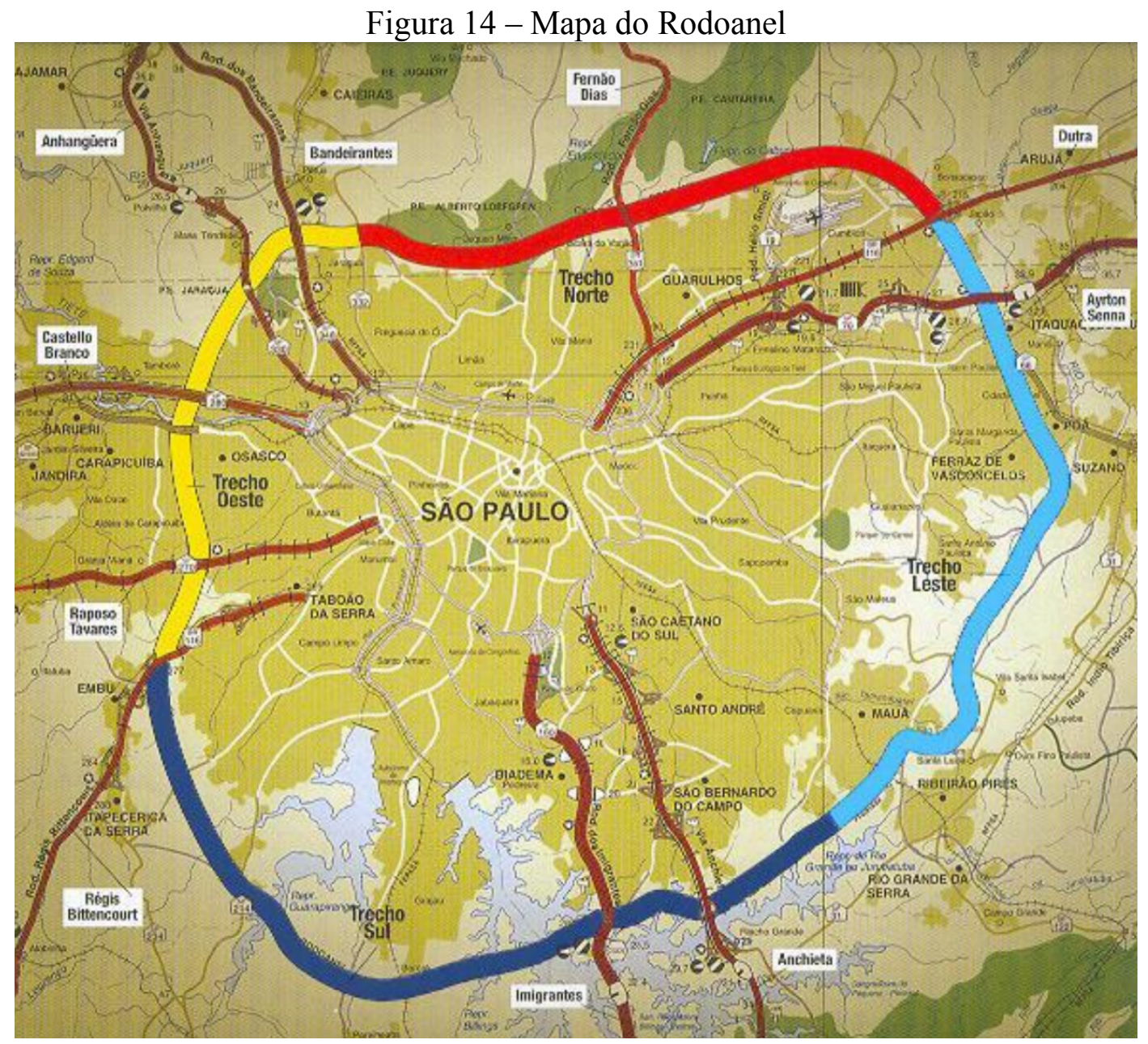

Fonte: DERSA, 2000.

De acordo com o Entrevistado B1, a AAE tinha como objetivo estudar quais eram as principais questões a serem analisadas, quais as vantagens e desvantagens do projeto para região metropolitana do ponto de vista socioambiental, e verificar se o traçado de um trecho iria inviabilizar a implantação do trecho seguinte. Ele ainda apontou o seguinte:

Após a AAE se seguiria para o licenciamento ambiental efetivo e detalhamento do projeto por trechos, licenciando por trechos. O ideal pela norma é que o empreendimento seja licenciado como um todo, mas no caso do Rodoanel que é um megaempreendimento, se você fizesse um EIA total, licenciasse o todo, um trecho seria implantando agora e o trecho seguinte apenas 15 anos depois devido à complexidade e demora. Isso seria inviável, pois as condições sociais, ambientais e urbanas seriam diferentes depois de tanto tempo. A AAE mostrou que não haveria prejuízos ambientais em se licenciar por trechos. Houve um amplo debate e foi uma experiência muito boa, pois, o empreendedor tomou a responsabilidade de debater com muitos interlocutores discutindo com os vários interessados no projeto (arquitetos, conselhos, comitês de bacias, ONGs, universidades, etc.), mas ainda assim houve vários questionamentos (ENTREVISTADO B1).

O relatório da AAE afirma que as expectativas do público foram levadas em consideração, no entanto, a $\mathrm{AAE}$ foi solicitada como um relatório técnico sem previsão de 
contribuição pública e a sociedade contribuiu com suas opiniões em oportunidades anteriores a AAE (SÁNCHEZ; SILVA-SÁNCHEZ, 2008).

Como não existia dispositivos legais para orientar a AAE e a aplicação dos seus resultados, o relatório final foi arquivado no processo, revisado pelo DAIA e aprovado pelo Conselho Estadual de Meio Ambiente (CONSEMA) em setembro de 2004 como se fosse um EIA/RIMA e, após, foi dado seguimento ao licenciamento ambiental de cada um dos trechos de forma individual (SÁNCHEZ; SILVA-SÁNCHEZ, 2008).

Como a AAE e a participação envolvida na sua realização não era o foco desta pesquisa, a sua descrição foi realizada apenas para entender o desenrolar do processo de Licenciamento Ambiental e em que contexto ela foi aplicada.

\subsubsection{Trecho Sul}

O segundo trecho a iniciar o processo de Licenciamento foi o Sul, no ano de 2004, e, após o protocolo do EIA/RIMA, foram realizadas oito audiências públicas. A primeira delas foi realizada em São Paulo-SP no bairro da Liberdade no dia 25/11/2004; a segunda em Santo André-SP no dia 30/11/2004; a terceira em Embu no dia 02/12/2004; e a última do ano no dia 21/12/2004 no bairro de Santo Amaro em São Paulo-SP. No ano de 2005, foram realizadas mais quatro audiências públicas, no dia 13/03/2005 novamente no bairro da Liberdade em São Paulo; no dia 06/10/2005 em São Bernardo do Campo; e no bairro de Santo Amaro em São Paulo nos dias 10/10/2005 e 21/12/2005.

O primeiro documento presente no processo dos volumes disponibilizados e analisados é de dezembro de 2004 e já representa uma forma de participação, referindo-se a um abaixoassinado contra o traçado do Rodoanel apresentado nas audiências públicas anteriores solicitando que ele fosse revisto em respeito às comunidades e ao patrimônio ambiental envolvido.

Ao longo do ano de 2005, iniciou-se uma sequência de: manifestações da sociedade civil, ONGs, associações de bairro, comitê de bacias e institutos direcionadas ao DAIA, indicando falhas no processo de licenciamento, indução à ocupação de mananciais, solicitações de cópia dos estudos desenvolvidos sobre o Trecho Sul do Rodoanel; publicações de mesas de debates e audiências públicas sobre o tema, organizadas pelas prefeituras municipais envolvidas no processo; manifestações técnicas e solicitações de detalhamento de medidas elaboradas por instituições públicas como, por exemplo, Instituto Florestal (IF), Instituo de Pesquisas Tecnológicas (IPT), Instituto Biológico (IB) e comitê de bacias; e pareceres técnicos 
elaborados pelo Ministério Público do Estado de São Paulo (MPSP) e pelas prefeituras de todos os municípios envolvidos.

Denúncias sobre desmatamento ilegal em áreas de mananciais realizados por funcionários da empresa DERSA também apareceram, seguidas da emissão de autos de infração ambiental emitidos pelo órgão ambiental. Foram identificadas também diversas solicitações de esclarecimentos realizadas por associações de moradores. A maioria das manifestações foi contrárias a implantação do empreendimento, no entanto, também foram identificadas manifestações favoráveis ao Rodoanel, embasadas na justificativa de melhorar a fluidez no trânsito na cidade de São Paulo, a melhoria da poluição sonora e do ar e do estresse da população, melhoria na integração metropolitana, maior segurança para transporte de cargas perigosas pelo Rodoanel, aumento da atividade econômica e redução do tempo de viagem por passageiros na RMSP. Foram poucos documentos adotando essa postura de defesa do empreendimento e todas foram emitidas por associações relacionadas à indústria, ao transporte de cargas ou à logística. No caso de o argumento dos transportes de cargas perigosas ser mais seguro ao ser realizado pelo Rodoanel, se contrapõem com outras manifestações que questionam as consequências dos potenciais acidentes com essas cargas em áreas de mananciais já fragilizadas na região do Trecho Sul do Rodoanel.

Um estudo realizado pelo Laboratório de Habitação e Assentamentos Humanos (LABHAB) da Faculdade de Arquitetura e Urbanismo (FAU) da Universidade de São Paulo (USP), por solicitação do MP, foi protocolado em julho de 2005 no processo e tinha como objetivo subsidiar as decisões acerca da implementação do Trecho Sul do Rodoanel. Este estudo foi intitulado como "Estudo preliminar: impactos urbanísticos do Trecho Oeste do Rodoanel Mário Covas". No que concerne à solicitação do MP, era solicitado um parecer do LABHAB acerca de uma fórmula utilizada por Biderman (2005) para tentar estimar o impacto da implementação do Rodoanel Sul sobre a localização das empresas e sobre o número de domicílios por classe de renda e por zonas de origem-destino. O parecer solicitado resultou no estudo realizado pelo laboratório da FAU/USP, que além de questionar o artigo que utilizou a fórmula matemática também analisou os eventuais impactos urbanos gerados pelo Trecho Oeste do Rodoanel com foco em uma possível contribuição para indução da expansão urbana periférica (LABHAB, 2005). De acordo com o Entrevistado D1:

O objetivo do estudo era entender como eram os impactos urbanísticos do Trecho Oeste e fazer uma transferência/projeção do que aconteceu nele para o Trecho Sul, considerando que a região oeste tinha uma capacidade de absorver o impacto do rodoanel completamente diferente da região sul que eles iriam construir. O impacto seria muito maior, pois o Trecho sul é uma região de fragilidade ambiental incomparavelmente maior ao Trecho oeste, 
este que, em contrapartida é de uma área da cidade que tem um potencial aceitável de adensamento e crescimento da região metropolitana (Entrevistado D1).

Neste estudo sobre os impactos urbanísticos, foram contemplados questionamento acerca da expansão da ocupação e sua relação com o projeto de uma rodovia classe zero, que tinha como proposta não realizar nenhum acesso em sua extensão. Também foi questionada a justificativa sobre o transporte de cargas e sobre a logística de transportes intermodais e foram apresentadas as dinâmicas que afetam os processos de expansão urbana, como a valorização imobiliária, uso e ocupação do solo e a mitigação dos impactos negativos do Rodoanel (LABHAB, 2005). Devido à repercussão do tema sobre a problemática da expansão urbana nas áreas de mananciais próximas ao empreendimento do Rodoanel, a EMPLASA elaborou um parecer técnico dizendo que a urbanização não teria sua dinâmica atrelada a construção do Trecho Sul.

Algumas manifestações denunciavam o passivo ambiental deixado pela obra do Trecho Oeste do Rodoanel como, por exemplo: os problemas de ruído acima do permitido pela OMS que afetaram a qualidade de vida da população do entorno; a poluição do ar que agravou quadros de doenças respiratórias alérgicas; a falta do plantio de árvores para minimizar as complicações citadas anteriormente; e desvalorização imobiliária, rachaduras em imóveis e outros abalos na infraestrutura próxima. Uma das manifestações apontava a falta de acompanhamento após a implantação de um empreendimento e a falha na articulação intersetorial, trazendo à luz os efeitos da implantação do Trecho Oeste e todos os débitos compensatórios e mitigatórios não cumpridos que haviam sido definidos no processo de licenciamento ambiental. Por conta disso, o manifesto solicitava que aprimorassem a fase de acompanhamento e monitoramento do processo, estabelecendo um cenário de coresponsabilidades e controle técnico/social por meio da criação de um conselho gestor do Rodoanel contemplando todos os atores envolvidos. Desta forma, estariam garantidos o exercício do poder local e do terceiro setor e o acompanhamento da implantação do empreendimento. Em outras manifestações também foram denunciadas a falta de execução das medidas mitigadoras e compensatórias dos impactos ambientais provocados pela construção do Trecho Oeste. Este é outro ponto que remete à problemática da falta de acompanhamento e monitoramento do processo de AIA no estado de São Paulo.

Sobre a publicidade do processo, foram identificadas diversas publicações em jornais, rádios e panfletos sobre a realização de audiências públicas, já sobre a disponibilização do EIA/RIMA, foram identificadas publicações de divulgação para realização de consulta pública no site do DERSA e presencialmente em diversos locais como a biblioteca do 
DERSA, do Departamento de Estadas de Rodagem (DER), da assembleia legislativa do estado de São Paulo, em um ponto na Estação da Sé do metrô, estação Barra Funda da Companhia Paulista de Trens Metropolitanos (CPTM), Poupatempo de São Bernardo do Campo e no Centro de Informações do Rodoanel (CIR), uma central criada para atender as demandas do público interessado no processo. De acordo com o Entrevistado A2, o Rodoanel era uma obra com porte tão significativo que mereceu uma ouvidoria exclusiva para atendimento às considerações e solicitações específicas do caso.

Houve reclamações sobre o tempo disponibilizado para a população falar nas audiências públicas, alegando não ter sido suficiente e que os responsáveis pela obra adotavam posições de imposição do empreendimento. Também houve denúncias sobre o não cumprimento do prazo para divulgação das audiências públicas após publicação em jornal de grande circulação e no diário oficial, incluindo a realização de um abaixo-assinado pedindo o cancelamento das audiências públicas realizadas nos dias 6 e 10 de outubro de 2005 pela divulgação inadequada e falta de Relatórios conclusivos solicitados pelo Ministério Público Federal (MPF) e IBAMA.

Uma das principais polêmicas sobre o Trecho Sul do Rodoanel iniciou com o protocolo de uma declaração realizada por lideranças indígenas Guarani das Terras Indígenas Barragem, Tenondé Porã, Krukutu e Jaraguá, localizadas no município de São Paulo. Eles manifestaram sua preocupação com o projeto do Trecho Sul afetarem suas atividades cotidianas e solicitaram estudos com a participação deles na forma de um levantamento etnoambiental Guarani, conforme exigência da FUNAI. Em resposta, o DERSA justificou que o EIA/RIMA do Trecho Sul ofereceu esclarecimentos sobre as interferências do Rodoanel nas comunidades indígenas utilizando um estudo antropológico de 2002 sobre as culturas Guaranis instalados na Serra do Mar e um estudo de 2000 sobre os impactos de outro empreendimento de transmissão de eletricidade da companhia Furnas Centrais Elétricas S.A., subentendendo que, desde que estes documentos foram produzidos, as variáveis físicas e demográficas que os embasaram não sofreram alterações. Logo, eles poderiam ser aproveitados considerando que o traçado estaria a oito quilômetros de distância das comunidades, não causando interferência em suas áreas.

De acordo com o Entrevistado C3, isso culminou em uma ação do MP em 2005, solicitando que o IBAMA participasse ativamente da condução do licenciamento ambiental dos Trechos Sul, Leste e Norte do Rodoanel, lidando com todos os assuntos relacionados a três aspectos: comunidades indígenas, reserva da biosfera e mata atlântica. Sobre a atuação do IBAMA no processo, foram levantados os seguintes pontos: 
Para os assuntos indígenas, o IBAMA convocou a FUNAI que enviou uma funcionária que conhecia a cultura Guarani. Também foram identificadas outras comunidades na Represa Billings além da comunidade do Jaraguá. Baseado nesse trabalho, o IBAMA com a FUNAI elaboraram um parecer técnico. Sobre a reserva da biosfera, o IBAMA convocou uma reunião com o órgão colegiado da reserva da biosfera do cinturão verde da cidade de São Paulo. Nessa oportunidade, eles elaboraram um parecer sobre o rodoanel Sul. O parecer deles foi bem amplo e realizado em parceria com ONGs, com uma percepção bem abrangente que auxiliou a expandir a visão sobre diversos aspectos. Com relação à mata atlântica, os técnicos do IBAMA que tinham bastante experiência em fauna e flora elaboraram o parecer técnico específico. Tínhamos discussões bastante produtivas com os técnicos do governo do estado e com a DERSA. Assim saiu o Trecho sul. No Trecho Sul, no início, quando era encontrada alguma irregularidade o estado era comunicado e, se após um mês ou dois, não regularizassem, o próprio IBAMA emitia uma multa. Foi boa a participação do IBAMA nesse ponto e ajudou o pessoal a se nortear e a se corrigir (ENTREVISTADO C3).

Após o envolvimento do IBAMA, a FUNAI emite um termo de referência e solicita a realização dos estudos etnoecológicos, posteriormente realizado pela empresa de consultoria CONSPLAN. Um mês depois, uma representante do Centro de Trabalho Indigenista (CTI) protocola uma manifestação de que o estudo etnoecológico desenvolvido pela CONSPLAN havia sido plagiado de um trabalho de sua autoria publicado em livro e disponibilizado no site do CTI e que o estudo também havia incluído cópia de depoimentos integrais de lideranças indígenas coletados em entrevistas, se apropriando destes conteúdos sem qualquer autorização ou referência. Após a polêmica, a FUNAI solicita audiência pública na terra indígena Guarani, garantindo o exercício dos direitos civis e políticos dos povos indígenas estabelecidos pelo Estatuto do Índio (Lei Federal n 6001/1973 e Convenção OIT 169/1989). Após essa solicitação, houve um mandado de intimação emitido pela justiça federal para a Secretaria do Meio Ambiente, resultante de uma ação civil pública com pedido de anulação do parecer concedido pela FUNAI que dispensava a conclusão do estudo etnoambiental nos moldes do termo de referência para concessão da LP e solicitando o adiamento da audiência pública até a conclusão deste estudo.

A comunidade do Jaraguá, localizada nas imediações do Trecho Oeste do Rodoanel, não havia sido identificada durante o processo de licenciamento/AIA daquele trecho. Logo, como já estava em operação, havia uma pendência com relação aos estudos etnoecológico nas comunidades indígenas do Jaraguá. A DERSA solicitou que a elaboração deste estudo estaria vinculada à concessão da LI do Trecho Sul e, por conta de os dois trechos terem sido licenciados em momentos diferentes, o IBAMA concordou que o estudo etnoecológico das comunidades indígenas do Jaraguá constasse como uma das exigências que integrariam a LP do Trecho Sul e que deveria ser entregue antes da LI do mesmo. Em novembro de 2005, foi 
protocolada a nova versão do estudo etnoecológico pela CONSPLAN. Este foi o principal entrave jurídico para dar seguimento ao processo, e desde que regularizado, foi realizada uma última audiência pública do processo em 21/01/2006. Logo, o CONSEMA aprovou o EIA/RIMA do Trecho Sul do Rodoanel em fevereiro de 2006 e a LP foi emitida do mesmo mês.

\subsubsection{Trecho Leste}

Em 2009, é iniciado o licenciamento ambiental do Trecho Leste do Rodoanel. Após o protocolo do EIA/RIMA realizado pela FESPSP, o DAIA solicita a realização de sete audiências públicas, sendo uma em cada município afetado pelo empreendimento, sendo a primeira no município de Mauá em 02/06/2009, seguida de Ribeirão Pires em 09/06/2009, Suzano em 18/06/2009, Poá em 14/07/2009, Itaquaquecetuba em 16/07/2009, em Arujá em 23/07/2009 e no bairro da Liberdade em São Paulo em 28/07/2009. Foram identificados inúmeros registros de publicidade do estudo para consulta e das audiências públicas em todos os municípios afetados via rádio e jornais.

Após as audiências, foram recebidas também diversas manifestações por escrito solicitando esclarecimentos de moradores da região, associações de bairro, ONGs, sindicatos, institutos, partidos políticos, protocolo de abaixo-assinado, solicitações de cópias do estudo pelo MPSP e outras entidades, pareceres técnicos elaborados pela Fundação Florestal (FF), IBAMA, Instituto do Patrimônio Histórico e Artístico Nacional (IPHAN), órgãos municipais e das prefeituras dos municípios envolvidos com recomendações ao projeto. No entanto, o volume de manifestações por escrito dessas entidades foi menor quando comparado com o Trecho Sul.

Algumas das temáticas que foram questionadas diziam respeito aos riscos de indução da expansão urbana, preocupações com relação às desapropriações, fragmentação de áreas verdes, falta de discussão de alternativas para o traçado, preocupação com áreas de mananciais. Também apareceram denúncias de irregularidades nas obras do Trecho Oeste e Sul, da depreciação dos imóveis e da situação de abandono da população afetada pelo Rodoanel no município de Santo André. Além das problemáticas, também apareceram manifestações em defesa do Rodoanel escritas por moradores que passaram pelo processo de reassentamento do Trecho Oeste, que encararam a mudança como positiva, pois ganharam uma moradia estruturada com escritura que não tinham antes do projeto do Rodoanel e passaram a morar em um local com estrutura de lazer e iluminação pública, o que melhorou 
a qualidade de vida dos reassentados. Manifestações em favor do empreendimento vieram de associações de empresas e indústrias da região.

Dentre as principais polêmicas levantadas, estava a solicitação para ampliar e qualificar o debate com as comunidades afetadas no licenciamento do Trecho Leste, baixa qualidade do RIMA, o qual não cumpria com seu principal objetivo de ser compreendido por cidadãos comuns, apresentava dados copiados dos RIMAs dos Trechos Oeste e Sul e que refletiam uma pesquisa feita em bibliotecas e sites de busca, sendo incompatíveis com a realidade da região a ser afetada pelo Trecho Leste.

Também houve reclamações sobre o tempo para análise de todo o volume do EIA/RIMA, apontando não ser suficiente dado o intervalo entre o dia em que o estudo foi disponibilizado e a data agendada para audiência. Além disso, após às seis audiências públicas realizadas, foi solicitada a realização de novas audiências para que houvesse melhor compreensão dos impactos da obra por parte da comunidade afetada que ainda permanecia confusa. Ainda que tivessem solicitado a realização de mais audiências, em nota técnica emitida pela CETESB para o CONSEMA, foi apontado que o DAIA acompanhou as que haviam sido realizadas nos sete municípios e que estas contaram com ampla participação da sociedade civil, incluindo representantes de secretariados municipais, câmaras municipais, promotorias de justiça e meio ambiente e moradores do município, concluindo, então, que as audiências: "cumpriram com seus objetivos, permitiram a manifestação da comunidade interessada e garantiram o direito democrático da população manifestar-se não ficou prejudicado" (CETESB, 2009).

Em fevereiro de 2010, a CETESB emitiu parecer técnico sobre o EIA/RIMA; em março, o CONSEMA aprovou a viabilidade ambiental do empreendimento; e, em abril de 2010, foi emitida a LP do Trecho Leste do Rodoanel.

Durante a análise de conteúdo do processo do Trecho Leste foi possível observar que estava mais fácil de compreender a ordem cronológica dos fatos pois as evidências estavam registradas de forma clara.

\subsubsection{Trecho Norte}

No mês de setembro de 2010, o DERSA protocolou apresentou o EIA/RIMA do Trecho Norte. Enquanto o estudo estava sob análise do órgão ambiental, foram realizadas quatro audiências públicas: no dia 07/10/2010 no município de Arujá, nos dias 15/12/2010 e 19/01/2011 em Guarulhos e no dia 16/12/20 no bairro da Liberdade em São Paulo-SP. 
Após dar publicidade ao início do processo, já foi identificado o protocolo de uma manifestação de um conselho comunitário de moradores e outras entidades antes mesmo de realizar a primeira audiência pública. Neste documento, era solicitado que a construção do Trecho Norte fosse vetada, pois seu traçado prejudicaria o Parque Estadual da Cantareira e que a Rodovia Dom Pedro I cumpriria por si só o papel de conectar os Trechos Oeste e Leste. Também foram registradas duas solicitações pela prefeitura de Guarulhos para que a primeira audiência pública no município fosse adiada por conta do curto período de tempo para análise do EIA/RIMA devido a sua complexidade. Em resposta, o CONSEMA adiou uma vez a audiência do dia 9/12 para o dia 15/12/2010 e o DERSA emitiu uma carta negando o segundo adiamento com a justificativa a seguir:

As audiências públicas do CONSEMA não têm caráter deliberativo e que seu objetivo é ouvir as dúvidas da população e da sociedade em geral. As dúvidas levantadas em audiências têm que ser esclarecidas pelo empreendedor e o adiamento prestará um desserviço à análise de tão complexo empreendimento, se prestando na perda de oportunidade para livre manifestação da população do município de Guarulhos (DERSA 2010).

A partir das realizações das audiências públicas, foram recebidas solicitações do MPSP solicitando o envio do EIA/RIMA, reclamando da falha na comunicação acerca das audiências e do curto tempo que impossibilitaria a leitura da proposta e análise do setor técnico do ministério. O MPF também publicou recomendação de adiamento da audiência pública para um período posterior às festas de final de ano, levando em consideração um abaixo assinado realizado pelos moradores, erros no EIA/RIMA e a falta de destaque da realização das audiências no site da Secretaria do Meio Ambiente, dificultando o acesso à informação. A última audiência pública foi, então, realizada em janeiro de 2011 e também vieram mais manifestações questionando a qualidade das informações do EIA/RIMA e solicitando a realização de mais audiências para mais esclarecimentos.

Foram registrados pareceres técnicos das prefeituras de todos os municípios afetados, de comitês de bacias, IF, FF, Conselho de Defesa do Patrimônio Histórico, Arqueológico, Artístico e Turístico do Estado (CONDEPHAAT); e manifestações de ONGs, advogados, associações de bairro, associações ambientais, associações comerciais, conselhos municipais, sindicatos, comitê de bacias hidrográficas. Todos registrando sua preocupação com a implantação do empreendimento, levando em consideração os impactos ao Parque Estadual da Cantareira, danos aos recursos hídricos da região, impactos na qualidade do ar, impactos na fauna, riscos de contaminação no solo por conta do tráfego de cargas perigosas, alterações urbanísticas, desvalorização imobiliária, nível de ruído, as desapropriações, alternativas de traçado e medidas compensatórias. Também foram identificados estudos e manifestações 
referentes aos patrimônios culturais e históricos na região afetada pelo Trecho Norte do Rodoanel, como capelas, vila histórica da Cantareira, comunidades agrícolas japonesas e patrimônio geológico e arqueológico. A participação de associações de bairros elaborou estudos técnicos sobre os impactos do empreendimento principalmente sobre o Parque Estadual da Cantareira que contaram com o apoio de diversas entidades e prefeituras que compartilhavam das mesmas preocupações com relação à preservação ambiental da região.

No processo constavam volumes com inúmeras páginas registrando diversos abaixoassinados contrários ao Trecho Norte do Rodoanel ou solicitando modificações no traçado, e também artigos de jornais foram protocolados documentando a ocorrência de manifestações e passeatas. Um diferencial do processo do Trecho Norte foi que diversos moradores dos municípios afetados enviaram e-mails individuais solicitando informações, manifestando suas preocupações e, na maioria das vezes, se posicionando contra a construção do empreendimento. Foi possível notar nestes e-mails o desconhecimento da população com relação ao licenciamento ambiental e ao seu rito processual e foram identificadas reclamações quanto ao número de audiências públicas realizadas (três) ser insuficiente e solicitações de espaços oficiais para uma discussão mais próxima com a população.

Com relação à publicidade, foram protocolados comprovantes de propaganda de todas as audiências públicas realizadas em jornais e rádios. No entanto houve manifestações levantando a dificuldade em acessar informações sobre o EIA/RIMA pela internet e dificuldade em se comunicar com os atendentes do órgão ambiental.

A CETESB emitiu seu parecer técnico em abril de 2011, o IBAMA emitiu o parecer sobre o Trecho Norte do Rodoanel em junho, o CONSEMA aprovou a viabilidade em no mesmo mês e a LP foi emitida em julho de 2011.

\subsubsection{Formas de participação do processo}

Após a análise das evidências de participação presentes no processo dos quatro trechos do Rodoanel, foi possível identificar os tipos de participação que ocorreram no processo de AIA deste empreendimento, e foram organizados na Tabela 14. 
Tabela 14 - Momentos de participação no processo de Licenciamento com AIA do estado de São Paulo, de acordo com os volumes analisados

\begin{tabular}{|c|c|c|c|c|}
\hline $\begin{array}{l}\text { Etapa do } \\
\text { processo }\end{array}$ & $\begin{array}{c}\text { Tipo de } \\
\text { participação }\end{array}$ & Descrição & $\begin{array}{c}\text { Nível de } \\
\text { participação }\end{array}$ & Trecho \\
\hline \multirow[b]{2}{*}{$\begin{array}{l}\text { Determinação } \\
\text { do escopo/TR }\end{array}$} & Publicidade & $\begin{array}{l}\text { Divulgação do plano de } \\
\text { trabalho para definição do } \\
\text { escopo/TR }\end{array}$ & $\begin{array}{l}\text { Participação } \\
\text { passiva }\end{array}$ & Oeste \\
\hline & $\begin{array}{l}\text { Reunião do } \\
\text { CONSEMA }\end{array}$ & $\begin{array}{c}\text { Fórum de discussão } \\
\text { deliberativa composto por } \\
\text { diversos segmentos } \\
\text { (governo, organizações da } \\
\text { sociedade, ambientalistas, } \\
\text { universidades, setor } \\
\text { produtivo e órgãos de } \\
\text { classe) para decidir sobre o } \\
\text { escopo do TR do EIA/RIMA }\end{array}$ & $\begin{array}{l}\text { Participação } \\
\text { interativa }\end{array}$ & Oeste \\
\hline \multirow{4}{*}{$\begin{array}{l}\text { Análise } \\
\text { técnica }\end{array}$} & Publicidade & $\begin{array}{l}\text { Divulgação do EIA/RIMA e } \\
\text { das datas e locais das } \\
\text { audiências públicas em } \\
\text { jornais e rádio; } \\
\text { e disponibilização do } \\
\text { EIA/RIMA para consulta em } \\
\text { plataformas online ou físicas }\end{array}$ & $\begin{array}{l}\text { Participação } \\
\text { passiva }\end{array}$ & $\begin{array}{l}\text { Sul, } \\
\text { Leste e } \\
\text { Norte }\end{array}$ \\
\hline & $\begin{array}{l}\text { Audiências } \\
\text { públicas }\end{array}$ & $\begin{array}{l}\text { Realização de audiências } \\
\text { públicas de caráter } \\
\text { consultivo que constituem } \\
\text { um momento formal para } \\
\text { apresentação do EIA/RIMA } \\
\text { e discussão do projeto com } \\
\text { os interessados }\end{array}$ & $\begin{array}{l}\text { Participação } \\
\text { através de } \\
\text { consulta }\end{array}$ & $\begin{array}{l}\text { Oeste, } \\
\text { Sul, } \\
\text { Leste e } \\
\text { Norte }\end{array}$ \\
\hline & $\begin{array}{l}\text { Consulta } \\
\text { pública }\end{array}$ & $\begin{array}{l}\text { Realização de workshops, } \\
\text { reuniões públicas }\end{array}$ & $\begin{array}{l}\text { Participação } \\
\text { através de } \\
\text { consulta }\end{array}$ & $\begin{array}{l}\text { Sul, } \\
\text { Leste e } \\
\text { Norte }\end{array}$ \\
\hline & $\begin{array}{l}\text { Manifestações } \\
\text { por escrito }\end{array}$ & $\begin{array}{l}\text { Abertura do prazo para } \\
\text { manifestações por escrito } \\
\text { dos interessados (ONGs, } \\
\text { associações, institutos, } \\
\text { prefeituras e sociedade civil) }\end{array}$ & $\begin{array}{l}\text { Participação } \\
\text { através de } \\
\text { consulta }\end{array}$ & $\begin{array}{l}\text { Sul, } \\
\text { Leste e } \\
\text { Norte }\end{array}$ \\
\hline \multirow[t]{2}{*}{ Decisão } & CONSEMA & $\begin{array}{c}\text { Fórum de discussão } \\
\text { deliberativa composto por } \\
\text { diversos segmentos } \\
\text { (governo, organizações da } \\
\text { sociedade, ambientalistas, } \\
\text { universidades, setor } \\
\text { produtivo e órgãos de } \\
\text { classe) para decidir sobre a } \\
\text { viabilidade ambiental do } \\
\text { empreendimento }\end{array}$ & $\begin{array}{l}\text { Participação } \\
\text { interativa }\end{array}$ & $\begin{array}{l}\text { Oeste, } \\
\text { Sul, } \\
\text { Leste e } \\
\text { Norte }\end{array}$ \\
\hline & Publicidade & $\begin{array}{c}\text { Publicidade do parecer } \\
\text { técnico, da manifestação do } \\
\text { CONSEMA e da emissão da } \\
\text { LP }\end{array}$ & $\begin{array}{l}\text { Participação } \\
\text { passiva }\end{array}$ & $\begin{array}{l}\text { Oeste, } \\
\text { Sul, } \\
\text { Leste e } \\
\text { Norte }\end{array}$ \\
\hline
\end{tabular}

Fonte: Elaborado pela autora. Baseado em André et al. (2006) e Faria (2017). 
As etapas de apresentação da proposta, triagem, elaboração do EIA/RIMA e acompanhamento não foram contempladas na Tabela 14 devido ao recorte definido nos volumes dos processos analisados, pois foram disponibilizados apenas os documentos após a elaboração do EIA/RIMA até a decisão sobre a emissão da LP.

A publicidade do TR e a reunião do CONSEMA realizada na fase de definição do escopo do EIA/RIMA foi identificada apenas no Trecho Oeste. Com relação a estes momentos, apesar de previstos na Resolução SMA n 49/2004 e n 54/2004, não foi possível identificálos nos trechos Sul, Leste e Norte pois os processos destes trechos disponibilizados pelo órgão ambiental só contemplaram os documentos após a publicação em jornal sobre o protocolo do EIA/RIMA. A ausência de registros destes momentos participativos nos trechos Sul, Leste e Norte não significa que não ocorreram.

No Trecho Oeste não foi possível identificar evidências da publicidade dada aos estudos, à divulgação das audiências públicas e a abertura do período de manifestações dos interessados sobre o empreendimento, bem como o registro de quanto tempo e onde o EIA/RIMA esteve sob consulta do público durante o processo de AIA. As manifestações por escrito dos interessados também não foram identificadas neste trecho. A ausência do registro destes momentos participativos nos documentos disponibilizados para análise não significa que não ocorreram, mas que não foram devidamente documentados e arquivados ou que estavam registrados em volumes seguintes a emissão da LP ou em volumes não disponibilizados pelo órgão ambiental.

Contrastando os momentos de participação apresentados na Tabela 14 com os princípios internacionais de boas práticas da participação pública na AIA (ANDRÉ et al., 2006), podese destacar alguns indícios de que a participação no estudo de caso foi parcialmente: adaptada ao contexto, informativa e proativa, adaptável e comunicativa, cooperativa e imputável. A participação pode ser considerada parcialmente adaptada ao contexto, pois foi possível identificar que o envolvimento das instituições sociais e o respeito aos valores das comunidades do entorno do empreendimento foram considerados durante o processo de AIA e nos momentos em que esse envolvimento não ocorreu, a própria comunidade e instituições demandaram por reconhecimento. A participação também foi informativa e proativa no sentido de que foi possível identificar evidências no processo de que o público foi informado através de diversos canais de comunicação. Com relação à proatividade, o público é que buscou mais formas de se envolver no processo, indo além do que lhes era garantido pela legislação vigente. A participação foi adaptável e comunicativa sob o olhar do cumprimento das exigências previstas em legislação e por conta da localização e número de audiências 
públicas realizadas, que consideraram a realidade e demandas de cada trecho do empreendimento. Porém, não foi verificada a adaptabilidade da linguagem utilizada para os diferentes públicos e não foi analisada a efetividade dessa comunicação nos momentos participativos do processo. A participação no caso estudado pode ser considerada parcialmente cooperativa, pois buscou-se considerar as manifestações recebidas pelas partes interessadas na tentativa de estabelecer um consenso e aceitação da proposta. A participação também pode ser considerada imputável em partes, pois foram identificadas evidências das contribuições do público no processo de AIA e que possivelmente foram consideradas para melhorar o projeto, no entanto, não foram analisadas as respostas do empreendedor às solicitações do público e do órgão ambiental aos interessados.

É exceção o Trecho Oeste, já que as informações analisadas não levaram a nenhum indício de boas práticas. Destaque maior tem a presença da boa prática da participação ser educativa, já que foi evidente que as partes interessadas demonstraram maior envolvimento nos processos no decorrer do tempo, reivindicando seus direitos. Contudo, a educação não foi um objetivo do órgão ambiental e do empreendedor, e sim adquirida, de forma que o papel das partes interessadas passou a ser melhor compreendido e respeitado no decorrer do processo de AIA de cada um dos trechos. Por outro lado, a participação parece não ter sido inclusiva e equitativa devido à falta de envolvimento das comunidades indígenas no Trecho Oeste e Sul. No entanto, após a pressão popular realizada durante o processo do Trecho Sul, as demandas destas comunidades foram consideradas e seu envolvimento realizado.

O envolvimento do público interessado em um determinado empreendimento faz parte do processo de AIA. Apesar desta temática ser abordada com bastante frequência na literatura utilizando estudos de caso e definições de tipologias e princípios de boas práticas, a participação pública no estado de São Paulo é guiada apenas pelas normas federais e estaduais, sem nenhum tipo de guia ou cartilha específicos sobre a participação e como ela deve ser trabalhada durante o processo. As normas vigentes no estado de São Paulo durante o Licenciamento Ambiental do Rodoanel preveem como forma de participação a publicidade das informações do processo e dos estudos ambientais, consulta pública aos órgãos envolvidos, a realização de audiências públicas e envolvimento do CONSEMA na definição do termo de referência e na tomada de decisão (SMA, 2004a; SMA2004b). Os resultados desta pesquisa descreveram os diferentes momentos participativos do processo de licenciamento ambiental no estado de São Paulo.

Alguns dos motivos que podem ter influenciado na participação foi esta legislação que esteve vigente no licenciamento do Trecho Oeste e dos trechos seguintes. Glasson e Salvador 
(2000) apontaram que existe uma grande lacuna entre a política e a implementação, entre os procedimentos de AIA e a prática de AIA; o que é evidente no processo de AIA do Trecho Oeste, que, mesmo amparado pelas normas de âmbitos federal e estadual, acabaram por demonstrar um baixo envolvimento do público, se restringindo apenas aos momentos das audiências públicas. Ao analisar as audiências públicas de três estudos de caso em países em desenvolvimento, Almer e Koontz (2004) apontaram que o papel das audiências acaba se restringindo ao que é exigido por lei e dificilmente vão além disso. No caso do Rodoanel, não foi muito diferente. Depois de analisar a dinâmica interna das audiências públicas do Trecho Oeste do Rodoanel, Alonso e Costa (2004) concluíram que elas não funcionaram como arenas deliberativas, não preencheram os critérios de publicidade e acessibilidade, sua localização limitou a participação de grupos afetados e serviram como um canal para informação das autoridades para os residentes locais e associações da sociedade civil sem gerar mudanças significantes no projeto original.

Outro problema de descompasso do Trecho Oeste foi a lacuna de informações disponíveis no processo, refletindo algumas evidências de que o empreendimento foi licenciado a todo custo, sem considerar todos os aspectos e impactos do projeto e sem a devida participação pública nas audiências e também a transparência do processo. Ao analisar o papel da participação pública na AIA na China, Tang et al. (2005) constataram que a falta de transparência e da participação democrática tornou o sistema de AIA suscetível aos interesses econômicos, prejudicando sua efetividade como um instrumento de proteção ambiental. Isso também pode ser observado no caso do Trecho Oeste do Rodoanel, pois os impactos decorrentes da implantação do empreendimento foram sentidos ao longo do tempo e acabaram gerando denúncias e judicialização que foram evidenciadas durante o processo do Trecho Sul, que aconteceu em seguida.

A complexidade do empreendimento e do local onde ele seria implantado também representam uma arena ideal para o surgimento de polêmicas. Na fala dos entrevistados e nos documentos do processo, o Trecho Sul foi o que mais caracterizou conflitos e embates, especialmente por conta da AAE, pelas preocupações com a expansão urbana nas áreas de mananciais do entorno do empreendimento, por envolver comunidades indígenas e por carregar o peso de questões mal resolvidas do Trecho Oeste que haviam se acumulado. Com relação à incorporação da AAE no processo na AIA de projetos do Rodoanel, Sánchez e Silva-Sánchez (2008) observaram que apesar de ser uma contribuição positiva e inovadora, o órgão ambiental estadual não demonstrou conhecimento no planejamento estratégico, resultando em uma aprovação acelerada do relatório da AAE que não representou um acordo 
entre as partes interessadas sobre questões estratégicas (SÁNCHEZ; SILVA-SÁNCHEZ, 2008).

Sobre os impactos nas áreas de mananciais do Trecho Sul do Rodoanel houve uma intensa mobilização social de associações de moradores e ONGs contra o empreendimento levantando o potencial da expansão da mancha urbana sobre áreas sensíveis. Estas preocupações foram sustentadas pelo estudo elaborado pelo LABHAB (2005) que expôs os impactos urbanísticos do Trecho Oeste, relacionando-os com o Trecho Sul e, ainda, argumentou que obras da magnitude do Rodoanel deveriam ser objeto de um significativo processo participativo para que a tomada de decisão fosse legítima e que era preciso definir quais eram os instrumentos mais adequados para o processo de concertação social. Os impactos urbanísticos também trouxeram descontentamento do público com relação aos impactos das desapropriações no Trecho Leste. Ao descrever as questões envolvidas sobre o deslocamento e reassentamento induzido por projetos, Vanclay (2017) afirma que a criação de infraestruturas de transporte, como rodovias e anéis rodoviários, podem causar um deslocamento considerável de pessoas e, mesmo que o reassentamento seja bem intencionado e planejado, ele produz um enorme impacto sobre as comunidades. Isso foi evidenciado nas manifestações por escrito feitas pelos afetados pelo Rodoanel, que alertaram sobre os problemas nas desapropriações e também sobre os problemas de infraestrutura nas moradias daqueles que permaneceram no entorno do empreendimento.

A problemática das comunidades indígenas foi evidente no Trecho Sul, pois o empreendedor tentou dar seguimento ao processo sem a oitiva dos povos afetados e sem realizar os devidos estudos etnoecológicos. De acordo com as análises sobre o envolvimento de comunidades indígenas no processo de Licenciamento Ambiental brasileiro realizadas por Hanna et al. (2014), a regulamentação no Brasil precisa de mecanismos que evitem o enviesamento no processo de AIA e que as empresas e os profissionais responsáveis por subestimar, fraudar ou manipular impactos sejam responsabilizados por seus atos. Ao estabelecer os princípios de boas práticas internacionais sobre povos indígenas e conhecimento tradicional, Croal eTetreault (2012) apontam que respeitar e incorporar a sabedoria tradicional indígena sobre seu território na avaliação de impacto é imperativo e útil para que o estudo seja abrangente, respeite as necessidades destes povos e preserve a cultura indígena no desenvolvimento do projeto. Apesar de a FUNAI exigir que um estudo etnoecológico fosse elaborado após a polêmica, a participação das comunidades indígenas não foi devidamente considerada no processo de AIA do Rodoanel. 
O caso do Rodoanel pode ser considerado participativo especialmente por envolver mobilização organizada das prefeituras dos municípios afetados, MP, sociedade civil, diversas associações de moradores, ONGs e outros órgãos envolvidos no processo que emitiram pareceres técnicos que compõem o processo de Licenciamento com AIA. Ao revisar a literatura sobre quem deveria participar de um processo de AIA, Glucker et al. (2013) afirma que as evidências sugerem que todos os interessados em um determinado projeto devem ser convidados a participar, mas que quanto mais pessoas e grupos envolvidos participam, mais difícil é satisfazer as diversas expectativas. O Trecho Norte apresentou grande mobilização por parte de associação de moradores e ONGs por estar inserido em uma região da Serra da Cantareira e também por ser o último dos trechos a ser licenciado, de modo que o histórico dos outros casos serviu como exemplo e, até os dias atuais, o empreendimento continua a gerar polêmica. Ao realizar um estudo comparativo na AIA de projetos realizados por organizações governamentais e não governamentais, Hasan et al. (2018) identificaram que a presença da hierarquia administrativa e social entre as partes interessadas permite que grupos dominantes assumam o controle sobre as decisões, impedindo a efetividade de um processo participativo; desta forma, as ONGs assumem o papel de apoiar grupos submissos a tornar suas demandas visíveis e ouvidas transformando o processo em uma prática de diálogo ou debate. A responsabilidade por realizar a participação pública deveria ser das autoridades públicas, entretanto, devido à inércia de implementação de um processo participativo generalizado, as ONGs desempenham um papel proativo no desenvolvimento de novas práticas de participação pública (RICHARDSON; DUSIK; JINDROVA, 1998).

Estas evidências documentais e a análise de conteúdo das entrevistas com os atores do processo de AIA do Rodoanel corroboram com as justificava da escolha pelo caso dos atores consultados na etapa do questionamento preliminar. Ao triangular os dados destas três fontes de informação, foi possível identificar o envolvimento de diversos atores que participaram em diferentes momentos dos processos. As diferentes formas de participação no processo contemplaram o acesso a informações sobre o empreendimento, realização de reuniões públicas com prefeituras dos municípios afetados, a participação do CONSEMA na definição do termo de referência e na tomada de decisão, manifestações por escrito dos interessados e a realização de audiências públicas que contaram com ampla participação da sociedade (ONGs, universidades, associações de moradores, sindicatos, comunidades indígenas e população afetada pelo empreendimento) e que levaram a discussões que parecem ter contribuído para o ajuste do projeto e o gerenciamento dos seus impactos. 
No entanto, cabe destacar que a presente pesquisa não buscou avaliar a efetividade desta participação, ou seja, a verificação se algo funciona conforme o planejado e atende aos objetivos para o qual foi projetado (SADLER, 1996) e ao cumprimento de metas estabelecidas para o processo em si, ou metas para o resultado ambiental a partir dele (ELLING, 2009). Este trabalho descreveu a participação envolvida no estudo de caso e a analisou por meio da identificação dos momentos participativos dos processos, da verificação do atendimento aos princípios de boas práticas propostos por Andreé et al. (2006) e da comparação com os objetivos de participação propostos por Glucker et al. (2013).

\subsection{Percepção dos entrevistados sobre a participação na AIA}

Nesta seção serão apresentados os resultados referentes ao tema da participação pública no processo de AIA e que foram obtidos durante a realização das entrevistas com as partes interessadas do processo de AIA do Rodoanel considerando as respostas das perguntas 1, 2, 3, 4 (itens c, d, e, f, g) e 5 do roteiro da entrevista semiestruturada (Apêndice A).

As respostas da pergunta "O que você acha do processo de licenciamento ambiental com AIA do estado de SP?" (Pergunta 1 do roteiro de entrevista) tenderam a uma análise positiva do processo, trazendo à tona a importância da AIA ser uma exigência legal para a implantação de grandes empreendimentos causadores de impactos. Ao responder esta pergunta, os entrevistados relataram que a prática da AIA no estado de São Paulo é avançada e conduzida com grande rigor técnico por conta do conhecimento acumulado e a capacidade dos profissionais envolvidos. O Entrevistado C5 apontou que, no período em que atuou com o processo de AIA em São Paulo, eram feitas muitas reclamações por parte da sociedade civil e as exigências do órgão ambiental retardavam a implantação dos empreendimentos, mas que isso deixaria o projeto melhor. Além desta percepção do processo, alguns dos entrevistados reconheceram que ainda existem pontos a serem melhorados e que é preciso seguir um caminho de constante aperfeiçoamento. As sugestões de melhorias levantadas pelos entrevistados serão tratadas no item 5.4.2 dos resultados.

Para auxiliar na análise das respostas da pergunta "O que você̂ entende por participação pública?" (Pergunta 2 do roteiro de entrevista) foi utilizado o software IRAMUTEQ de análise qualitativa dos dados. Foram consideradas as respostas de cada um dos 9 entrevistados nesta fase da pesquisa e foram gerados 9 segmentos de texto contabilizando um total de 1250 ocorrências de palavras. Para o processamento do corpus textual no software, foram excluídas palavras como artigos, preposições, conjunções e verbos que tinham uma alta frequência no texto, mas não exprimiriam significado relevante para interpretação da 
análise. A nuvem de palavras destacou os termos mais utilizados pelos atores entrevistados (Figura 15).

Figura 15 - Nuvem de palavras sobre a percepção da participação na AIA dos atores do Rodoanel

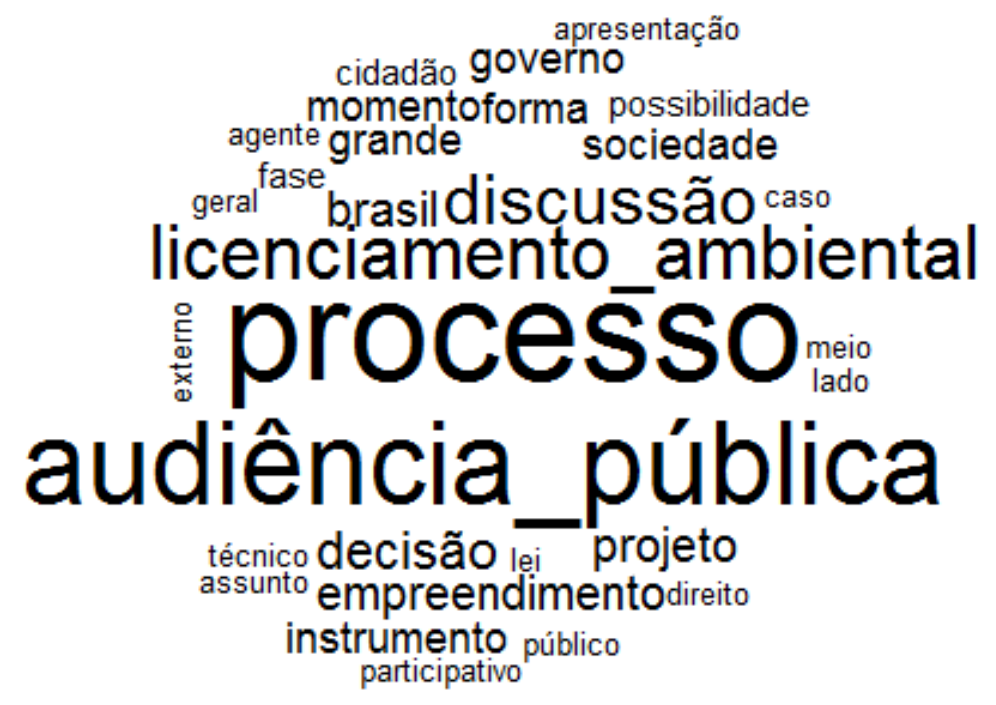

Fonte: Elaborado pela autora.

As palavras contempladas na nuvem tiveram ocorrência maior do que 3 citações em todas as respostas de todos os entrevistados, as quais iniciam com menor tamanho e aumentam proporcionalmente conforme o número de citações. As palavras "instrumento", "momento", "sociedade" e "governo" aparecerem cinco vezes e estão relacionadas com a percepção dos entrevistados em associar a participação pública como um instrumento que é utilizado em algum determinado momento do processo e que tem por objetivo envolver a sociedade na discussão de assuntos que lhes diz respeito antes que algo seja decidido. A palavra "governo" aparece nas respostas vinculadas diretamente à responsabilidade governamental para com a participação. As palavras "empreendimento" e "projeto" apareceram seis vezes e a palavra "decisão" apareceu sete vezes e foram empregadas no sentido da obrigatoriedade de envolver o público durante o processo de AIA de um empreendimento de modo que auxilie na tomada de decisão sobre o projeto. A palavra "discussão", citada dez vezes, foi utilizada no contexto de definir o que acontece durante um momento participativo, onde os interessados tomam seu papel na discussão dos temas em questão. A palavra "licenciamento ambiental" citada onze vezes apareceu nas entrevistas associadas ao processo de AIA e alguns atores a utilizaram como um sinônimo do processo de AIA. 
As palavras mais citadas entre os entrevistados foram "audiência pública", que apareceu dezoito vezes, e a palavra "processo" com vinte e três citações. Apesar da palavra "processo" aparecer em primeiro lugar na classificação, o contexto ao que ela se aplicava se referia ao processo de AIA, processo de decisão ou ao processo de licenciamento ambiental. Destas vinte e três citações, apenas quatro vincularam a palavra processo à participação pública e estas quatro foram identificadas na fala de um mesmo entrevistado (Entrevistado D1), mostrando que a maior parte dos entrevistados enxergam a participação mais como um momento específico do que como um processo. Nenhuma das respostas vinculou a palavra processo ao contexto judicial ou ao MP. No caso da palavra "audiência pública", o alto número de citações indica a percepção de que ela é a principal referência de participação para os atores entrevistados, assim como identificado nos resultados da pergunta 2 do questionamento preliminar, que indicaram a imediata associação do momento das audiências públicas com um processo considerado participativo.

Seguem alguns exemplos e detalhamento do entendimento sobre o que é participação apresentado pelos entrevistados. Entrevistado A1 definiu a participação pública como um direito e um dever e pontuou o seguinte:

Uma sociedade não se desenvolve sem a responsabilidade consciente de seus cidadãos. E o agir humano é inerente ao ato de existir. A participação pública é, portanto, a ação, o exercício livre do direito de tomar parte na condução (discussão, formulação, planejamento, execução) dos assuntos que definem o destino da sociedade (Entrevistado A1).

No caso do Entrevistado C5, o entendimento de participação pública se repousou apenas na figura das audiências públicas. No entanto, para os participantes A2, B1, C1, C2, C3 e D1, a descrição de suas percepções citou as audiências como um momento mais formal do processo, mas apontou que também existem outras formas, como, por exemplo a transparência das informações na publicidade e a consulta a outros órgãos. Os entrevistados C1 e C2 foram além e também reforçaram que, no Brasil, a participação não costuma acontecer nas etapas iniciais de definição de alternativas e, quando chega o momento das audiências públicas, as decisões já foram tomadas e o registro das audiências é usado para legitimar aquela decisão já tomada, perdendo o potencial transformador da participação. As deficiências das audiências também foram apontadas pelo entrevistado D1:

Por um lado, isso se tornou um instrumento mínimo para você conseguir brecar processo que são feitos à revelia de uma discussão maior da sociedade, a exigência da audiência pública ainda é o instrumento maior para garantir o processo participativo. Por outro lado, ela é facilmente manipulada. Ainda estamos longe de ter uma situação em que você realmente consiga promover e alavancar uma discussão da sociedade que tenha poder elaborativo e que influencie a tomada de decisão (Entrevistado D1). 
Quando questionados se a participação era importante para o processo de AIA (Pergunta 3 do roteiro de entrevista), todos os nove entrevistados responderam que sim e as principais justificativas foram que a participação é importante para decidir pela implantação ou não de um empreendimento, que o envolvimento do público permite a democratização da decisão, antecipa conflitos e auxilia o órgão ambiental a viabilizar a implantação de um empreendimento mais sustentável, minimizando os impactos inevitáveis. Também foi apontado que o momento participativo no processo de AIA representa um espaço para reivindicações dos interessados, para definir, denunciar, discutir a lógica do projeto com o objetivo de recolher ideias, sugestões e críticas que contribuem para a tomada de decisão. $\mathrm{O}$ entrevistado $\mathrm{C} 1$ justifica a importância de envolver o público no processo de AIA da seguinte forma:

Tem que se considerar que o processo de avaliação ambiental é hoje o principal instrumento de participação da sociedade em relação a determinados empreendimentos de grande impacto, ou seja, é o principal momento que a sociedade pode participar de um processo de decisão que pode afetar sua vida (Entrevistado C1).

Um outro aspecto relevante da importância levantado pelos participantes foi com relação a oportunidade de ouvir vários lados de uma mesma situação, absorvendo conhecimentos da população local para aperfeiçoar os projetos. Isso não é possível apenas com o conhecimento técnico, pois até mesmo o órgão ambiental não conhece todos os aspectos de uma determinada região.

Nas respostas da quarta pergunta (itens d, e, f, g, h) do roteiro de entrevistas, os atores expressaram suas percepções sobre a experiência individual durante o processo de AIA do Rodoanel. Apenas o Entrevistado C1 não respondeu às questões. Quando questionados se suas demandas ou se as demandas dos interessados foram ouvidas e/ou incorporadas no projeto do empreendimento, todos responderam que foram ouvidas, com exceção do entrevistado D1, que apontou que o processo foi um embate político e que suas demandas acabaram por não ser incorporadas no projeto e do entrevistado C5, que comentou que as “demandas levantadas nas audiências públicas foram certamente ouvidas, mas tinham coisas que não davam para levar em consideração, mas haviam solicitações que melhoraram o projeto e estas sim foram incorporadas".

Ao responderem às perguntas "Você gostou de participar" e "Você participaria de novo?", os entrevistados apontaram que sim, complementando com afirmações de que a experiência profissional em um processo de AIA de um megaprojeto como o do Rodoanel foi enriquecedora e trouxe muito aprendizado. O Entrevistado $\mathrm{C} 4$ respondeu dizendo que era uma 
obrigação participar por conta do cargo que ocupava, sem esclarecer se gostou ou se participaria de novo. No caso do Entrevistado D1, apesar de ter atuado no caso do Rodoanel representando a sociedade civil, ele não se considerou um participante do processo de AIA. Sua resposta apontou o seguinte: "Eu não participei diretamente do processo de aprovação, não me senti diretamente como um ator atuando de fato no licenciamento. Me senti como alguém que trouxe informações que eram contraditórias com os interesses dominantes".

As dificuldades em participar do processo de AIA do Rodoanel também foram apontadas pelos entrevistados na pergunta 4, e contemplaram elencando a governança por parte do poder público, a mediação de interesses conflitantes dos participantes, as demandas enviesadas levantadas em audiência pública que não se relacionam com a proposta do empreendimento, situações de tumultos e discussões ofensivas durante as audiências, dificuldades na interlocução entre o corpo técnico e a população leiga, politização dos debates, o tempo dispendido em audiência pública que a torna muito cansativa, desentendimentos com relação às desapropriações, dificuldades em definir o melhor horário e localização de audiências públicas, manifestações de interesses que visam benefício próprios e não coletivos. $\mathrm{O}$ Entrevistado C5 apontou como uma dificuldade a exigência para realização de estudos arqueológicos e etnoecológicos sobre as comunidades indígenas no Trecho Oeste. Sobre as dificuldades encontradas durante as audiências públicas de um processo de AIA, o Entrevistado A1 complementou sua resposta dizendo o seguinte:

No período pós-ditadura as pessoas não tinham liberdade de expressão e nem espaços nos quais pudessem se manifestar. Neste sentido, o meio ambiente prestou até um serviço à cidadania, porque os espaços das audiências públicas eram os espaços que as pessoas tinham para abrir a boca e poder falar. Aí acabavam colocando para fora, tudo o que tinha sido amordaçado, o que cabia e o que não cabia com relação àquele projeto que estava sendo discutido (Entrevistado A1).

Esta afirmação está relacionada com a opinião apresentava pelo Entrevistado B1, que disse que:

As audiências públicas ambientais são, muitas vezes, o único momento em que a comunidade participa ativamente de uma decisão sobre empreendimentos. Como é um dos poucos mecanismos de participação, as audiências acabam funcionando como um desaguadouro de outras reinvindicações, quem está no processo já sabe disso. Nas audiências públicas sempre têm grupos mais radicais que se posicionam, nem sempre com argumentação racional e técnica, e a equipe que está apresentando deve estar ciente de como evitar conflitos desnecessários (Entrevistado B1).

Considerando a experiência dos entrevistados no caso do Rodoanel e também em seu exercício profissional, foram solicitadas sugestões de melhoria para a participação pública no 
processo de AIA (Pergunta 5 do roteiro de entrevista). Dentre os 9 atores entrevistados, 8 responderam à pergunta.

Uma das respostas abordou a falta interesse da população em participar e que dependendo do governo em exercício a abertura para ouvir os interessados pode ser maior ou menor. Surgiram diversas recomendações para melhorar a participação no processo de AIA, como a execução do Zoneamento Ecológico Econômico (ZEE), que contemplaria informações para enriquecer a discussão e para direcionar a categoria do empreendimento que cabe ou não cabe numa determinada região. Também surgiram propostas de mudanças na elaboração de políticas públicas que vão além da obrigatoriedade da audiência pública no processo e que contemplem o envolvimento do público em momentos de discussões iniciais. A incorporação da AAE para oferecer uma análise mais ampla e não apenas por projeto individual apareceu como uma sugestão para melhoria do processo.

Uma das sugestões de cunho operacional da AIA que apareceu diversas vezes na fala dos entrevistados indicou a lacuna da fase de monitoramento do processo, na qual a implantação e acompanhamento das condicionantes apresenta deficiências e precisam ser melhoradas de modo a adotar medidas ativas para monitorar as atividades após a concessão da licença ambiental. Uma sugestão de melhoria apontada neste aspecto foi a criação de uma definição de natureza jurídica da obrigação das condicionantes. Outro aspecto apontado foi a necessidade de aprimorar o termo de referência, que deveria ser mais objetivo para que os empreendedores e consultores possam se aprofundar nos temas que realmente interessam, levando a elaboração de um EIA com mais evidências de participação popular. O RIMA também foi objeto de críticas nas respostas que salientaram a necessidade de o relatório portar uma linguagem de fácil entendimento do público e de serem utilizadas apresentações audiovisuais, que têm o potencial de transmitir informação de forma mais fácil ao público. Foi apontada a necessidade do EIA/RIMA estar acessível para consulta em mais locais e também utilizar a internet para ampliar a divulgação dos estudos e que também sejam disponibilizados com maior tempo de antecedência, pois o tempo estabelecido atualmente pode não ser suficiente para assimilação e formação de opinião das pessoas.

Também foi sugerido que a participação seja realizada na etapa de planejamento, antes da elaboração do EIA/RIMA, pois é o momento em que o projeto pode sofrer alteração e desta forma a qualidade dos estudos desenvolvidos seria melhor, poupando altos investimentos financeiros na elaboração de um estudo que seria posteriormente questionado. Desta forma, a morosidade do processo consequentemente seria atenuada. Mas, ainda que alguns atores tenham apontado essa lacuna, outros atores discordaram e apontaram que não 
seria necessário envolver o público na fase de elaboração do TR. Ao ser questionado se envolver a população nas etapas iniciais poderia favorecer o processo, o Entrevistado C3 apontou o seguinte:

Acho que não pois a população tem muitas perguntas não técnicas. Se for na fase do TR acho que não é fundamental pois o TR subsidia estudos técnicos. A população precisa ter algo para opinar em cima. Caso aconteça nessa fase inicial poderia ser apenas de pessoas que tivesse conhecimentos específicos da área, quem realmente possa contribuir de forma útil, mas geralmente a própria prefeitura local já é consultada nessa fase, autoridades. Mesmo nas audiências públicas você acaba filtrando pouca coisa que pode ser absorvida. A população poderia ser ouvida em uma fase anterior se tiver uma opinião muito certa e convicta de que ela não quer aquela obra de forma nenhuma, daí isso é importante pois você evitaria perder tempo estudando uma área que não vai conseguir implantar depois (Entrevistado C3).

Esta opinião corrobora com o que foi apontado pelo Entrevistado A1 e pelo Entrevistado

B1 sobre o envolvimento do público no início do processo de AIA, que apontaram o seguinte:

No período em que era feita audiência pública preliminar no processo de AIA em São Paulo, neste momento inicial de elaboração do TR, muitos estudos não tinham sido feitos ainda, e você não tinha respostas para determinadas perguntas, e isso aborrecia. Alguns dos participantes da audiência, que tinham conhecimento um pouco melhor de toda situação, começavam a reclamar, perguntando se estávamos de brincadeira, se queríamos que eles perdessem tempo chamando para discutir, sendo que o órgão licenciador, o proponente do projeto e a consultoria ainda não tinham dados, ainda não tinham mapas. Terminou-se por tomar a decisão de não se fazer essa audiência pública preliminar, pois se tornou mais motivo de aborrecimento do que de aprofundamento da matéria em discussão (Entrevistado A1).

Ao menos que setores específicos, ONGS, alguma entidade muito especializada em determinado assunto possa contribuir com alguma coisa no início do processo de AIA. Eu nunca senti falta de uma ausência de participação no início e que levou lá na frente a algum descuido com algum aspecto. E acho que o escopo que a CETESB tem, o manual de elaboração de AIA incorpora todos os aspectos. O importante mesmo é ao longo do desenvolvimento do trabalho você ter acesso a esses agentes externos como órgãos gestores de UCs, ONGs das regiões onde você vai estar licenciando, prefeituras municipais e seus órgãos de meio ambiente, esses conseguem contribuir com aperfeiçoamento dos projetos. Não acho que isso tem que ser objeto de uma obrigação, uma resolução, isso tem que ser construído pelo empreendedor junto aos interessados para viabilizar aquele empreendimento. Não precisamos de mais regras, precisamos de boas práticas, compromisso técnico e responsabilidade dos empreendedores e técnicos para desempenhar corretamente o processo, elaboração do projeto, ouvir os interessados (Entrevistado B1).

Sobre envolvimento do público em si, foram sugeridas melhorias no sentido de fomentar o acesso da população a recursos para encomendar estudos para elaborar uma avaliação, de aprimorar a divulgação das informações sobre o processo, e de fortalecer e qualificar a comunicação com a população especialmente durante as audiências pública, que, muitas 
vezes, não são utilizadas para comunicação, mas como um trampolim político e uma arena para conflitos de interesses.

A importância das pesquisas acadêmicas apontando os caminhos de aperfeiçoamento do processo também foi apontada como sugestão de melhoria pelo entrevistado A2:

Mais divulgação, maior representatividade, maior clareza do processo de AIA
e também a realização de pesquisas acadêmicas como esta, indicando quais
são as possibilidades. Também acredito que a utilização de ferramentas
eletrônicas de forma mais adequada pode ajudar em todo esse processo do
licenciamento. Para o órgão ambiental é preciso cada vez mais revisar esses
estudos, ir se atualizando. A consultoria ambiental também poderia estar mais
próxima do órgão licenciador, pois elas sempre pendem para o lado do
empreendedor. Já o empreendedor fica focado apenas em empreender sem ter
clareza do licenciamento, do processo, não dá para implantar sem ter uma boa
resposta ambiental, lembrar do desenvolvimento sustentável. E a academia
com certeza está na mira para formar opinião dessas pessoas todas
(Entrevistado A2).

A passagem acima traz aspectos gerais a serem modificados por diversas partes envolvidas em um processo de AIA e, de acordo com o entrevistado C3, o aperfeiçoamento é uma melhoria contínua, sempre absorvendo a experiência que já foi adquirida.

\subsubsection{Principais destaques}

A participação pública no processo de AIA é importante para que surjam contribuições para melhorar um projeto, de modo que diversos tipos de atores tragam para discussão questões socioambientais e culturais que muitas vezes não seriam passíveis de serem identificadas sob a perspectiva técnica. Diversos trabalhos têm retratado a importância de envolver o público em um processo de AIA, seus objetivos e as diferentes formas da participação. Este trabalho vem contribuir com a apresentação de um estudo de caso considerado participativo, descrevendo como a participação aconteceu e qual a percepção dos atores do processo de AIA sobre ela, já que o processo do Rodoanel foi considerado participativo.

Os atores do processo de AIA do Rodoanel associaram a participação pública com um momento específico do processo de AIA para envolver o público interessado no processo de tomada de decisão sobre um determinado empreendimento. Esta percepção esteve majoritariamente vinculada com a realização das audiências públicas, assim como a percepção dos atores que responderam à segunda pergunta do questionamento preliminar. Muitas vezes, a palavra audiência pública foi utilizada como um sinônimo de participação pública, o que é um equívoco. O momento das audiências públicas faz parte do rito processual da AIA estabelecido em normas legais e, de acordo com Almer e Koontz (2004), são úteis 
para fornecer informações sobre um projeto e para os cidadãos questionarem os envolvidos no projeto. No entanto, a participação vai além disso e, como definida por público O’Faircheallaigh (2010), pode ser vista como qualquer forma de interação que ocorre no processo de AIA entre os atores governamentais e corporativos e o público. Ainda assim, as ferramentas de participação pública normalmente utilizadas nas audiências públicas, reuniões e períodos de comentários têm um potencial de autonomia limitado (WIKLUND, 2005).

No estado de São Paulo, a participação das partes interessadas ainda pode ocorrer na forma de envolvimento do CONSEMA nas tomadas de decisão, manifestações por escrito dos interessados, a publicidade das informações e a consulta a outros órgãos ligados ao processo. Ao identificar os tipos de participação no estado do Espírito Santo, Faria e Silva (2017) constataram que as principais formas de envolver o público eram através da publicação em jornal, consulta prévia para realização do TR, audiência pública, referendo popular, envolvimento do CONSEMA no processo e por meio de comissões de acompanhamento após a emissão da licença ambiental.

A importância de envolver o público no processo de AIA foi afirmada pelos entrevistados e dentre os principais motivos estavam a contribuição para a tomada de decisão sobre um determinado empreendimento, antecipação de conflitos, minimização de impactos inevitáveis e a incorporação do conhecimento da população afetada sobre o local. Ao organizar o debate sobre a participação pública na AIA, Glucker et al. (2013) apontaram que influenciar decisões é um dos objetivos da participação, bem como a incorporação de conhecimentos locais e a resolução de conflitos. Apesar destes objetivos aparecerem nas respostas dos entrevistados ao descreverem a importância da participação, não foi a finalidade deste trabalho e nem foram estabelecidos mecanismos para confirmar se eles foram de fato alcançados no caso do Rodoanel ao analisar os documentos dos processos, já que isso seria uma avaliação da efetividade da participação.

Dentre outros objetivos da AIA apresentados por Glucker et al. (2013), foi possível identificar durante a análise documental dos processos dos quatro trechos do Rodoanel que dois deles foram atingidos, um deles é o objetivo de empoderar e emancipar grupos e indivíduos marginalizados. O grande número de manifestações por escrito, abaixo-assinados, envolvimento do MP, ONGs, associações de bairro e sociedade civil durante o Licenciamento Ambiental dos Trechos Sul, Leste e Norte indicaram que houve um fortalecimento de indivíduos e grupos marginalizados. Desta forma, estes grupos utilizaram o processo de AIA como uma forma de mudar a ordem social e levantar suas demandas (GLUCKER et al., 2013; O’FAIRCHEALLAIGH, 2010) e participaram de forma exaustiva no processo. 
As evidências documentais e os resultados obtidos pelas entrevistas permitiram identificar que o objetivo de legitimar o processo pela participação foi alcançado. No trabalho elaborado por Glucker et al. (2013), dar legitimidade à autoridade de AIA e facilitar a execução de um projeto é um dos objetivos da participação. Ao ver desta forma, é possível associar que a participação durante os processos dos Trechos Sul, Leste e Norte foram utilizadas para legitimar a tomada de decisão sobre a aprovação do empreendimento. No entanto, Dietz et al. (2008) definem legitimidade como "um processo que é visto pelos interessados e partes interessadas como justo e competente, e que segue as regulamentações e leis governamentais" e essa não foi a percepção de todos os atores entrevistados no caso do Rodoanel e do que foi retratado na literatura sobre o caso (ALONSO; COSTA, 2004; IACOVINI; ROLNIK, 2013; IACOVINI, 2015). Apesar da mobilização e envolvimento de diversas partes interessadas no processo de AIA do Rodoanel, de acordo com Iacovini e Rolnik (2013), a tônica básica ao longo de todo o processo de Licenciamento foi o embate polarizado entre ONGs e o poder público estadual, o que fez o processo se tornar desgastante a ponto de várias instituições da sociedade civil terem, aos poucos, abandonado o processo, restando poucas entidades engajadas até o final. Desta forma, a legitimidade do processo se deu pela visão do órgão ambiental e do empreendedor, que cumpriu com as exigências de participação previstas em lei, mas não necessariamente da população afetada pelo empreendimento.

Em resumo, a participação presente no caso do Rodoanel, que o fez ser considerado participativo pelos atores do processo, foi resultante das intervenções do MP (previstas no arcabouço constitucional para garantir os direitos ambientais, de participação e democráticos) e da mobilização social iniciada pelas partes interessadas, e não dos mecanismos de participação inerentes ao processo de AIA estabelecido em legislação, que em tese deveria garantir a participação considerando seus objetivos de empoderamento e emancipação, mas que, na prática, foi conduzido de forma mecânica nos momentos participativos previstos.

\subsubsection{Sugestões de melhorias para a participação na prática}

Por meio do viés técnico e prático dos entrevistados, também foram sugeridas melhorias para incorporar a participação do público no processo. Uma delas foi a necessidade de trabalhar a lacuna de participação na fase de monitoramento e acompanhamento das condicionantes de um empreendimento. Ao apresentar os princípios de boas práticas para a etapa de acompanhamento da AIA, Marshall et al. (2005) recomendam que a comunidade deveria ser envolvida nesta fase de forma que sejam informadas sobre os resultados do 
processo de AIA e que participem diretamente na concepção e implementação do programa de acompanhamento; desta forma, seria possível incorporar conhecimentos locais e construir parcerias de confiança. Esta afirmação corrobora com o apontado por Morrison-Saunders et al. (2003) que enfatizam o papel do envolvimento do público na etapa de acompanhamento especialmente em projetos controversos, pois além, de participar de atividades de monitoramento e mitigação, o público pode pressionar o proponente e o órgão ambiental a melhorar o projeto em operação.

Também apareceram sugestões para que a participação seja realizada na etapa de escopo, de modo a aprimorar o termo de referência e evitar altos investimentos financeiros durante a elaboração do EIA em aspectos não relevantes. Ao avaliar as práticas de escopo no processo de AIA federal no Brasil, Borioni et al. (2017) propuseram como melhoria para uma participação pública ausente ou insuficiente na etapa do escopo estabelecer prazos e procedimentos adequados para envolver comunidades afetadas e partes interessadas para identificar de forma colaborativa as preocupações e equilibrar valores. Apesar de ter acontecido a participação do CONSEMA na fase de elaboração do TR no caso do Rodoanel, o projeto ainda recebeu inúmeros pedidos de complementação e esclarecimento, o que acabou deixando o processo mais demorado e exigiu retrabalho por parte do proponente. Como observado por Fernández et al. (2018) ao analisarem o volume de informações de EIAs brasileiros, as consequências dos estudos não cumprirem com os requisitos de qualidade como abrangência, confiabilidade, compreensibilidade, clareza, acessibilidade e volume acabam por afetar aspectos de todo o processo de AIA, como o custo, tempo, as decisões tomadas e a participação.

Contemplar diretrizes para elaboração de um RIMA com linguagem de fácil entendimento para o público também foi recomendado pelos entrevistados, bem como a necessidade do EIA/RIMA estar acessível para consulta em um número maior de locais físicos e também disponível na internet. Os entrevistados também apontaram que o tempo estabelecido para consulta ao EIA/RIMA em legislação pode não ser suficiente para assimilação e formação de opinião das pessoas. Estes aspectos estão relacionados com a transparência e comunicação de um processo de AIA. Ao analisar a incerteza nas previsões da AIA, Tennøy et al. (2006) argumentam que se a comunicação for falha e o processo não for transparente é provável que informações valiosas não sejam trazidas para discussão e as decisões acarretem em consequências indesejáveis ou, até, que a influência democrática seja impedida pela falta de informações. O aprimoramento da divulgação das informações sobre o processo, a qualificação da comunicação com a população especialmente durante as 
audiências pública são essenciais para fortalecer a participação e elevar o nível das discussões durante um processo de AIA.

A realização de pesquisas acadêmicas sobre o tema da participação também surgiu como uma contribuição necessária para dar suporte à prática. No entanto, como ressaltado na pesquisa realizada por Duarte et al. (2017b), é preciso produzir conhecimento robusto sobre o tema da AIA para combater suas fragilidades sem comprometer práticas de sucesso, de modo que no futuro as evidências científicas possam embasar debates e propostas. 


\section{CONSIDERAÇÕES FINAIS}

Esta pesquisa teve por objetivo descrever e analisar o processo de participação pública no estado de São Paulo, utilizando o estudo de caso do Rodoanel, sob a percepção do que é um processo de AIA considerado participativo.

Entre os casos citados pelas partes interessadas no questionamento preliminar, o processo de AIA do Rodoanel foi considerado o mais participativo por levantar questionamentos acerca da justificativa do empreendimento, da concepção do projeto, dos impactos ambientais e urbanísticos decorrentes da sua implantação e, com isso, envolver diferentes atores e apresentar mobilização social organizada pelos interessados. Estas razões o fizeram ser o processo de AIA mais citado e o escolhido para o estudo de caso.

A percepção dos atores do processo de AIA sobre a participação pública é de que ela se refere mais a um momento específico do que a um processo. Isso se relaciona diretamente com a forte associação que estes atores fizeram da participação com o momento das audiências públicas, muitas vezes, utilizando o termo para se referir à participação como se fossem sinônimos. Os atores entrevistados consideraram que a participação é importante e compreende em uma oportunidade de os interessados exercerem seu papel de cidadão na discussão de temas que lhes dizem respeito. Na perspectiva deles, o processo de AIA do estado de São Paulo é bom, mas ainda existe muito a ser melhorado.

Com base no estudo de caso do Rodoanel, o processo de AIA do estado de São Paulo apresenta como mecanismos de participação na etapa do escopo, a publicidade das informações e a atuação do CONSEMA para definição do TR. Na etapa da análise técnica sobre o EIA/RIMA, o envolvimento do público acontece na forma de publicidade dos estudos, na possibilidade do envio de manifestações por escrito dos interessados, na consulta a outros órgãos ligados ao processo, na forma de realização de reuniões públicas promovidas pelas prefeituras dos municípios envolvidos e nas audiências públicas. Na etapa de tomada da decisão, a participação ocorre por meio do parecer do CONSEMA sobre a viabilidade ambiental do empreendimento e pela publicidade das informações sobre a aprovação do projeto e posterior emissão da LP.

O processo de AIA no estado de São Paulo apresentou avanços no período em que aconteceu o licenciamento ambiental do Rodoanel Mário Covas, desde a concepção do Trecho Oeste em 1997, durante o Trecho Sul em 2004 e do Trecho Leste em 2009, até o Trecho Norte em 2010. Desta forma, no processo de Licenciamento do primeiro trecho, a participação aconteceu no momento das audiências públicas, apenas no que era exigido por lei, falhando na publicidade, transparência das informações. O processo do Trecho Sul 
representa um marco, pois evidenciou todos os problemas gerados pela negligência de não envolver o público no Licenciamento do trecho anterior. Neste momento, também emergiram intensos debates sobre os impactos ambientais e da ocupação urbana que poderiam ocorrer decorrentes do projeto e estas discussões envolveram associações de moradores, sindicatos, ONGs, sociedade civil e comunidades indígenas. No processo do Trecho Leste, o debate continuou envolvendo as mesmas categorias de atores, desta vez, evidenciando os impactos urbanos do traçado, utilizando como exemplo os problemas que já haviam sido sentidos pelas comunidades afetadas pelos traçados já implantados. No processo do Trecho Norte, o debate manteve as categorias de atores na discussão, que utilizaram outros traçados como um aprendizado e apresentaram uma mobilização social organizada por parte de associação de moradores, ONGs e prefeituras dos municípios envolvidos. Cabe destacar que este aprendizado ao longo do processo não necessariamente reflete a situação atual, já que, posteriormente, ocorreram mudanças na legislação estadual no que diz respeito à participação, conforme apontado na revisão de literatura.

Os processos de licenciamento com AIA do Rodoanel, com exceção do Trecho Oeste, podem ser considerados participativos, pois foram encontradas evidências documentais de participação, envolveram diversas partes interessadas, indivíduos ou grupos que se mobilizaram e se empoderaram utilizando os momentos em que a participação era prevista na legislação e, principalmente, recorrendo a instâncias externas ao processo de licenciamento e AIA, como o MP. Este resultado explica as possíveis razões de o caso do Rodoanel ter sido citado como participativo no questionário preliminar realizado na primeira etapa desta pesquisa.

Apesar de o processo ser considerado participativo sob a perspectiva da mobilização social, foram identificados alguns problemas na prática da participação pública que corroboram com o que vem sendo apontado na literatura sobre o tema. Entre os principais entraves estão a falta de envolvimento da comunidade afetada na definição do TR, problemas no conteúdo do EIA de modo a subestimar os impactos socioambientais às comunidades indígenas, o conteúdo técnico e linguagem não acessível do RIMA, falhas na comunicação e transparência das informações, problemas na dinâmica das audiências públicas e ausência de participação na fase de acompanhamento e monitoramento do empreendimento. Por essas barreiras estarem associadas com a condução do processo pelo órgão ambiental e com a elaboração do projeto por parte do proponente, as evidências deste estudo de caso servem como um exemplo de lições aprendidas, indicando o que foi positivo e negativo no envolvimento do público durante o processo de AIA de um empreendimento linear de grande 
porte. Com base na experiência do Rodoanel, é possível perceber o potencial do envolvimento popular e que deveria ser melhor aproveitado. Essa melhoria pode ser realizada a partir do design de um processo de participação que acompanhe de forma paralela o processo de AIA, funcionando como um guia para adequação dos momentos participativos previstos legalmente e apontando as melhores ferramentas a serem utilizadas em cada etapa do processo de AIA.

A partir da descrição e análise da participação no estudo de caso foi possível identificar os momentos em que o público é envolvido, as formas utilizadas para que a participação aconteça, a percepção de atores sobre ela e os motivos pelos quais um processo de AIA é considerado participativo.

Com a realização desta pesquisa e da indicação de possíveis melhorias para envolver o público durante um processo de AIA, é esperado que estes resultados sirvam como embasamento para a elaboração de práticas melhores de participação que tragam contribuições efetivas para a tomada de decisão. Assim, seria possível conceber mecanismos específicos para cada etapa do processo com o propósito de informar a população de forma transparente e utilizando uma linguagem clara e acessível a todos, com o objetivo de qualificar a discussão e de considerar as diversas demandas e perspectivas das diferentes categorias de atores, respeitando os valores e a cultura de povos tradicionais, dando a devida importância ao contexto das comunidades afetadas por um empreendimento. 


\section{REFERÊNCIAS}

ABAZA, Hussein; BISSET, Ron; SADLER, Barry. Environmental Impact Assessment and Strategic Environmental Assessment: Towards an Integrated Approach. [s.l: s.n.]. Disponível em: http://www.unep.ch/etu/publications/textONUbr.pdf.

ALMER, Heather L.; KOONTZ, Tomas M. Public hearings for EIAs in post-communist Bulgaria: Do they work? Environmental Impact Assessment Review, [S. l.], v. 24, n. 5, p. 473-493, 2004. DOI: 10.1016/j.eiar.2003.12.004.

ALONSO, Angela; COSTA, Valeriano. The dynamics of Public Hearings for Environmental Licensing: The case of the São Paulo ring road. IDS Bulletin, [S. l.], v. 35, n. 2, p. 49-57, 2004. DOI: 10.1111/j.1759-5436.2004.tb00121.x.

ANDRÉ, P.; ENSERINK, B.; CONNOR, D.; CROAL, P. Public Participation: International Best Practice Principles. Special Publication Series No. 4. [s.l: s.n.]. Disponível em: www.iaia.org.

ARNSTEIN, Sherry R. A Ladder Of Citizen Participation. Journal of the American Planning Association, $[S . \quad$ l. $], \quad$ v. 35, n. 4, p. 216-224, 1969. DOI: 10.1080/01944366908977225.

ARTS, Jos; TOMLINSON, Paul; VOOGD, Henk. Planning in tiers? Tiering as a way of linking SEA and EIA. In: SADLER, B., DUSIK, J., FISCHER, T., PARTIDARIO, M., VERHEEM, R. \& ASCHEMANN, R. (org.). Handbook of Strategic Environmental Assessment. [s.1.] : CRC Press, 2012. p. 415-433.

BARDIN, Laurence. Análise de Conteúdo. [s.1.] : Edições 70, 1977. Disponível em: http://books.google.com/books?id=AFpxPgAACAAJ\%5Cnhttp://cliente.argo.com.br/ mgo s/analise_de_conteudo_moraes.html\#_ftn1.

BOBBIO, Luigi. Designing effective public participation. Policy and Society, [S. l.], v. 38, n. 1, p. 41-57, 2019. DOI: 10.1080/14494035.2018.1511193. Disponível em: https://www.tandfonline.com/doi/full/10.1080/14494035.2018.1511193. Acesso em: 6 nov. 2020.

BORIONI, Rossana; GALLARDO, Amarilis Lucia Casteli Figueiredo; SÁNCHEZ, Luis Enrique. Advancing scoping practice in environmental impact assessment: an examination of the Brazilian federal system. Impact Assessment and Project Appraisal, [S. l.], p. 1-14, 2017. DOI: 10.1080/14615517.2016.1271535. Disponível em: https://www.tandfonline.com/doi/full/10.1080/14615517.2016.1271535. Acesso em: 7 nov. 2018.

BOWEN, Glenn A. Document Analysis as a Qualitative Research Method. Qualitative Research Journal, [S. l.], v. 9, p. 27-40, 2009. DOI: 10.3316/QRJ0902027. Disponível em: http://www.rmitpublishing.com.au/qrj.html. Acesso em: 24 nov. 2020.

BRASIL. Lei $\mathbf{N}^{\circ}$ 6.938, de 31 de agosto de 1981. Dispõe sobre a Política Nacional do Meio Ambiente, seus fins e mecanismos de formulação e aplicação, e dá outras providências. Brasília, DF, 1981.

BRASIL. Constituição da República Federativa do Brasil de 1988. Brasília, DF, 1988.

BRASIL. Lei Complementar $N^{0}$ 140, de 8 de dezembro de 2011. Fixa normas para a cooperação entre a União, os Estados, o Distrito Federal e os Municípios nas ações administrativas decorrentes do exercício da competência comum relativas à proteção das paisagens naturais notáveis, à proteção do meio ambiente, ao combate à poluição em qualquer 
de suas formas e à preservação das florestas, da fauna e da flora; e altera a Lei no 6.938, de 31 de agosto de 1981.

BRASIL. Decreto $n^{0}$ 8.243, de 23 de maio de 2014. Institui a Política Nacional de Participação Social - PNPS e o Sistema Nacional de Participação Social - SNPS, e dá outras providências. Brasília, DF, 2014.

BRASIL. Decreto No 9.759, de 11 de abril de 2019. Extingue e estabelece diretrizes, regras e limitações para colegiados da administração pública federal. Brasília, DF, 2019.

BROMBAL, Daniele; MORIGGI, Angela; MARCOMINI, Antonio. Evaluating public participation in Chinese EIA. An integrated Public Participation Index and its application to the case of the New Beijing Airport. Environmental Impact Assessment Review, [S. l.], v. 62, p. 49-60, 2017. DOI: 10.1016/J.EIAR.2016.07.001. Disponível em: https://www.sciencedirect.com/science/article/pii/S0195925516300658?via\%3Dihub.

Acesso em: 11 abr. 2018.

CAMARGO, Brígido V.; JUSTO, Ana M. IRAMUTEQ: Um software gratuito para análise de dados textuais. Temas em Psicologia, [S. l.], v. 21, n. 2, p. 513-518, 2013. DOI: 10.9788/tp2013.2-16.

CASHMORE, Matthew; RICHARDSON, Tim. Power and environmental assessment: Introduction to the special issue. Environmental Impact Assessment Review, [S. l.], v. 39, p. 1-4, 2013. DOI: 10.1016/J.EIAR.2012.08.002. Disponível em: https://www.sciencedirect.com/science/article/pii/S0195925512000765. Acesso em: 23 out. 2018.

CETESB. Processo No 13.522 de 1997. Rodoanel Trecho Oeste. São Paulo, SP, 1997.

CETESB. Processo No 13730 de 2004. Rodoanel Trecho Sul. São Paulo, SP, 2004.

CETESB. Processo No 6563 de 2009. Rodoanel Trecho Leste. São Paulo, SP, 2009.

CETESB. Processo No 208 de 2010. Rodoanel Trecho Norte. São Paulo, SP. 2010.

CETESB. Informação técnica $\mathbf{n}^{\mathbf{0}} \mathbf{7 7 1 9 6 / 0 9 / T A G A}$ em resposta ao Despacho Especial CONSEMA nº 039/2009. São Paulo, SP, 2009.

CETESB. Decisão de Diretoria $\mathbf{N}^{\circ}$ 153/2014/I, de 28 de maio de 2014. Dispõe sobre os Procedimentos para o Licenciamento Ambiental com Avaliação de Impacto Ambiental no Âmbito da CETESB, e dá outras providências. São Paulo, SP, 2014.

CHAMBLISS, Daniel F.; SCHUTT, Russell K. Making Sense of the Social World: Methods of Investigation. 6e. ed. [s.1.] : SAGE Publications, 2018. Disponível em: https://books.google.com.br/books?hl=pt-

BR\&lr=\&id=jnl_DwAAQBAJ\&oi=fnd\&pg=PP1\&dq=survey + methods + in + social + investig ation\&ots $=$ bclP-

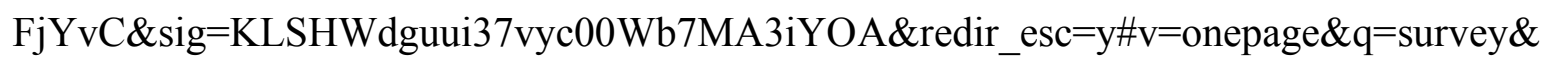
$\mathrm{f}=$ false. Acesso em: 17 nov. 2020.

CODESP. Complexo Portuário de Santos. Porto de Santos. Disponível em: http://www.portodesantos.com.br/conheca-o-porto/o-porto-de-santos/. Acesso em: dezembro. 2020.

CONAMA. Resolução CONAMA $\mathbf{N}^{0} \mathbf{0 0 1}$, de 23 de janeiro de 1986. Estabelece as definições, as responsabilidades, os critérios básicos e as diretrizes gerais para uso e implementação da Avaliação de Impacto Ambiental como um dos instrumentos da Política Nacional do Meio Ambiente. Ministério do Meio Ambiente, Brasília, DF, 1986. 
CONAMA. Resolução CONAMA no 9, de 3 de dezembro de 1987. Dispõe sobre a realização de Audiências Públicas no processo de licenciamento ambiental. Brasília, DF, 1987.

CONAMA. Resolução CONAMA No 237 , de 19 de dezembro de 1997. Estabelece procedimentos, critérios e competências no licenciamento ambiental. Ministério do Meio Ambiente, Brasília, DF, 1997.

CROAL, P.; TETREAULT, C. Respecting Indigenous Peoples and Traditional Knowledge. Special Publication Series No. 9, [S. l.], 2012. Disponível em: www.iaia.org.

DERSA. Mapa dos trechos Norte, Leste, Sul e Oeste do Rodoanel. Plano de Trabalho do EIA/RIMA do Rodoanel de São Paulo. Dezembro, 2000.

DERSA. Carta resposta da Solicitação de alteração de data de audiência pública Rodoanel Norte (CE-PR 230/2010). Novembro, 2010.

DIETZ, Thomas.; STERN, Paul C. Public participation in environmental assessment and decision making. Panel on P ed. Washington, D.C.: National Academies Press, 2008.

DUARTE, Carla Grigoletto; FERREIRA, Victoria Helena; SÁNCHEZ, Luis Enrique. Analisando audiências públicas no licenciamento ambiental: Quem são e o que dizem os participantes sobre projetos de usinas de cana-de-açúcar. Saude e Sociedade, [S. 1.], v. 25, n. 4, p. 1075-1094, 2016. DOI: 10.1590/S0104-12902016151668.

DUARTE, Carla Grigoletto; DIBO, Ana Paula Alves; SIQUEIRA-GAY, Juliana; SÁNCHEZ, Luis Enrique. Practitioners' perceptions of the Brazilian environmental impact assessment system: results from a survey. Impact Assessment and Project Appraisal, [S. 1.], v. 35, n. 4, p. 293-309, 2017. a. DOI: 10.1080/14615517.2017.1322813. Disponível em: https://www.tandfonline.com/doi/full/10.1080/14615517.2017.1322813. Acesso em: 7 nov. 2018.

DUARTE, Carla Grigoletto; PAULA, Ana; DIBO, Alves; SÁNCHEZ, Luis Enrique. O que diz a pesquisa acadêmica sobre avaliação de impacto e licenciamento ambiental no Brasil? Ambiente \& Sociedade, [S. l.], v. XX, p. 247-278, 2017. b.

EC. Proposal for a Directive of the European Parliament and of the Council on access to justice in environmental matters. Comission of the European Communities. Brussels, 2003. Disponível em: https://eur-lex.europa.eu/legalcontent/EN/TXT/PDF/?uri=CELEX:52003PC0624\&from=EN. Acesso em: fevereiro.2021.

EMPLASA. Mapa do Rodoanel: Trechos e municípios envolvidos. Relatório de apresentação do Rodoanel: Anel de integração metropolitana. DERSA e EMPLASA. Novembro, 1996.

EMPLASA. Região Metropolitana de São Paulo (RMSP). São Paulo, SP, 2020. Disponível em: https://emplasa.sp.gov.br/RMSP. Acesso em: outubro. 2020.

FARIA, Giulianna Calmon; SILVA, Fátima Maria. Participação pública no processo de avaliação de impacto ambiental no estado do Espírito Santo. Desenvolvimento e Meio Ambiente, [S. l.], v. 43, 2017. DOI: 10.5380/dma.v43i0.54188.

FERNÁNDEZ, Germán Marino Rivera; DE BRITO, Ludmila Ladeira Alves; FONSECA, Alberto. Does size matter? An evaluation of length and proportion of information in environmental impact statements. Environmental Impact Assessment Review, [S. l.], v. 73, p. 114-121, 2018. DOI: 10.1016/j.eiar.2018.08.002.

FESPSP. Relatório de impacto ambiental (RIMA) - Programa Rodoanel Mario Covas: 
Trecho Sul Modificado. Fundação Escola de Sociologia e Política de São Paulo. Outubro, 2004.

FISCHER, Thomas B. Environmental Assessment of Policies, Plans, Programmes and Projects (Module Textbook). Liverpool.

FISCHER, Thomas; PHYLIP-JONES, John. Scoping in environmental assessment. In: FISCHER, T. B.; GAZZOLA, P.; JHA-THAKUR, U.; BELCAKOVA, I. AND ASCHEMANN, R. (org.). Environmen ed. [s.1.] : Bratislava: ROAD, 2008. p. 136-142. Disponível em: http://www.snh.org.uk/publications/online/heritagemanagement/EIA/guidance2.shtml. Acesso em: 29 out. 2020.

FITZPATRICK, Patricia; SINCLAIR, A. John. Learning through public involvement in environmental assessment hearings. Journal of Environmental Management, [S. l.], v. 67, n. 2, p. 161-174, 2003. DOI: 10.1016/S0301-4797(02)00204-9.

FONSECA, Alberto; SÁNCHEZ, Luis Enrique; RIBEIRO, José Claudio Junqueira. Reforming EIA systems: A critical review of proposals in Brazil. Environmental Impact Assessment Review, [S. l.], v. 62, p. 90-97, 2017. DOI: 10.1016/J.EIAR.2016.10.002. Disponível em: https://www.sciencedirect.com/science/article/pii/S0195925516301639. Acesso em: 8 jul. 2018.

FOUCAULT, Michel. The ethic of care for the self as a practice of freedom. In The Final Foucault, eds. J. Bernauer \& D. Rasmussen. Cambridge: MIT Press, 1988.

FRANCO, Maria Laura P. B. Análise de conteúdo Volume 6. 2d. ed. [s.1.] : Liber Livro Editora Ltda., 2007.

FREITAS, Henrique; OLIVEIRA, Mirian; SACCOL, Amarolinda; MOSCAROLA, Jean. O Método de pesquisa SurveyRevista de Administração, 2000. Disponível em: www.rausp.usp.br/download.asp?file=3503105.pdf?

FUNDINGSLAND TETLOW, Monica; HANUSCH, Marie. Strategic environmental assessment: The state of the art. Impact Assessment and Project Appraisal, [S. l.], v. 30, n. 1, p. 15-24, 2012. DOI: 10.1080/14615517.2012.666400.

GLASSON, John; SALVADOR, Nemesio Neves B. EIA in Brazil: A procedures-practice gap. A comparative study with reference to the European Union, and especially the UK. Environmental Impact Assessment Review, [S. l.], v. 20, n. 2, p. 191-225, 2000. DOI: 10.1016/S0195-9255(99)00043-8.

GLASSON, John; THERIVEL, Riki; CHADWI, Andrew. Introduction to environmental impact assessment. 3rd. ed. [s.1.] : Routledge, 2005. DOI: 10.4324/9780429470738.

GLUCKER, Anne N.; DRIESSEN, Peter P. J.; KOLHOFF, Arend; RUNHAAR, Hens A. C. Public participation in environmental impact assessment: why, who and how? Environmental Impact Assessment Review, [S. l.], v. 43, p. 104-111, 2013. DOI: 10.1016/J.EIAR.2013.06.003. em: https://www.sciencedirect.com/science/article/pii/S0195925513000711. Acesso em: 11 abr. 2018.

HABERMAS, Jiirgen. The theory of communicative action - Volume 2 - Lifeworld and system: a critique of functionalist reason. 3 ed. ed. Boston: Beacon Press, 1987.

HANNA, Philippe; VANCLAY, Frank; LANGDON, Esther Jean; ARTS, Jos. Improving the effectiveness of impact assessment pertaining to Indigenous peoples in the Brazilian environmental licensing procedure. Environmental Impact Assessment Review, [S. l.], v. 46, p. 58-67, 2014. DOI: 10.1016/j.eiar.2014.01.005. 
HARTLEY, Nicola; WOOD, Christopher. Public participation in environmental impact assessment-implementing the Aarhus Convention. Environmental Impact Assessment Review, [S. l.], v. 25, n. 4, p. 319-340, 2005. DOI: 10.1016/J.EIAR.2004.12.002. Disponível em: https://www.sciencedirect.com/science/article/pii/S019592550400160X. Acesso em: 17 abr. 2018.

HASAN, Md Arif; NAHIDUZZAMAN, Kh Md; ALDOSARY, Adel S. Public participation in EIA: A comparative study of the projects run by government and nongovernmental organizationsEnvironmental Impact Assessment ReviewElsevier Inc., , 2018. DOI: 10.1016/j.eiar.2018.05.001.

HOURDEQUIN, Marion; LANDRES, Peter; HANSON, Mark J.; CRAIG, David R. Ethical implications of democratic theory for U.S. public participation in environmental impact assessment. Environmental Impact Assessment Review, [S. l.], v. 35, p. 37-44, 2012. DOI: 10.1016/j.eiar.2012.02.001.

IACOVINI, Rodrigo Faria Gonçalves. Os (Des)caminhos do processo decisório do Rodoanel Mário Covas (SP). Anais XVI ENANPUR, [S. l.], v. Estado, pl, p. 1-16, 2015. Disponível em: www.teses.usp.br. Acesso em: 13 dez. 2020.

IACOVINI, Rodrigo Faria Gonçalves; ROLNIK, Raquel. Rodoanel Mário Covas Atores, Arenas e Processos. 2013. Universidade de São Paulo, [S. l.], 2013.

IAIA. Principles of environmental impact assessment, best practice. International Association for Impact Assessmen, [S. l.], p. 1-4, 1999. Disponível em: http://scholar.google.com/scholar?hl=en\&btnG=Search\&q=intitle:PRINCIPLES+OF+ENV IRONMENTAL+IMPACT+ASSESSMENT+BEST+PRACTICE\#4.

IBGE. IBGE divulga estimativa da população dos municípios para 2020. Estatísticas Sociais. Agência IBGE Notícias. Disponível em: https://agenciadenoticias.ibge.gov.br/agencia-sala-de-imprensa/2013-agencia-denoticias/releases/28668-ibge-divulga-estimativa-da-populacao-dos-municipios-para-2020. Acesso em: novembro. 2020a.

IBGE. Estado de São Paulo. Panorama. Disponível em: https://cidades.ibge.gov.br/brasil/sp/sao-paulo/panorama. Acesso em: novembro. 2020b.

IPEA. Relatório Participação Social na Administração Pública Federal: Desafios e perspectivas para a criação de uma Política Nacional de Participação. Projeto Apoio aos diálogos setoriais União Europeia - Brasil, 2013. Disponível em: https://www.ipea.gov.br/participacao/images/pdfs/participacao/participacao\%20social\%20n a\%20administracao\%20publica\%20federal.pdf. Acesso em: outubro. 2020.

JOHNSON, Thomas. Public participation in China's EIA process and the regulation of environmental disputes. Environmental Impact Assessment Review, [S. l.], v. 81, p. 106359, 2020. DOI: 10.1016/j.eiar.2019.106359.

LAWRENCE, David P. Impact Assessment: Practical Solutions to Recurrent Problems and Contemporary Challenges. 2d. ed. [s.1.] : John Wiley \& Sons, Inc., 2013. DOI: 10.1177/0193841X9401800105.

LEE, Maria; ABBOT, Carolyn. The Usual Suspects? Public Participation Under the Aarhus Convention. Modern Law Review, [S. l.], v. 66, n. 1, p. 80-108, 2003. DOI: 10.1111/14682230.6601004. Disponível em: http://doi.wiley.com/10.1111/1468-2230.6601004. Acesso em: 30 abr. 2018.

MACHADO, Paulo Affonso Leme. Direito Ambiental Brasileiro. 21 ed. ed. [s.1.] : 
Malheiros Editores, 2013. Disponível em: https://www.facebook.com/geografiaacademica. Acesso em: 8 mar. 2021.

MARSHALL, Ross; ARTS, Jos; MORRISON-SAUNDERS, Angus. International principles for best practice EIA follow-up. Impact Assessment and Project Appraisal, [S. l.], v. 23, n. 3, p. 175-181, 2005. DOI: 10.3152/147154605781765490. Disponível em: https://www.tandfonline.com/doi/abs/10.3152/147154605781765490. Acesso em: 28 out. 2020.

MARTIN, Terri. Muting the Voice of the Local in the Age of the Global: How Communication Practices Compromised Public Participation in India's Allain Dunhangan Environmental Impact Assessment. Environmental Communication, [S. l.], v. 1, n. 2, p. 171-193, 2007. DOI: 10.1080/17524030701642595. Disponível em: https://www.tandfonline.com/doi/abs/10.1080/17524030701642595. Acesso em: 15 set. 2020.

MAUERHOFER, Volker. Public participation in environmental matters: Compendium, challenges and chances globally. Land Use Policy, [S. l.], v. 52, p. 481-491, 2016. DOI: Disponível em: https://www.sciencedirect.com/science/article/pii/S026483771500054X?via\%3Dihub. Acesso em: 9 abr. 2018.

MILLS, Albert J.; DUREPOS, Gabrielle; WIEBE, Elden. Encyclopedia of Case Study Research. [s.l.] : SAGE Publications, 2009. Disponível em: https://books.google.com.br/books?id=6omECgAAQBAJ\&printsec=frontcover\&hl=pt-

BR\&source $=\mathrm{gbs}$ ge_summary_r\&cad $=0 \# \mathrm{v}=$ onepage $\& \mathrm{q} \& \mathrm{f}=$ false. Acesso em: 24 nov. 2020 .

MONTAÑO, Marcelo; DE SOUZA, Marcelo Pereira. Impact assessment research in Brazil: Achievements, gaps and future directionsJournal of Environmental Assessment Policy and ManagementWorld Scientific Publishing Co. Pte Ltd, , 2015. DOI: 10.1142/S146433321550009X.

MORGAN, Richard K. Environmental impact assessment: The state of the artImpact Assessment and Project Appraisal TF, 2012. DOI: 10.1080/14615517.2012.661557. Disponível em: https://www.tandfonline.com/doi/abs/10.1080/14615517.2012.661557. Acesso em: 22 out. 2020.

MORRISON-SAUNDERS, Angus; BAKER, Jill; ARTS, Jos. Lessons from practice: Towards successful follow-up. Impact Assessment and Project Appraisal, [S. l.], v. 21, n. 1, p. 43-56, 2003. DOI: 10.3152/147154603781766527. Disponível em: https://www.tandfonline.com/action/journalInformation?journalCode=tiap20. Acesso em: 11 jan. 2021.

NADEEM, Obaidullah; FISCHER, Thomas B. An evaluation framework for effective public participation in EIA in Pakistan. Environmental Impact Assessment Review, [S. l.], v. 31, n. 1, p. 36-47, 2011. DOI: 10.1016/j.eiar.2010.01.003.

O'FAIRCHEALLAIGH, Ciaran. Public participation and environmental impact assessment: Purposes, implications, and lessons for public policy making. Environmental Impact Assessment Review, [S. l.], v. 30, n. 1, p. 19-27, 2010. DOI: 10.1016/J.EIAR.2009.05.001. Disponível em: https://www.sciencedirect.com/science/article/pii/S0195925509000845?via\%3Dihub. Acesso em: 28 mar. 2018.

OLIVEIRA, Daliana Damaceno Gil De. Implantação integrada de infraestruturas de transportes-caso do Rodoanel e Ferroanel no trecho norte, em São Paulo. 2014. [s.n.], 
Campinas,

2014

Disponível

em: http://repositorio.unicamp.br/jspui/handle/REPOSIP/258372. Acesso em: 16 dez. 2020.

ORTOLANO, Leonard; SHEPHERD, Anne. Environmental Impact Assessment: challenges and opportunities. Impact Assessment, [S. l.], v. 13, n. 1, p. 3-30, 1995. DOI: 10.1080/07349165.1995.9726076.

Disponível

em: http://www.tandfonline.com/doi/abs/10.1080/07349165.1995.9726076. Acesso em: 2 jul. 2018.

PALERM, JUAN R. Public participation in environmental decision making: examining the aarhus convention. Journal of Environmental Assessment Policy and Management, [S. l.], v. 01, n. 02, p. 229-244, 1999. DOI: 10.1142/s146433329900017x.

PETTS, Judith. Handbook of Environmental Impact Assessment. Handbook o ed. [s.1.] : John Wiley and Sons, 1999. Disponível em: https://books.google.com.br/books?hl=pt-

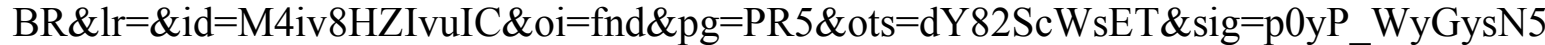
khjOX5RHB79rZ60\# $\mathrm{v}=$ onepage $\& \mathrm{q}=$ public participation $\& \mathrm{f}=$ false. Acesso em: 10 nov. 2020.

PETTS, Judith. Barriers to Deliberative Participation in EIA: Learning from Waste Policies, Plans and Projects. Journal of Environmental Assessment Policy and Management, [S. l.J, v. 05, n. 03, p. 269-293, 2003. DOI: 10.1142/S1464333203001358. Disponível em: http://www.worldscientific.com/doi/abs/10.1142/S1464333203001358. Acesso em: 2 jul. 2018.

PINHO, Paulo; MCCALLUM, Sabine; CRUZ, Sara Santos. A critical appraisal of EIA screening practice in EU Member in states. Impact Assessment and Project Appraisal, [S. l.], v. 28, n. 2, p. 91-107, 2010. DOI: 10.3152/146155110X498799. Disponível em: https://www.tandfonline.com/doi/abs/10.3152/146155110X498799. Acesso em: 23 out. 2020.

PINSONNEAULT, Alain; KRAEMER, Kenneth L. Survey research methodology in management information systems: An assessment. Journal of Management Information Systems, [S. l.], v. 10, n. 2, p. 75-105, 1993. DOI: 10.1080/07421222.1993.11518001.

ALMEIDA, Maria Rita Raimundo e; MONTAÑO, Marcelo. Benchmarking na avaliação de impacto ambiental: o sistema mineiro frente às melhores práticas internacionais. Sociedade \& Natureza, [S. l.], v. 27, n. 1, p. 81-96, 2015. DOI: 10.1590/1982-451320150106.

RICHARDSON, Tim; DUSIK, Jiri; JINDROVA, Pavla. Parallel public participation: An answer to inertia in decision-making. Environmental Impact Assessment Review, [S. l.], v. 18, n. 3, p. 201-216, 1998. DOI: 10.1016/S0195-9255(98)00007-9.

SÁNCHEZ, Luis E. Development of Environmental Impact Assessment in Brazil. [s.l: s.n.]. Disponível em: https://www.researchgate.net/publication/260991255_Development_of_Environmental_Im pact_Assessment_in_Brazil.

SÁNCHEZ, Luis E.; SILVA-SÁNCHEZ, Solange S. Tiering strategic environmental assessment and project environmental impact assessment in highway planning in São Paulo, Brazil. Environmental Impact Assessment Review, [S. l.], v. 28, n. 7, p. 515-522, 2008. DOI: 10.1016/j.eiar.2008.02.001.

SÁNCHEZ, Luis Enrique. Avaliação de Impacto Ambiental: Conceitos e Métodos. 2d. ed. São Paulo: Oficina de textos, 2013.

SÃO PAULO. Lei No 9.509, de 20 de março de 1997. Dispõe sobre a Política Estadual do Meio Ambiente, seus fins e mecanismos de formulação e aplicação. São Paulo, SP, 1997. 
SÃO PAULO. Infraestrutura e meio ambiente. CONSEMA. O conselho. Disponível em: https://www.infraestruturameioambiente.sp.gov.br/consema/. Acesso em: fevereiro, 2021.

SHEPHERD, Anne; BOWLER, Christi. Beyond the requirements: Improving public participation in EIA. Journal of Environmental Planning and Management, [S. l.], v. 40, n. 6, p. 725-738, 1997. DOI: 10.1080/09640569711877.

SIMPSON, Nicholas Philip; BASTA, Claudia. Sufficiently capable for effective participation in environmental impact assessment? Environmental Impact Assessment Review, [S. l.], v. 70, p. 57-70, 2018. DOI: 10.1016/j.eiar.2018.03.004.

SMA. Resolução SMA N 49, de 28 de setembro de 2004. Dispõe sobre procedimentos para o licenciamento ambiental no âmbito da Secretaria do Meio Ambiente (Revogada). São Paulo, SP, 2004a.

SMA. Resolução SMA No 54, de 30 de novembro de 2004. Dispõe sobre procedimentos para o licenciamento ambiental no âmbito da Secretaria do Meio Ambiente. São Paulo, SP, 2004b.

SMA. Resolução SMA n 49, de 28 de maio de 2014. Dispõe sobre os procedimentos para licenciamento ambiental com avaliação de impacto ambiental, no âmbito da Companhia Ambiental do Estado de São Paulo - CETESB. São Paulo, SP, 2014.

SNELL, Tim; COWELL, Richard. Scoping in environmental impact assessment: Balancing precaution and efficiency? Environmental Impact Assessment Review, [S. l.], v. 26, n. 4, p. 359-376, 2006. DOI: 10.1016/j.eiar.2005.06.003.

TANG, Shui Yan; TANG, Ching Ping; LO, Carlos Wing Hung. Public participation and Environmental Impact Assessment in Mainland China and Taiwan: Political foundations of environmental management. Journal of Development Studies, [S. l.], v. 41, n. 1, p. 1-32, 2005. DOI: 10.1080/00220380420000276554. Disponível em: https://www.tandfonline.com/doi/abs/10.1080/00220380420000276554. Acesso em: 8 set. 2020.

TENNØY, Aud; KVÆRNER, Jens; GJERSTAD, Karl Idar. Uncertainty in environmental impact assessment predictions: The need for better communication and more transparency. Impact Assessment and Project Appraisal, [S. l.], v. 24, n. 1, p. 45-56, 2006. DOI: 10.3152/147154606781765345.

UNECE. Convention on Access to Information, Public Participation in Decision-Making and Access to Justice in Environmental Matters. Aarhus Convention, Dinamarca, 1998. Disponível em: https://unece.org/DAM/env/pp/documents/cep43e.pdf. Acesso em: maio. 2020.

UNEP. Report of the United Nations Conference on Environment and Development. United Nations Environment Programme. Rio de Janeiro, 1992. Diponível em: https://www.un.org/en/development/desa/population/migration/generalassembly/docs/globa lcompact/A_CONF.151_26_Vol.I_Declaration.pdf. Acesso em: maio.2020.

VANCLAY, Frank. Project-induced displacement and resettlement: from impoverishment risks to an opportunity for development? Impact Assessment and Project Appraisal, [S. l.], v. 35, n. 1, p. 3-21, 2017. DOI: 10.1080/14615517.2017.1278671. Disponível em: https://www.tandfonline.com/doi/full/10.1080/14615517.2017.1278671.

WESTON, Joe. Screening for environmental impact assessment projects in England: What screening? Impact Assessment and Project Appraisal, [S. l.], v. 29, n. 2, p. 90-98, 2011. DOI: $\quad 10.3152 / 146155111 X 12913679730593 . \quad$ Disponível em: 
https://www.tandfonline.com/doi/abs/10.3152/146155111X12913679730593. Acesso em: 23 out. 2020.

WIKLUND, Hans. In search of arenas for democratic deliberation: a Habermasian review of environmental assessment. Impact Assessment and Project Appraisal, [S. l.], v. 23, n. 4, p. 281-292, 2005. DOI: 10.3152/147154605781765391. Disponível em: http://www.tandfonline.com/doi/abs/10.3152/147154605781765391. Acesso em: 2 jul. 2018.

WIKLUND, Hans. Why high participatory ideals fail in practice: A bottom-up approach to public nonparticipation in EIA. In: JOURNAL OF ENVIRONMENTAL ASSESSMENT POLICY AND MANAGEMENT 2011, Anais [...]. : Imperial College Press , 2011. p. 159178. DOI: 10.1142/S1464333211003833. Disponível em: www.worldscientific.com. Acesso em: 10 nov. 2020.

WOOD, Christopher. ENVIRONMENTAL IMPACT ASSESSMENT IN DEVELOPING COUNTRIES: AN OVERVIEW. In: CONFERENCE ON NEW DIRECTIONS IN IMPACT ASSESSMENT FOR DEVELOPMENT: METHODS AND PRACTICE 2003, Manchester. Anais [...]. Manchester p. 1-28.

WOOD, Graham; BECKER, Julia. Discretionary judgement in local planning authority decision making: Screening development proposals for environmental impact assessment. Journal of Environmental Planning and Management, [S. l.], v. 48, n. 3, p. 349-371, 2005. DOI: $10.1080 / 09640560500067467$.

WOOD, Graham; GLASSON, John; BECKER, Julia. EIA scoping in England and Wales: Practitioner approaches, perspectives and constraints. Environmental Impact Assessment Review, [S. l.], v. 26, n. 3, p. 221-241, 2006. DOI: 10.1016/j.eiar.2005.02.001.

WU, Jiannan; XU, Mengmeng; ZHANG, Pan. The impacts of governmental performance assessment policy and citizen participation on improving environmental performance across Chinese provinces. Journal of Cleaner Production, [S. l.], v. 184, p. 227-238, 2018. DOI: 10.1016/J.JCLEPRO.2018.02.056. Disponível em: https://www.sciencedirect.com/science/article/pii/S0959652618303627. Acesso em: 30 abr. 2018. 


\section{APÊNDICE A - Roteiro da entrevista semiestruturada}

1. O que você acha do processo de licenciamento ambiental com AIA do estado de SP?

2. O que você entende por participação pública?

3. Você acha que a participação no processo de AIA é importante? Por quê?

4. Você participou do caso do licenciamento ambiental do Rodoanel?
a. Por quê você participou?
b. Em que etapa do processo?
c. De que maneira você participou?
d. Você acha que suas demandas foram ouvidas?
e. Elas foram incorporadas nos projetos?
f. Você gostou de participar?
g. Participaria de novo?
h. Quais foram as dificuldades?

5. O que você sugere de melhoria para a participação no processo de AIA como um todo? 
ANEXO A - Termo de Consentimento Livre e Esclarecido (TCLE) 


\section{UNIVERSIDADE DE SÃO PAULO \\ ESCOLA DE ENGENHARIA DE SÃO CARLOS (EESC) \\ Pós-Graduação em Ciências da Engenharia Ambiental}

\section{TERMO DE CONSENTIMENTO LIVRE E ESCLARECIDO (TCLE)}

(Resolução 466/2012 do CNS)

Eu, Cynthia Akemi Anno Franco, estudante do Programa de Pós-Graduação em Ciências da Engenharia Ambiental da Escola de Engenharia de São Carlos (EESC/USP) o(a) convido a participar da pesquisa "Participação Pública na Avaliação de Impacto Ambiental de empreendimentos do estado de São Paulo" orientada pela Prof. ${ }^{\text {a }}$ Dr. ${ }^{\text {a }}$ Maria Rita Raimundo e Almeida.

O trabalho tem por objetivo identificar os mecanismos que tendem a favorecer a participação pública no processo de Avaliação de Impacto Ambiental (AIA) de empreendimentos no Estado de São Paulo. Para cumprir com este objetivo, a metodologia desta pesquisa consiste em: 1) Revisão da bibliografia para entender a participação do público e a prática no processo de AIA do estado de São Paulo; 2) Escolha do estudo de caso; 3) Análise do conteúdo dos processos selecionados referentes ao estudo de caso escolhido; 4) Entrevistas semiestruturada com as partes envolvidas no estudo de caso; e 5) Realização de uma lista de controle para avaliação da participação pública no caso escolhido. Com a realização desta pesquisa, espera-se compreender quais estratégias de participação foram utilizadas pelas partes interessadas.

O estudo de caso selecionado foi o do Rodoanel Mário Covas. A partir da definição do caso, os processos referentes ao licenciamento ambiental dos Trechos Norte, Sul, Leste e Oeste do Rodoanel foram analisados no órgão ambiental.

Você foi selecionado(a) por ter sido identificado como uma das partes interessadas no processo de licenciamento ambiental do Rodoanel de São Paulo-SP. Sua participação na pesquisa consiste em conceder uma entrevista individual que será agendada previamente e ocorrerá via telefone ou presencialmente. No caso de a entrevista ser realizada presencialmente, a pesquisadora se deslocará até o local definido, arcando com os custos decorrentes deste deslocamento e registrará a coleta de informações via gravação de áudio, se assim for autorizada. No caso de entrevista por telefone, os áudios serão gravados, se assim for autorizada. Estes dados serão utilizados para uso exclusivamente científico-acadêmico. 
Para a realização da entrevista, estruturamos um roteiro de perguntas condutoras (ANEXO 1). As respostas irão auxiliar a embasar de forma conceitual esta pesquisa, bem como a condução das análises e considerações do trabalho.

As perguntas não serão invasivas à intimidade dos participantes, entretanto, esclareço que a participação na pesquisa pode gerar estresse e desconforto como resultado da exposição de opiniões sobre deficiências ou problemas associados à participação do público no processo de licenciamento ambiental, que em alguns casos poderá implicar riscos à posição política ou profissional por transparecer irregularidades institucionais do local de trabalho dos participantes.

Diante dessas situações, os participantes terão garantidas pausas nas entrevistas, liberdade de solicitar esclarecimentos e o direito de não responder as perguntas quando a considerarem constrangedoras, podendo interromper a entrevista a qualquer momento. Serão retomados nessa situação os objetivos a que esse trabalho se propõe e os possíveis benefícios que a pesquisa possa trazer. Em caso de encerramento das entrevistas por qualquer fator descrito acima, os pesquisadores encarregados deste trabalho se responsabilizam por danos ao participante comprovadamente causados pela participação na pesquisa.

Salientamos que sua participação auxiliará na obtenção de dados que contribuirá com a produção do conhecimento acadêmico sobre o tema. Sua participação também trará benefícios aos diferentes grupos de atores entrevistados, os quais poderão compreender e incorporar boas práticas de participação pública no processo de licenciamento ambiental de acordo com sua realidade. Os resultados dessa pesquisa serão divulgados para a sociedade fazendo uso de feedback aos participantes da entrevista, proporcionando mais informações para embasar discussões para a área ambiental e inspirar melhorias operacionais sobre envolver o público durante o processo de licenciamento ambiental.

Sua participação é voluntária e não haverá compensação em dinheiro por ela. A qualquer momento o (a) senhor (a) pode desistir de participar e retirar seu consentimento sem nenhuma implicação legal ou penalização em dinheiro. Sua recusa ou desistência não lhe trará nenhum prejuízo profissional, seja em sua relação ao pesquisador, à Instituição em que trabalha ou à Escola de Engenharia de São Carlos (EESC/USP).

Sua identidade será preservada por meio da utilização de nome fictício ou sigla, sendo assegurado o sigilo sobre sua participação em todas as etapas do estudo. Caso 
haja menção a nomes, a eles serão atribuídas letras, com garantia de anonimato nos resultados e publicações, impossibilitando sua identificação. Somente será divulgada a qual parte interessada do processo de licenciamento ambiental do Rodoanel o participante pertence, sem divulgação da Razão Social ou nome fantasia da empresa. Sendo identificados como: empresas de consultoria, órgão ambiental, ONGs, conselhos, instituições públicas ou associação de bairro.

Solicito sua autorização para gravação em áudio da entrevista. As gravações realizadas durante a entrevista semiestruturada serão transcritas pela pesquisadora, garantindo que se mantenha a mais fidedigna possível. Depois de transcrita será apresentada aos participantes para validação das informações.

Todas as despesas com o transporte e a alimentação decorrentes da sua participação na pesquisa, quando for o caso, serão ressarcidas no dia da coleta. Você terá direito a indenização por qualquer tipo de dano resultante da sua participação na pesquisa.

Você receberá uma via deste termo, rubricada em todas as páginas por você e pelo pesquisador, onde consta o telefone e o endereço do pesquisador principal. Você poderá tirar suas dúvidas sobre o projeto e sua participação agora ou a qualquer momento. 
Declaro que entendi os objetivos, riscos e benefícios de minha participação na pesquisa e concordo em participar. O pesquisador me informou que o TCLE está de acordo com as exigências da Resolução no 466 de 12 de dezembro de 2012 e o projeto foi aprovado pelo Comitê de Ética em Pesquisa em Seres Humanos da UFSCar que funciona na Pró-Reitoria de Pós-Graduação e Pesquisa da Universidade Federal de São Carlos, localizada na Rodovia Washington Luiz, Km. 235 - Caixa Postal 676 - CEP 13.565-905 - São Carlos - SP - Brasil. Fone (16) 33518110. Endereço eletrônico: cephumanos@ufscar.br

Endereço para contato ( 24 horas por dia e sete dias por semana):

Pesquisador Responsável: Cynthia Akemi Anno Franco

Endereço: Av. João Dagnone, no 1.100, Jardim Santa Angelina (Escola de Engenharia de São Carlos, Departamento de Hidráulica e Saneamento), São Carlos - SP

Contato telefônico: (016) 99777-1827

e-mail: cynthia.franco@usp.br

Orientadora: Prof. ${ }^{\text {a }}$ Dr. ${ }^{\text {a }}$ Maria Rita Raimundo e Almeida

Contato telefônico: (035) 3629-1724

e-mail: maria.rita.ralmeida@gmail.com

Local e data:

Cynthia Akemi Anno Franco

Nome do Pesquisador

Assinatura do Pesquisador

Nome do Participante

Assinatura do Participante 